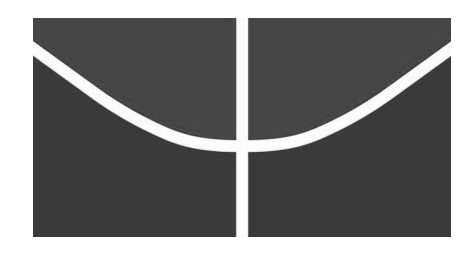
UNIVERSIDADE DE BRASÍLIA
Faculdade de Direito

Programa de Pós-graduação em Direito

Jules Michelet Pereira Queiroz e Silva

\title{
TRIBUTAÇÃO DA ENERGIA: aspectos tributários da integração energética na América do Sul
}


Jules Michelet Pereira Queiroz e Silva

TRIBUTAÇÃO DA ENERGIA: aspectos tributários da integração energética na América do Sul

Dissertação apresentada à Faculdade de Direito da Universidade de Brasília como requisito parcial para obtenção do grau de Mestre em Direito, Estado e Constituição.

Orientador: Professor Dr. Valcir Gassen 


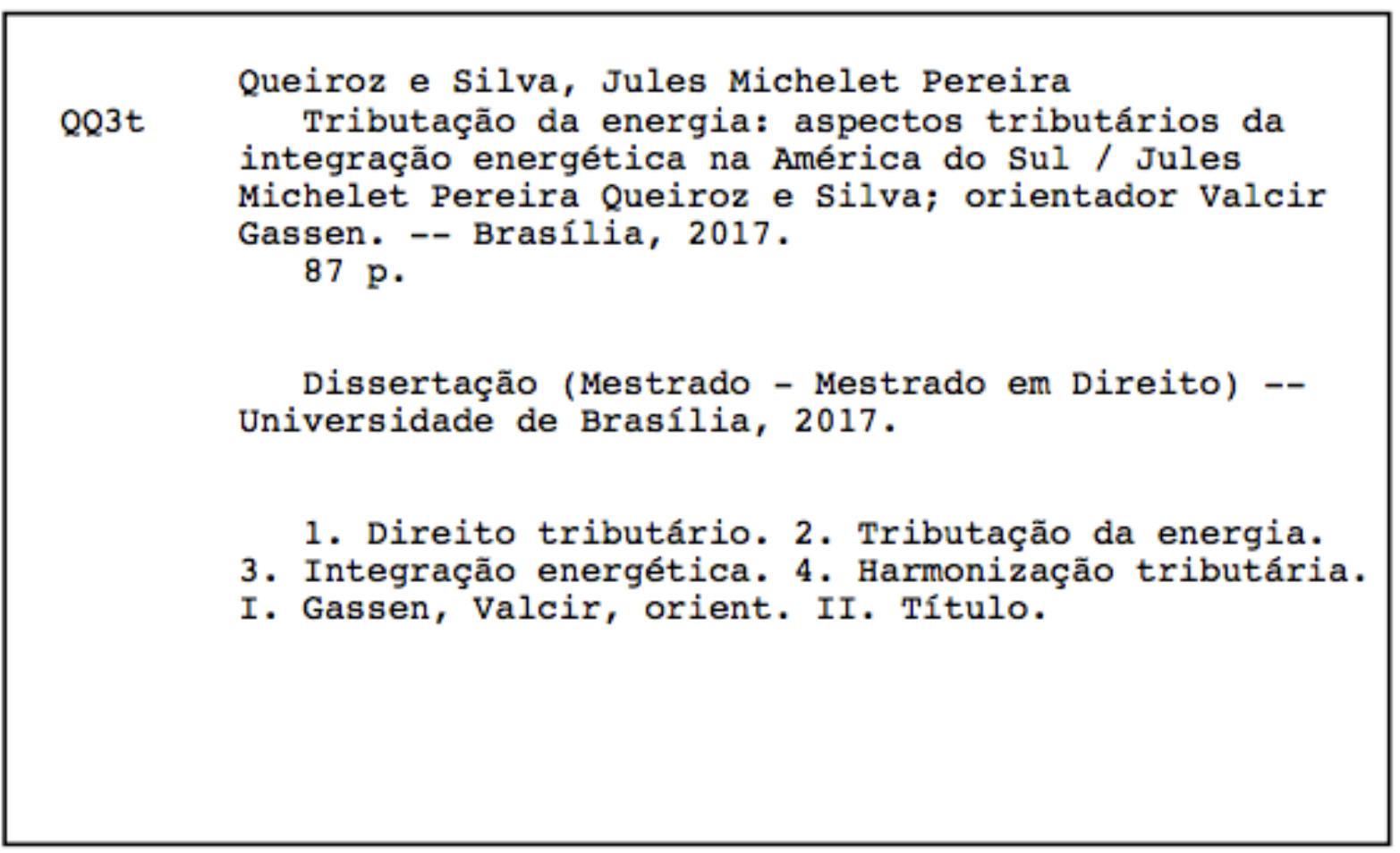


UNIVERSIDADE DE BRASÍLIA

Faculdade de Direito

Programa de Pós-graduação em Direito

Dissertação apresentada à Faculdade de Direito da Universidade de Brasília como requisito parcial para obtenção do grau de Mestre em Direito, Estado e Constituição.

\section{TRIBUTAÇÃO DA ENERGIA: ASPECTOS TRIBUTÁRIOS DA INTEGRAÇÃO ENERGÉTICA NA AMÉRICA DO SUL}

Jules Michelet Pereira Queiroz e Silva

Aprovado por:

Prof. Dr. Valcir Gassen (Professor Orientador)

Prof. Dr. Luiz Alberto Gurgel de Faria (UnB)

Prof. Dr. Marcos Aurélio Pereira Valadão (UCB)

Prof. Dr. Antônio Moura Borges (Suplente)

Brasília/DF， de de 2017. 


\section{AGRADECIMENTOS}

Agradeço em primeiro lugar à minha esposa, Athena, pela paciência com que aguentou o processo desta dissertação, além dos constantes 'insights' psicológicos.

Agradeço ao professor Valcir Gassen, paradigma do que é ser um professor, pela orientação sempre atenciosa e cuidadosa.

Agradeço à minha família pelo apoio $e$ reconhecimento constantes.

Agradeço aos colegas da Consultoria Legislativa e da Procuradoria-Geral da Fazenda Nacional pelas críticas - às vezes mais, às vezes menos - ácidas, mas sempre construtivas, ao processo de pesquisa que foi este trabalho.

Agradeço aos colegas do escritório Queiroz, Barbosa e Bielschowsky Advocacia pelo encorajamento - e exigência - de constante aprimoramento.

Por fim, mas não menos importante, agradeço a Deus pelos desafios que põe no nosso caminho e pela coragem que nos dá para enfrenta-los. 
"You will soon be able to tax it."

Michael Faraday para William Gladstone, Primeiro-Ministro britânico do Século XIX, sobre o futuro uso da eletricidade.

"O valor de uma coisa às vezes não está no que se consegue com ela, mas no que se paga por ela-quanto ela nos custa."

Friedrich Nietzsche. 


\section{RESUMO}

O trabalho discorre sobre os óbices tributários à integração energética da América do Sul e propõe soluções no âmbito da legislação brasileira para superar esses problemas. A pesquisa tem por objetivos gerais analisar as diferentes modalidades de tributação da energia nos sistemas tributários selecionados da América do Sul e propor alterações legislativas no sistema tributário brasileiro que promovam a harmonização do mesmo com os demais sistemas tributários da região. São objetivos específicos do trabalho detectar as discrepâncias entre os sistemas tributários selecionados que constituem óbice à integração em matéria de energia; analisar peculiaridades do mercado de geração, transmissão e distribuição de energia que afetem o processo de harmonização tributária entre os Estados selecionados; indicar métodos de harmonização adequados às etapas e peculiaridades do mercado de geração e fornecimento de energia; analisar a aplicação dos critérios de destino e origem na tributação da energia de modo a equilibrar equidade e eficiência; propor alterações legislativas no sistema brasileiro de modo a garantir a neutralidade fiscal sobre a energia elétrica e o intercâmbio energético eficiente entre países da região. Como marco teórico, utiliza a literatura tributária em matéria de tributação do consumo, integração econômica regional e harmonização legislativa em matéria tributária. Conclui pela necessidade de unificação e centralização da tributação geral sobre o consumo no Brasil e pela manutenção, no caso da tributação de produtos de energia, do critério de destino como definidor de competência na tributação de operações internacionais.

Palavras-chave: Tributação da energia. Tributação do consumo. Harmonização tributária. Integração energética. 


\begin{abstract}
The dissertation discusses the tax obstacles to South American energy integration and proposes solutions under Brazilian legislation to overcome these problems. The general objectives of the research are to analyze the different models of energy taxation in the selected tax systems of South America and to propose legislative changes in the Brazilian tax system that could promote it's the harmonization in relation to the other tax systems of the region. The specific objectives of the dissertation are to detect the discrepancies between the selected tax systems that are an obstacle to energy integration; analyze peculiarities of the generation, transmission and distribution market that affect the process of tax harmonization between the selected States; indicate appropriate methods of harmonization to the stages and peculiarities of the energy generation and supply market; check the application of destination and origin criteria in energy taxation in order to balance justice and efficiency; propose legislative changes in the Brazilian system in order to guarantee fiscal neutrality on energy and efficient energy exchange between countries of the region. As a theoretical framework, it uses the tax literature on taxation of consumption, regional economic integration and legislative harmonization in tax matters. It concludes by the need to unify and centralize the general taxation on consumption in Brazil and by maintaining, in the case of energy products taxation, the criterion of destination as a competence element in the taxation of international operations.
\end{abstract}

Keywords: Energy taxation. Taxation of consumption. Tax harmonization. Energy integration. 


\section{LISTA DE GRÁFICOS}

Gráfico 1 - Consumo de energia per capita v. IDH..........................................................28 


\section{LISTA DE TABELAS}

Tabela 1 - Participação do ICMS sobre energia elétrica e combustíveis na arrecadação

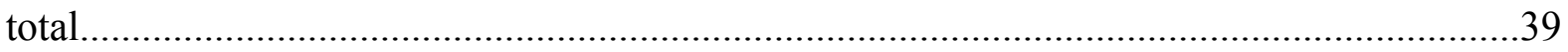

Tabela 2 - Alíquotas de ICMS-Energia Elétrica no Brasil.................................................43

Tabela 3 - Alíquotas de ICMS-Combustíveis no Brasil.......................................................45

Tabela 4 - Tributos especiais sobre o consumo de energia na América do Sul......................67 


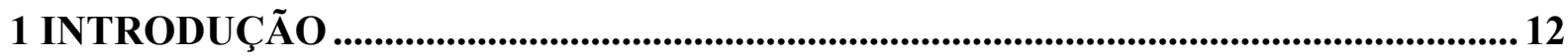

2 A INTEGRAÇÃO ENERGÉTICA …...................................................................... 17

2.1 CONCEITO E PROCESSOS HISTÓRICOS DE INTEGRAÇÃO ENERGÉTICA NA EUROPA E AMÉRICA DO SUL ................................................................................17

2.2 CONSEQUÊNCIAS ECONÔMICAS DA INTEGRAÇÃO ENERGÉTICA ......................25

2.3 ÓBICES À INTEGRAÇÃO ENERGÉTICA.................................................................... 28

3 TRIBUTAÇÃO E PROCESSOS JURÍDICOS DE INTEGRAÇÃO ECONÔMICA NA AMÉRICA DO SUL ...............................................................................................................30

3.1 BRASIL .................................................................................................................... 38

3.2 ARGENTINA …….................................................................................................... 49

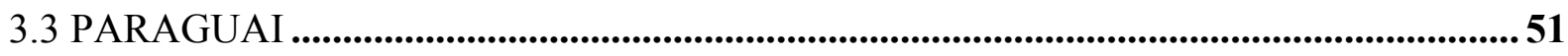

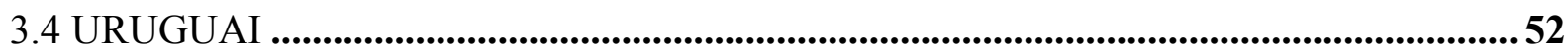

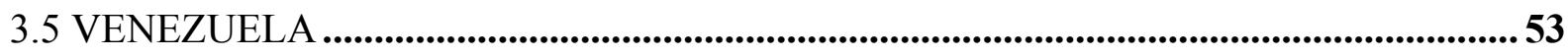

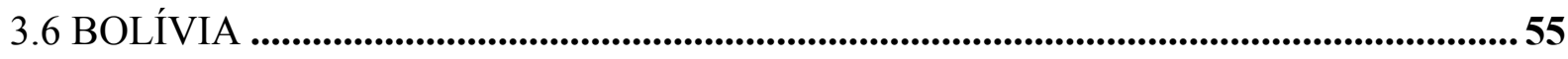

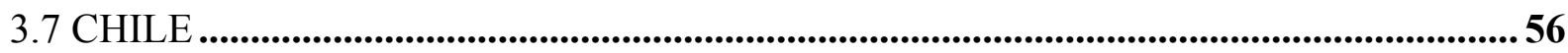

4 CONSTATAÇÕES SOBRE A TRIBUTAÇÃO DA ENERGIA NA AMÉRICA DO SUL E SEUS REFLEXOS NA INTEGRAÇÃO ENERGÉTICA..........................................58

4.1 A MÚLTIPLA INCIDÊNCIA DE TRIBUTOS GERAIS SOBRE O CONSUMO NO

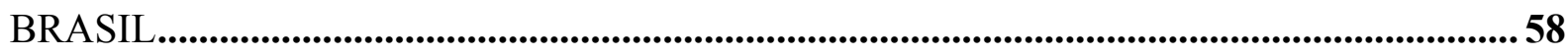

4.2 COMPETÊNCIA DOS ESTADOS-MEMBROS PARA TRIBUTAR A ENERGIA........60

4.3 OS CRITÉRIOS DE ORIGEM E DESTINO NA TRIBUTAÇÃO DA ENERGIA ..........64

5 PROPOSTA DE ALTERAÇÕES DA LEGISLAÇÃO BRASILEIRA PARA PROMOÇÃO DA INTEGRAÇÃO ENERGÉTICA ……………………………………........ 69

5.1 UNIFICAÇÃO E CENTRALIZAÇÃO DA TRIBUTAÇÃO GERAL SOBRE O CONSUMO NO BRASIL .................................................................................................70

5.2 MANUTENÇÃO DO PRINCÍPIO DE DESTINO NA TRIBUTAÇÃO DA ENERGIA.75

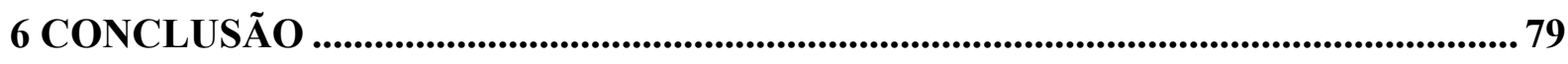

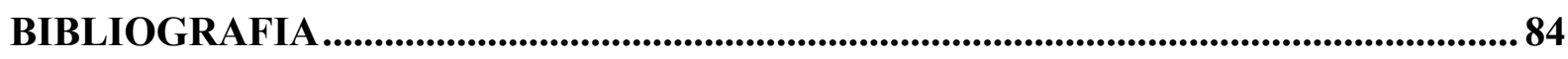




\section{INTRODUÇÃO}

$\mathrm{Na}$ era da tecnologia e da informática, a energia ${ }^{1}$ se mostra um insumo de primeira importância para todas as economias nacionais. A geração e distribuição de energia no século XXI têm se mostrado problemas comuns à maioria dos Estados nacionais preocupados no desenvolvimento de suas economias.

Nesse sentido, a crescente demanda por energia tem forçado sobremaneira os recursos naturais dos Estados, obrigando-os a rever suas matrizes energéticas e a estabelecer diretrizes regulatórias mais severas sob pena de prejudicar o meio ambiente de forma irreparável.

No ano de 2014, conforme assevera reportagem do periódico britânico "The Economist", o Brasil enfrentou sério risco de crise energética, uma vez que as principais reservas responsáveis pelo fornecimento de energia hidráulica alcançaram $37 \%$ de sua capacidade, sendo que $80 \%$ da matriz energética nacional depende de fontes hidrelétricas ${ }^{2}$.

O enfrentamento de problemas comuns é justamente o que promove a integração regional entre Estados soberanos, não sendo diferente o caso do Mercado Comum do Sul Mercosul. Daí porque a integração energética entre os Estados-partes do Mercosul se mostra tema relevante. $\mathrm{O}$ processo de integração envolve a possibilidade de livre circulação da energia, favorecendo o intercâmbio energético e a formação de cadeias produtivas regionais.

Da perspectiva brasileira, na realidade, não apenas as relações energéticas com o Mercosul são relevantes, mas também aquelas travadas com outros países de destaque na região.

Malhães e Salomão (2007, p. 19) salientam que a integração em matéria energética envolve dificuldades de ordem geográfica e técnica. Em países como o Chile, o intercâmbio energético enfrenta a dificultosa travessia da Cordilheira dos Andes. Já entre os países do Mercosul não há barreiras geográficas consideráveis, exceto a travessia de grandes rios. Entretanto, os países do bloco enfrentam barreiras legais e regulatórias para a maior integração energética.

Uma dessas barreiras legais é o díspar regime tributário aplicado por cada um dos Estados da América do Sul ao mercado de geração e distribuição de energia. Tais barreiras

\footnotetext{
${ }^{1}$ No presente trabalho, ao se referir a "energia", o autor trata de energia elétrica, petróleo e derivados e gás natural. Essa escolha decorre da relevância econômica desses produtos no mercado de energia sul-americano. O comércio de energia de fonte termelétrica e nuclear não se mostra tão relevante como as fontes eleitas, por exemplo.

${ }^{2}$ Disponível em: http://www.economist.com/news/americas/21596530-parched-southern-summer-may-causeelectricity-crisis-rain-checked. Acessado em 25/08/2014, às 15h38min.
} 
envolvem tanto modalidades diversas de tributação quanto cargas tributárias distintas, o que afeta profundamente o custo da energia e reduz a neutralidade fiscal intra-bloco.

Outro problema é que a divergência de regimes tributários implica, por exemplo, dificuldades ao aproveitamento de créditos de tributos plurifásicos entre Estados, conflitos entre regimes de tributação do consumo e o puro e simples desestímulo tributário à interconexão de sistemas.

Com efeito, o presente trabalho visa analisar, como técnica de integração energética dos países da América do Sul, a harmonização legislativa em matéria tributária.

É evidente que a incidência tributária sobre a energia se dá de forma distinta em cada um dos países da América do Sul. Isso implica custos energéticos diferentes para cada um dos países, favorecendo a instalação de empreendimentos nas nações de menor carga tributária sobre a energia.

Além disso, a divergência entre sistemas tributários torna mais complexo e caro o intercâmbio energético no bloco, de modo a desestimular a formação de cadeias produtivas regionais sólidas no Mercosul e nos demais países da região, bem como a própria integração dos sistemas nacionais de geração, transmissão e distribuição de energia elétrica e de exploração e transporte de gás natural ou derivados de petróleo.

Por essa razão é que as Diretrizes de Políticas Energéticas no Mercosul ${ }^{3}$ destacam o enfrentamento da questão tributária, elencando como elementos básicos da política energética comum: o favorecimento da integração entre os mercados energéticos dos Estadospartes, com liberdade de compra e venda de energia entre as empresas de energia e livre trânsito dos energéticos, respeitando as legislações vigentes em cada país; a equivalência de tratamento tributário (impostos, taxas e gravames internos) à energia destinada aos setores produtivos tendente à harmonização das políticas fiscais aplicadas.

Observa-se que no âmbito tributário, há políticas bastante diversas na tributação da energia mesmo no Mercosul e nos demais países sul-americanos, conforme se verá no decorrer deste trabalho.

Essa divergência de tributação, embora não se mostre a única, é uma das causas relevantes para a grande disparidade no custo da energia elétrica no âmbito do Mercosul. Segundo levantamento da Federação das Indústrias do Rio de Janeiro realizado em 2011, o custo da energia elétrica para o setor industrial no Brasil (R\$329,0/MWh) é em muito

\footnotetext{
3 Resolução no 57/93 do Grupo do Mercado Comum (GMC) do Mercosul.
} 
superior ao do Uruguai ( $\mathrm{R} \$ 179,7 / \mathrm{MWh}$ ), Argentina ( $\mathrm{R} \$ 88,1 / \mathrm{MWh}$ ) e Paraguai (R\$ 84,4/MWh) (FIRJAN, 2012, p. 1).

Com a Medida Provisória $n^{\circ} 579$, de 11 de setembro de 2012, convertida na Lei $\mathrm{n}^{\mathrm{o}}$ 12.783, de 11 de janeiro de 2013, o Governo Federal brasileiro buscou uma redução no custo da geração e transmissão de energia elétrica mediante o adiantamento da renovação das concessões no setor. A perspectiva foi a redução média de $20,2 \%$ no custo da energia elétrica no país (BRASIL, 2013, p. 51), o que ainda deixa muito distante os preços da energia elétrica praticados no Brasil em relação aos observados nos demais países do Mercosul. Contudo, essa medida não enfrentou o problema tributário.

Outro ponto a destacar em matéria de harmonização tributária é que sua importância em muito decorre dos princípios jurisdicionais de soberania dos Estados e, na tributação do consumo, tais princípios envolvem a tributação por critérios de origem ou destino.

No caso de operações com energia elétrica e consumo de derivados de petróleo, observa-se uma peculiaridade em relação à tributação em geral sobre o consumo: normalmente, há uma concentração na localização dos potenciais de energia hidráulica, o que faz com que sua colocação espacial dependa mais de circunstâncias naturais do que de decisões econômicas.

Daí porque é ainda mais relevante a discussão dos critérios de origem e destino na tributação da geração de energia para evitar disparidades na arrecadação dos Estados, garantir a livre circulação de energia e a neutralidade fiscal no mercado. A análise, portanto, deve envolver considerações quanto à equidade e eficiência econômica do sistema harmonizado.

Isso posto, são objetivos gerais da pesquisa proposta: analisar as diferentes modalidades de tributação da energia nos sistemas tributários selecionados da América do Sul; propor alterações legislativas no sistema tributário brasileiro que promovam a harmonização do mesmo com os demais sistemas tributários da América do Sul.

Por outro lado, são objetivos específicos da pesquisa proposta: detectar as discrepâncias entre os sistemas tributários selecionados que constituem óbice à integração em matéria de energia; analisar peculiaridades do mercado de geração, transmissão e distribuição de energia que afetem o processo de harmonização tributária entre os Estados selecionados; indicar métodos de harmonização adequados às etapas e peculiaridades do mercado de geração e fornecimento de energia; analisar a aplicação dos critérios de destino e origem na tributação da energia de modo a equilibrar equidade e eficiência; propor alterações 
legislativas no sistema brasileiro de modo a garantir a neutralidade fiscal sobre a energia e o intercâmbio energético eficiente entre países da região.

Como hipóteses de pesquisa, elencam-se a necessidade de uniformização dos mecanismos de tributação da energia para promover a integração energética da região; necessidade de coordenação efetiva entre os princípios de origem e destino nas operações regionais com o fim de equilibrar princípios de equidade e eficiência. O teor dessas mudanças sistêmicas será enfrentado no decorrer do trabalho, em seguida à análise da legislação dos Estados pesquisados.

O presente trabalho será dividido em quatro capítulos.

O primeiro capítulo tratará do conceito de integração energética, bem como descreverá a evolução do processo na Europa e na América do Sul. É relevante a alusão ao processo histórico europeu de integração para servir de parâmetro de comparação ao processo sul-americano. Na análise deste último, por fim, serão apontados os óbices à sua evolução.

O segundo capítulo tratará do referencial teórico alusivo à coordenação e à harmonização tributárias, além da tributação do consumo, trazendo a literatura pertinente. No mesmo capítulo, será feito o estudo comparativo entre os sistemas tributários dos Estadosmembros do Mercosul - Brasil, Uruguai, Paraguai e Argentina - bem como de três países sulamericanos selecionados - Bolívia, Venezuela e Chile - quanto à tributação da energia.

A justificativa quando à análise dos Estados-membros do Mercosul é evidente, pois tratam-se de parceiros comerciais do bloco econômico regional ao qual pertence o Brasil. Por outro lado, a escolha da Bolívia diz respeito ao papel desta como exportador de gás natural para o Brasil, especialmente por intermédio do Gasoduto Brasil-Bolívia (Gasbol). A Venezuela, por sua vez, é escolhida por ser fornecedor relevante de petróleo e derivados para o Brasil. Em 2014, o Brasil importou o equivalente a US\$ 1,06 bilhão da Venezuela, sendo a maioria $(61 \%)$ de petrolíferos refinados e coque de petróleo $(11 \%)^{4}$. O Chile, por sua vez, é uma economia relevante no continente sul-americano, além de ser relevante parceiro comercial do Brasil em matéria de energia. Em 2014, o Brasil exportou US\$ 5,31 bilhões para o Chile, em sua maioria (44\%), petróleo $\mathrm{cru}^{5}$.

O terceiro capítulo analisará as informações trazidas no segundo. O capítulo discorrerá sobre as características dos diversos países pesquisados, em especial o Brasil, alusivas à tributação da energia, que impedem um eficaz processo de integração energética

\footnotetext{
${ }^{4}$ Disponível em: http://atlas.media.mit.edu/pt/visualize/tree_map/hs92/import/bra/ven/show/2014/, acessado em 11 de janeiro de 2017 , às $17 \mathrm{~h} 30 \mathrm{~min}$.

${ }^{5}$ Disponível em http://atlas.media.mit.edu/pt/visualize/tree_map/hs92/export/bra/chl/show/2014/, acessado em 11 de janeiro de 2017 , às $17 \mathrm{~h} 37 \mathrm{~min}$.
} 
entre eles. Nesse capítulo, será dada ênfase à questão da neutralidade tributária ante as divergências encontradas, bem como à análise da adoção dos princípios jurisidicionais de origem e destino.

O quarto capítulo explorará propostas de modificação da legislação tributária brasileira, com o fim de sanar as deficiências detectadas no capítulo anterior. Também, apontará os mecanismos de coordenação e harmonização tributária que se entende pertinentes ao quadro detectado.

Por fim, à guisa de conclusão, se realizará um apanhado de todas as constatações expostas e suas soluções propostas. 


\section{A INTEGRAÇÃO ENERGÉTICA}

\subsection{CONCEITO E PROCESSOS HISTÓRICOS DE INTEGRAÇÃO ENERGÉTICA NA EUROPA E AMÉRICA DO SUL}

O presente trabalho, conforme exposto, analisa um aspecto bastante particular dos processos de integração econômica: a integração dos mercados energéticos. Para tanto, é interessante destacar em primeiro lugar o conceito de "integração energética".

Pode-se dizer que a integração energética consiste no processo de interconexão estratégica das redes de energia em corredores nacionais, regionais ou internacionais que permitam, sob um âmbito normativo comum e serviços adequados, a circulação ágil e eficiente de energia dentro de determinado espaço de integração (MALHÃES, SALOMÃO, 2007, p. 3).

Neste trabalho, será abordada a integração no âmbito da energia elétrica, gás natural, petróleo e derivados. Por outro lado, não serão abordados de forma central os aspectos infraestruturais, mas sim os aspectos regulatórios, em especial tributários.

A literatura define a regulação como o conjunto de atos e medidas estatais que têm por fim garantir a observância dos princípios da ordem econômica no mercado, bem como a devida e correta prestação de serviços públicos, além do incentivo e fomento para a implementação das políticas públicas respectivas para direcionamento de cada nicho da economia (FIGUEIREDO, 2014, pp. 288-289). Em síntese, de forma ampla, pode se afirmar que a regulação busca imprimir medidas de interesse público em determinado mercado regulado.

A regulação pode envolver a correção de falhas de mercado (OCDE, 2011, p. 23), como reduzir custos de transação através de regras relacionadas a contratos; reduzir assimetria de informações; mitigar os efeitos de externalidades; e dificultar a criação de monopólios. Além disso, a regulação pode tratar de problemas distributivos, no sentido de prover uma quantidade mínima de determinados produtos e serviços essenciais aos seus cidadão. Por fim, há setores regulados em que se buscam fins mais específicos, como a manutenção de valores como a segurança e a saúde púbica.

A política tributária ${ }^{6}$, por sua vez, pode ser utilizada como um instrumento regulatório. Através dos tributos, podem ser alterados os custos de transação, de modo a

\footnotetext{
6 “A política tributária resulta da atuação dos agentes políticos, os quais, com base nas sugestões teóricas racionais e diante de outras condicionantes, decidem a respeito de um sistema tributário para o mundo real, o das
} 
induzir comportamentos desejados ou desestimular comportamentos indesejados nos agentes regulados. Além disso, a receita de determinadas espécies tributárias pode ser utiliza para atacar deficiências de mercado e externalidades negativas. É o que ocorre, por exemplo, com a espécie tributária das contribuições de intervenção no domínio econômico.

A regulação toma relevância bastante especial no setor energético em razão de suas especificidades. Há o problema, por exemplo, do determinismo geográfico das fontes de energia: a exploração de potenciais energéticos na maioria das vezes depende mais da determinação natural de sua localização do que decisões do explorador.

No caso da energia elétrica, por exemplo, há uma concentração de potenciais de geração hidrelétrica. Segundo a ANEEL (BRASIL, 2005, p. 45), um total de 78,8\% do potencial hidrelétrico estimado brasileiro ${ }^{7}$ está concentrado na bacia do Rio Amazonas. $\mathrm{O}$ segundo maior potencial é da bacia do Rio Paraná, com 8,7\% do potencial nacional estimado.

No setor elétrico, além dessa concentração de potencial estimado, ainda há outro problema de mercado: a concentração de investimentos. A bacia do Rio Paraná tem 30,3\% do potencial inventariado ${ }^{8}$ nacional, enquanto a bacia do Amazonas tem apenas $23 \%$. Há, portanto, uma concentração de investimentos na bacia mais próxima a grandes centros industriais e populacionais - notadamente o Estado de São Paulo - em detrimento de um grande potencial estimado na Região Norte do país. Se essa proximidade por um lado pode reduzir os custos de transmissão de energia, por outro deixa em desuso grande potencial de geração.

O problema do determinismo geográfico é ainda mais intenso no setor de petróleo e gás. Além do problema do determinismo geográfico, o petróleo e o gás natural são recursos não renováveis, altamente estratégicos e sua exploração envolve o domínio de tecnologia de ponta (PITQUET, 2007, pp. 22-23). As empresas que atuam no setor o fazem de forma globalizada, organizando o espaço de maneira seletiva. As áreas produtoras funcionam como

possibilidades efetivas, resultando na construção de um 'sistema tributário histórico', expresso pela legislação." (LAGEMANN, 2012, p. 52).

${ }^{7}$ Segundo a ANEEL (BRASIL, 2005, p. 45), o potencial estimado de uma bacia hidrográfica é a soma do seu potencial remanescente e do individualizado. O potencial remanescente é o resultado de estimativa realizada em escritório, a partir de dados existentes - sem qualquer levantamento complementar - considerando-se um trecho de um curso d'água, via de regra situado na cabeceira, sem determinar o local de implantação do aproveitamento, enquanto o potencial individualizado é o resultado de estimativa realizada em escritório para um determinado local, a partir de dados existentes ou levantamentos expeditos, sem qualquer levantamento detalhado.

${ }^{8} \mathrm{O}$ potencial inventariado é o que inclui usinas em diferentes níveis de estudos - inventário, viabilidade e projeto básico - além de aproveitamentos em construção e operação (BRASIL, 2005, p. 45). Pode-se dizer, a grosso modo, que o potencial inventariado é aquele em vias de exploração ou já em exploração efetiva. 
campos de fluxos, onde se articulam sofisticadas redes de unidades industriais, portos, dutos, aeroportos, bens, pessoal e informações (PITQUET, 2007, p. 23).

É indiscutível, portanto, a relevância do Estado, sua política regulatória e tributária, na definição do desenvolvimento desses mercados energéticos em um espaço de integração.

Os processos de integração energética têm elevada importância histórica e econômica. Em um primeiro momento, pode-se notar que a integração energética foi o mote fundador da mais avançada experiência de integração regional da história: a União Europeia.

O Tratado de Paris, de 18 de abril de 1951, firmado entre França, Alemanha, Itália, Bélgica, Luxemburgo e Países Baixos, fundou a Comunidade Europeia do Carvão e do Aço (CECA). A CECA, superando rivalidades da Segunda Guerra Mundial entre França e Alemanha, objetivava, segundo o art. $2^{\circ}$ de seu trabalho constitutivo, contribuir, graças ao mercado comum do carvão e do aço, para a expansão econômica, para o aumento do emprego e para a melhoria do nível de vida. Criou-se um mercado comum que visava o livre acesso a fontes de produção, dentre elas o carvão enquanto fonte de energia.

A experiência da CECA para a Europa foi um sucesso. A produção de carbono e de aço aumentou em 75\% entre 1952 e 1960 e a produção industrial aumentou 58\% no mesmo período (GUANIPA, 2013, p. 48).

Importa destacar uma contribuição teórica relevante, contemporânea ao desenvolvimento da CECA, para a integração econômica europeia por meio da energia. Em 1955, o autor francês Pierre de Beaumont propõe um modelo de integração mediante harmonização tributária dos impostos europeus (BEAUMONT, 1955, pp. 115-118). O ponto central desse processo de harmonização seria, segundo o autor, um tributo europeu sobre a energia.

O segundo passo na integração energética da Europa se deu com o Tratado de Roma, de 25 de março de 1957. Por esse tratado, os fundadores da anterior CECA criaram a Comunidade Econômica Europeia (CEE) e a Comunidade Europeia de Energia Atômica (Euratom). Mais uma vez, fica patente que a integração econômica em geral se dá a partir de uma elevada preocupação com o combate a problemas energéticos comuns, o que descamba na integração energética.

Henry Jiménez Guanipa (2013, p. 28), salienta que apesar da importância da energia para a reconstrução econômica da Europa, os tratados em questão não desenvolveram um marco legal específico para o setor. As iniciativas da Comunidade Europeia se basearam 
na cooperação entre Estados membros e nos princípios e objetivos gerais dos tratados e das políticas setoriais comunitárias.

A harmonização da política energética da Comunidade Europeia só veio a ocorrer posteriormente a 1973 em virtude da crise do petróleo. O aumento dos preços do petróleo revelou a fragilidade e a dependência exterior do mercado energético europeu e apontou para uma necessidade de minimizar o impacto de possíveis interrupções futuras de abastecimento (NAVARRO, SUSINO apud GUANIPA, 2013, p. 50).

Em 1986 foi aprovado o Ato Único Europeu para formar um mercado comum europeu, inclusive do ponto de vista energético. Isso resultou na década seguinte na edição do Livro Verde "Por uma Política Energética da União Europeia" e um Livro Branco "Uma Política energética para a União Europeia”. A partir desse momento, a Europa passou a desenvolver uma política regulatória comum de integração energética.

No que diz respeito ao aspecto tributário da integração europeia, cabe salientar as providências comunitárias para um sistema comum de tributação do consumo com adoção do Imposto sobre Valor Agregado (IVA). A harmonização do IVA europeu passou por três fases.

A primeira se deu em 1967, com a Diretiva 67/227/CEE. Ela impunha a necessidade de estabelecimento, nos Estados-partes da Comunidade, de um tributo sobre o valor agregado plurifásico, que mais tarde passaria a ser o IVA (BASTO, 1991, p. 114). Já a Diretiva 67/228/CEE traria os princípios fundamentais de incidência do IVA europeu, como bases de incidência, contribuintes e demais elementos da norma de incidência.

A segunda fase se deu pela Diretiva 77/388/CEE. Essa diretiva criou bases de incidência uniformes, ampliando, inclusive, a base econômica de incidência do imposto. Nessa segunda fase houve a harmonização propriamente dita das regras de IVA entre os diversos Estados-partes. Nessa fase também houve a destinação de parte da receita do IVA para o financiamento dos órgãos comunitários.

Mais tarde, a Diretiva 77/388/CEE e as demais relativas ao IVA foram consolidadas na Diretiva 2006/112/CEE.

Entretanto, a harmonização nacional do IVA não era suficiente para garantir a livre circulação nas operações europeias intracomunitárias, pelo que foi necessário coordenador os princípios de origem e destino ${ }^{9}$ para a cobrança do imposto, primeiramente

\footnotetext{
${ }^{9} \mathrm{O}$ capítulo seguinte deste trabalho discorrerá de forma mais completa sobre os princípios jurisdicionais da origem e destino na tributação internacional. Contudo, apenas para ilustrar a presente discussão, em síntese o princípio de origem se dá quando o Estado do exportador tem competência para tributar as operações que destinem produtos ao exterior. No princípio de destino, ocorre o inverso, quando o Estado em que é consumido o produto (importador) tem competência para tributar a operação.
} 
por um período de transição e em seguida por um período definitivo em que se adotaria a tributação na origem (SÁNCHEZ, 1999, pp. 12-13). Esse foi o cerne da terceira fase da harmonização europeia.

Contudo, o sistema de tributação na origem (conhecido como "propostas Cockfield") não chegou a ser implementado, pois havia a necessidade de criação de uma câmara de compensação financeira entre os Estados-partes em razão das perdas com a adoção do novo princípio (SÁNCHEZ, 1999, p. 15). Em vez disso, o que ocorreu foi a adoção permanente do sistema anteriormente tido como transitório para as operações intracomunitárias.

O sistema transitório europeu pressupõe a tributação no Estado de destino, mas com eliminação de fronteiras fiscais (SÁNCHEZ, 1999, pp. 16-19). Se dá, portanto, com a isenção das operações de exportação, de modo que o Estado de origem não tributa a operação. Esta é tributada no Estado de destino, cabendo a este a receita do imposto. O que cabe salientar, contudo, é que o contribuinte no Estado de destino não será um importador que recolherá o tributo na aduana, mas o próprio comprador, que recolherá ao seu Fisco nacional. Assim, o sistema europeu passa a destacar três tipos de operações: as internas de cada Estadoparte; as intracomunitárias; e as internacionais, extracomunitárias ${ }^{10}$.

Contudo, a Europa manteve a adoção da tributação na origem nas operações entre particulares, ou seja, entre pessoas que não sejam empresas ou contribuintes habituais do imposto (DIAS, 2004, p. 33).

Também foram fixadas alíquotas mínimas de IVA, sendo a ordinária de $15 \%$ e a reduzida de 5\%, proibida a adoção de alíquotas agravadas pelos Estados-partes (DIAS, 2004, p. 32).

Outro passo relevante da União Europeia foi a edição da Diretiva n ${ }^{0}$ 2003/96/EC, que trata da harmonização legislativa dos Estados europeus acerca especificamente da tributação da energia. A norma provê níveis mínimos de tributação de produtos de energia, bem como hipóteses possíveis de isenção e concessão de incentivos fiscais, permitindo um fluxo livre de energia no bloco.

\footnotetext{
${ }^{10}$ Em sua tese de doutorado, Abel Alexandre Vilaça Dias $(2004$, p. 32) avalia de forma positiva o regime transitório do IVA: "Deste modo, sem abrir mão dos princípios e objectivos definidos nas propostas Cockfield, a Comissão opta por uma estratégia mais moderada e pragmática, concentrando a sua atenção na construção de um regime transitório que mantivesse em vigor o princípio da tributação no país de destino, abolindo ao mesmo tempo as fronteiras fiscais que lhe serviam de suporte para a arrecadação da receita (os postos aduaneiros fronteiriços)."
} 
Nota-se que a integração energética europeia ocorreu progressivamente por iniciativas multilaterais decorrentes de necessidades econômicas dos países membros. Essa constatação se torna relevante posteriormente neste trabalho a título de comparação com o quadro da América do Sul.

Nos processos globais de integração energética, ponto relevante está nas regras da Organização Mundial do Comércio (OMC), em especial o Acordo Geral sobre Tarifas e Comércio (GATT, na sigla inglesa). Além desse instrumento essencial, há de se destacar o Energy Charter Treaty (ECT).

Os acordos da OMC, em especial o GATT, são aplicáveis a todas as formas de serviços e bens, inclusive a energia. Cláusulas que podem ser destacadas são a cláusula da nação mais favorecida ${ }^{11}$ e o princípio do tratamento nacional ${ }^{12}$.

Entretanto, o regramento do GATT muitas vezes se torna insuficiente para regulamentar o comércio de energia. Por essa razão, inclusive, um dos objetivos da Rodada Doha da OMC foi revisar, melhorar e esclarecer os Artigos V, VIII e X do GATT em relação ao quadro regulatório da energia (FIESP, 2013, p. XLI). Daí a necessidade de parte dos integrantes da OMC de firmar o ECT.

O ECT é um tratado firmado entre a União Europeia, países da Europa Central e Oriental, Federação Russa ${ }^{13}$, Ásia Central e Cáucaso, bem como Austrália, Japão e Mongólia (ECS, 2004, p. 3), mas está aberto à adesão de qualquer Estado que se comprometa com seus termos. Apesar disso, cabe chamar atenção ao fato de que o ECT é uma iniciativa europeia.

Tanto o ECT quanto o Energy Charter Protocol on Energy Efficiency and Enviromental Aspects foram assinados em 1994 e entraram em vigor em 1998. O tratado e seu protocolo objetivam criar um marco regulatório internacional do mercado de energia,

\footnotetext{
${ }^{11}$ Artigo I do GATT/47: “1. Qualquer vantagem, favor, imunidade ou privilégio concedido por uma Parte Contratante em relação a um produto originário de ou destinado a qualquer outro país, será imediata e incondicionalmente estendido ao produtor similar, originário do território de cada uma das outras Partes Contratantes ou ao mesmo destinado. Este dispositivo se refere aos direitos aduaneiros e encargos de toda a natureza que gravem a importação ou a exportação, ou a elas se relacionem, aos que recaiam sobre as transferências internacionais de fundos para pagamento de importações e exportações, digam respeito ao método de arrecadação desses direitos e encargos ou ao conjunto de regulamentos ou formalidades estabelecidos em conexão com a importação e exportação bem como aos assuntos incluídos nos $\S \S 2$ e 4 do art. III.”

${ }^{12}$ Artigo III do GATT/47: "As Partes Contratantes reconhecem que os impostos e outros tributos internos, assim como leis, regulamentos e exigências relacionadas com a venda, oferta para venda, compra, transporte, distribuição ou utilização de produtos no mercado interno e as regulamentações sobre medidas quantitativas internas que exijam a mistura, a transformação ou utilização de produtos, em quantidade e proporções especificadas, não devem ser aplicados a produtos importados ou nacionais, de modo a proteger a produção nacional."

${ }^{13}$ Embora tenha assinado o ECT, em 2014, no caso Yukos, a Corte Distrital de Hague, na Holanda, reconheceu que a Rússia não preencheu os requisitos do tratado para sua ratificação. Cf.

http://www.energycharter.org/media/news/article/50-billion-arbitration-awards-against-russia-quashed/, acessado em 16 de agosto de 2016, às $18 \mathrm{~h} 37 \mathrm{~min}$.
} 
abrangendo aspectos como investimento, comércio, transmissão, eficiência energética, tributação, dentre outros. Pode-se dizer com tranquilidade que o ECT é paradigma normativo por excelência para a integração energética em âmbito mundial.

O Artigo 4 do ECT esclarece que não derroga quaisquer instrumentos da $\mathrm{OMC}$, inclusive o GATT, em relação às partes contratantes. Daí porque o GATT e o ECT são considerados complementares na regulação do comércio de energia.

Desse panorama normativo se infere que a Europa promoveu com sucesso uma integração energética internacional de grandes proporções que é estratégica na manutenção do suprimento de energia na região de forma segura e sustentável (FIESP, 2013, p. LIV-LV).

A experiência de integração energética da América do Sul se dá de forma bastante diversa da europeia.

A integração energética sul-americana se dá de forma bastante incipiente desde a década de 1960. Enquanto a iniciativa europeia decorreu da necessidade de desenvolvimento econômico e social pós-guerra, o caso sul-americano ocorreu pela urgência de inserir a região no sistema econômico internacional, que, no cenário pós-guerra, mostrava as forças dominantes das próximas décadas: por um lado os Estados Unidos e a Europa, consolidando uma aliança econômica, e por outro a União Soviética, que se distanciava estendendo sua influência no mundo, inclusive na América Latina (GUANIPA, 2013, p. 56).

Já em 1964, surgiram organizações multilaterais no continente como a Comissão de Integração Elétrica Regional (CIER) e a Associação de Assistência Recíproca Petroleira Estatal Latino-Americana. Apesar disso, a evolução posterior da integração sul-americana se deu com base em iniciativas bilaterais.

Em 1965, Brasil e Argentina firmaram uma "Declaração Conjunta sobre Política Nuclear". O texto se mostrou extremamente protocolar e trouxe apenas intenções futuras de cooperação em matéria nuclear.

Iniciativas mais concretas ocorreram, como a construção de hidrelétricas binacionais: Itaipu (Brasil-Paraguai), Yacyretá (Argentina-Paraguai) e Salto Grande (Argentina-Uruguay). Esses acordos bilaterais possibilitaram um acordo multilateral em matéria de energia: o Tratado da Bacia do Prata, que formou o Anel Hidrelétrico do Cone Sul da América. O objetivo do Tratado foi realizar conjuntamente obras que permitissem a utilização racional da Bacia do Rio da Prata.

Ainda no plano de iniciativas bilaterais, destaca-se o Gasoduto Brasil - Bolívia (Gasbol), decorrente de Protocolo de Intenções de 1991, que se tornou o maior projeto de transporte de gás da América Latina (VILLEGA, QUIROGAS apud GUANIPA, 2013, p. 58). 
Atualmente o Gasbol mede 3.150km, partindo de Santa Cruz de La Sierra, na Bolívia, e chegando ao Município de Canoas, no Rio Grande do Sul.

Brasil e Argentina firmaram em 1996 Protocolo de Entendimento em matéria de comércio de gás e energia elétrica para atender interesses de ambos os países.

No âmbito do Mercosul, embora a entidade não tenha se preocupado com a integração energética em específico nos Protocolos de Ouro Preto e Assunção, observou-se posteriormente o desenvolvimento de alguns poucos marcos nesse tema. Podem ser citados documentos como as Diretrizes Políticas Energéticas do Mercosul 57/93, Decisão 10/98, que trata do Memorando de Entendimento relativo aos intercâmbios elétricos e integração elétrica no Mercosul e a Decisão do Conselho do Mercado Comum n 49/07, referente "Plano de Ação do Mercosul para a Cooperação em Matéria de Biocombustíveis".

Deve ser feita uma distinção relevante entre o processo de integração do Mercosul e da União Europeia. Desde o Tratado de Assunção, o Mercosul escolheu não delegar poderes a órgãos de caráter supranacional, de modo que as relações entre os Estados membros se dá com base no direito internacional clássico, não no direito comunitário, como ocorre na Europa (PORTO, 2011, p. 17). Essa ausência de delegação de competências dificulta sobremaneira o processo de integração regional.

Também merece destaque a Iniciativa para Integração da Infraestrutura Regional Sul-americana (IIRSA). Trata-se de uma iniciativa que contempla mecanismos de coordenação entre os governos, instituições financeiras multilaterais (Banco Interamericano de Desenvolvimento, Banco de Desenvolvimento da América Latina e Fundo Financeiro para o Desenvolvimento da Bacia do Rio da Prata) e o setor privado com o fim de traçar e executar uma política estratégica da América do Sul e desenvolver planos e programas de investimento (UDAETA, 2006, p. 3).

A IIRSA foi criada no ano 2000 com um prazo de dez anos. Com o advento de seu termo, embora tenha sido reconhecido que contribuiu para a evolução econômica da América do Sul, não houve consenso para sua renovação. Apenas com o advento da União das Nações Sul-americanas, os objetivos da IIRSA foram assumidos pelo Conselho de Infraestrutura e Planejamento (COSIPLAN), o qual financia atualmente 88 iniciativas de infraestrutura, como a linha de transmissão $500 \mathrm{kw}$ (Itaipu-Assunção-Yacyretá) e o Gasoduto do Nordeste da Argentina (FIESP, 2013, pp. 367-377).

Apesar da existência dessas iniciativas, Guanipa (2013, p. 73) tece uma severa crítica ao processo de integração sul-americano, pois embora se constatem manifestações de vontade política desde a gênese até os últimos anos na América do Sul, tal vontade permanece 
no nível dos discursos e da assinatura de acordos, carente de instituições e regulação supranacional semelhantes ao modelo europeu.

Conceituada a integração energética e exposto o estado atual da matéria em dois processos históricos definidos, cabe agora analisar as consequências econômicas dessa integração e, em seguida, analisar os óbices peculiares à América do Sul.

\subsection{CONSEQUÊNCIAS ECONÔMICAS DA INTEGRAÇÃO ENERGÉTICA}

Os tratados internacionais sobre integração energética buscam diversos objetivos de ordem política e econômica. Da mesma forma, os agentes econômicos ${ }^{14}$ envolvidos no processo de integração têm determinadas expectativas. Neste tópico, discutiremos quais são esses objetivos e expectativas que justificariam o avanço de eventual processo de integração energética da América do Sul.

O Conselho Mundial de Energia (World Energy Council) destaca três objetivos essenciais à integração energética (WEC, 2008, p. 100): aumento da segurança energética quanto ao suprimento de energia; redução dos custos de investimento na infraestrutura de energia; e o desenvolvimento pacífico e igualitário na região.

Primeiramente, a segurança energética é abordada a partir de duas perspectivas, resumidas em estudo da Federação das Indústrias do Estado de São Paulo (2013, p. L-LI). Parte da literatura considera a segurança energética como o papel estratégico da energia na garantia da soberania nacional.

Pode-se conceituar a soberania como o atributo do poder detido pelo Estado que não reconhece outro igual a ele no campo interno e outro soberano a ele no campo externo (BASTOS, 1984, p. 9). Noutros termos, é o não reconhecimento coativo pelo Estado de sua submissão a poderes externos.

Nesse sentido, a integração energética pode oferecer um risco à soberania, pois gera interdependência energética entre Estados independentes. Pode haver situações em que o Estado detentor das fontes de energia se encontre em posição coativa em face de um Estado consumidor, minando essencialmente a soberania deste. A necessidade de integração energética, portanto, deve ser contrabalançada com a necessidade de garantia da soberania nacional no fornecimento de energia.

\footnotetext{
${ }^{14}$ Pode-se definir, para os fins deste trabalho, "agentes econômicos" como as pessoas físicas e jurídicas que exercem funções em um dado mercado. Esse conceito será retomado (de forma mais crítica) no terceiro capítulo.
} 
Essa concepção de segurança energética como elemento da soberania nacional tem levado as experiências avançadas de integração energética, como o ECT, a abarcar cláusulas garantindo a soberania nacional sobre os recursos energéticos ${ }^{15}$.

Para fins de classificação, essa abordagem será referida como soberania energética.

Outros autores abordam a segurança energética como o desafio de prover aos cidadãos acesso a energia suficiente a preços razoáveis, para uma necessidade atual ou projetada, minimizando os riscos eventuais de uma interrupção de fornecimento. Dessa perspectiva, a segurança energética é uma necessidade essencial do desenvolvimento sustentável.

A Agência Internacional de Energia (FIESP, 2013, p. LI), ciente de eventuais problemas decorrentes da necessidade de segurança energética, traçou uma série de orientações que podem contribuir para esse fim: diversificar e garantir a flexibilidade e eficiência do sistema energético; responder pronta e flexivelmente a emergências de energia; garantir que o fornecimento de energia é ambientalmente sustentável; encorajar a adoção de fontes de energia ambientalmente mais aceitáveis; melhorar a eficiência energética; contínua pesquisa e desenvolvimento de novas tecnologias em matéria de energia; manutenção de políticas para garantir a não distorção dos preços de energia; manutenção de mercados abertos e livres; encorajamento de participação de todos os países envolvidos no mercado de energia.

Outro ponto destacado em estudos do Conselho Mundial de Energia é que um dos grandes óbices ao desenvolvimento da América Latina é a ausência de infraestrutura, em especial linhas de transmissão de energia (WEC, 2008, p. 98). Segundo o Conselho, a crise energética brasileira de 2001 poderia ter sido mitigada em grande parte caso houvesse maior integração energética regional.

Essa segunda concepção será referida como segurança energética propriamente dita.

Segundo essa perspectiva, maior integração energética importaria no maior investimento em infraestrutura, o que eliminaria um gargalo para o desenvolvimento regional.

A integração, mediante a redução do protecionismo doméstico no mercado de energia, também possibilitaria a redução de custos na infraestrutura mediante ganhos de escala (WEC, 2008, p. 98).

\footnotetext{
${ }^{15}$ Nesse sentido, o Artigo 18 do ECT: "As Partes Contratantes reconhecem a soberania estatal e direitos soberanos sobre recursos energéticos. Elas reafirmam que estes devem ser exercidos de acordo com e sujeitos às regras do direito internacional." (tradução livre)
} 
Considere-se também que a integração regional aumenta o investimento estrangeiro em infraestrutura energética, posto que o acesso aos mercados, decorrente da redução do protecionismo, é preocupação central das iniciativas de integração ${ }^{16}$. O acesso aos mercados também influencia na razão entre a capacidade instalada de infraestrutura energética e a demanda nacional. Quando esta supera aquela, um mercado aberto permite importação de energia a preços razoáveis, com menor impacto ao consumidor. Quando a capacidade instalada supera a demanda interna, um mercado aberto permite fácil exportação desse excedente.

Sobre o desenvolvimento regional equilibrado, cabe salientar que especificamente na integração referente à infraestrutura de energia elétrica e ao gás natural é essencial a proximidade geográfica ${ }^{17}$. Daí porque nesses casos, o processo de integração tem um componente regional necessário, dada a natureza dos produtos envolvidos da integração.

A necessidade de um desenvolvimento equilibrado entre os países envolvidos na integração decorre da circunstância de que estados muito diferentes de desenvolvimento podem dificultar ou até mesmo inviabilizar a integração por problemas de competição. Ademais, deve-se salientar que o objetivo de qualquer processo de integração é a melhora na qualidade de vida dos cidadãos dos Estados envolvidos, de modo que o desenvolvimento regional deve ser colocado como um foco essencial da questão.

A integração energética, da perspectiva do aumento da segurança energética, é um método de erradicação da pobreza na medida em que aumenta o acesso à energia a preços razoáveis pelas populações interessadas. Conforme se observa do gráfico abaixo (UDAETA et all, 2006, p. 2), o consumo de energia per capita e o Índice de Desenvolvimento Humano (IDH) guardam uma estreita relação:

\footnotetext{
${ }^{16}$ Nesse sentido, o Artigo 3 do ECT: “As Partes Contratantes devem trabalhar para promover o acesso aos mercados internacionais em termos comerciais e para desenvolver em geral um mercado aberto e competitivo para Materiais e Produtos de Energia." (tradução livre)

${ }^{17}$ Essa necessidade não ocorre necessariamente no comércio de petróleo e derivados.
} 
Gráfico 1 - Consumo de energia per capita v. IDH

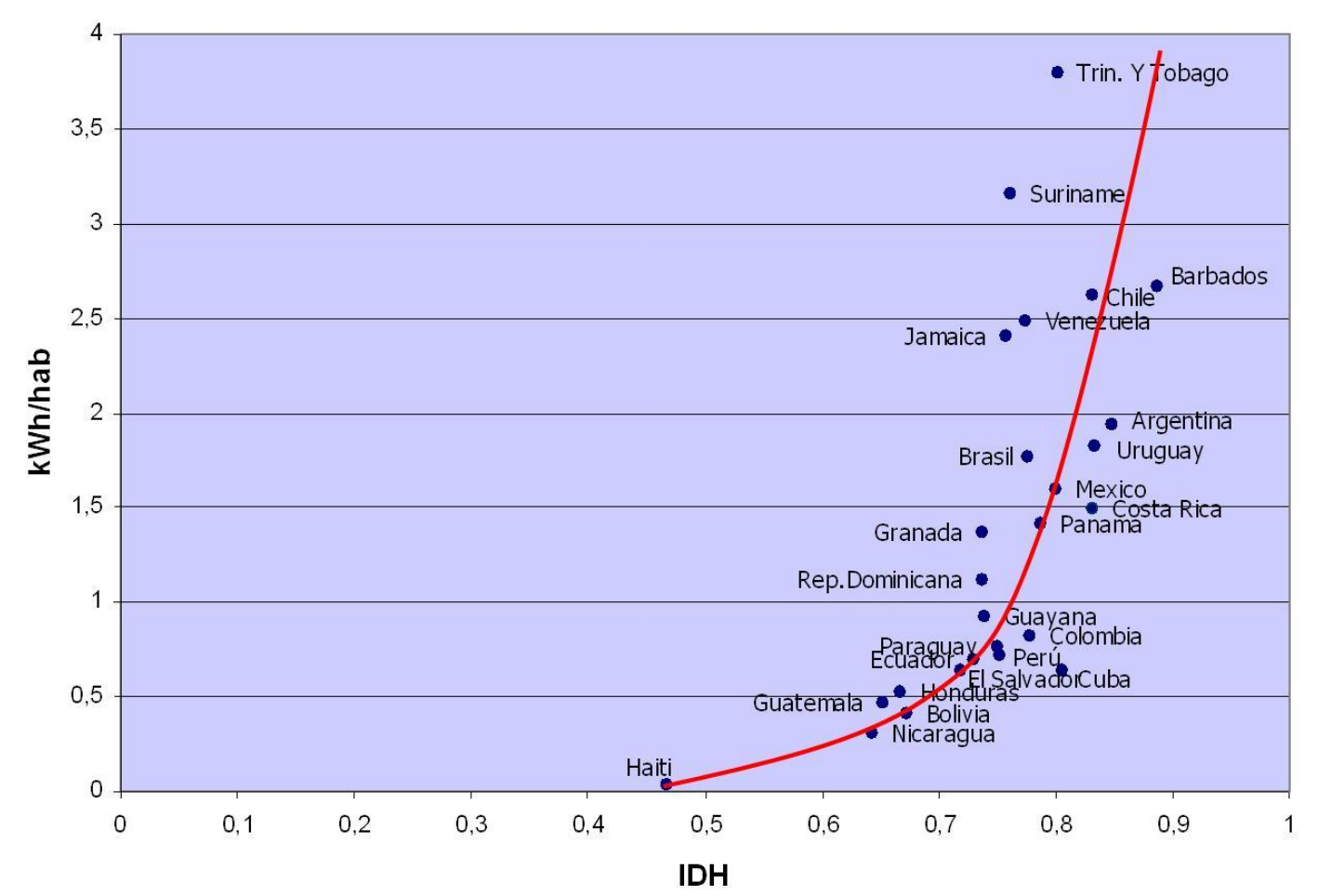

Fonte: UDAETA et all, 2006.

Conforme se observa do gráfico, o consumo de energia é superior nos países com IDH mais elevado. Nota-se que o consumo de energia, ao lado da renda por habitante, da expectativa de vida e do nível educacional, é um indicador importante no desenvolvimento humano de uma sociedade. Ora, a disponibilidade de energia a preços acessíveis implica em acesso a mecanismos úteis de desenvolvimento pessoal, como eletrodomésticos, calefação, transporte, etc. Daí se salientar a relevância da relação entre energia e desenvolvimento humano.

Considerados esses efeitos, este trabalho parte da premissa de que um avanço na integração energética é um processo desejável ao Brasil para promover o desenvolvimento econômico. A partir dessa premissa, serão analisadas as barreiras atuais para que esse processo se desenvolva, com foco no problema tributário.

\section{3 ÓBICES À INTEGRAÇÃO ENERGÉTICA}

Conforme já discutido, a integração em matéria energética envolve dificuldades de ordem geográfica e técnica. No caso dos países em estudo, à exceção do Chile, não há 
barreiras geográficas relevantes. Os óbices de natureza regulatória e tributária, por outro lado, mostram-se uma preocupação.

A infraestrutura para a integração energética de fato se mostra como um desafio de inegável relevância. Entretanto, a instalação de infraestrutura para o comércio transfronteiriço de energia demanda a superação de barreiras técnicas. Nesse sentido, Udaeta (2006, p. 18) destaca como desafios fundamentais da integração energética da América do Sul: a contenção do temor da dependência energética e da disparidade dos mercados; a desarticulação de condições que propiciem protecionismo ou privilégios; a busca da coerência regulatória regional.

Para o escopo do presente trabalho, dividem-se as barreiras técnicas em duas perspectivas. A primeira é a perspectiva do trânsito e transporte de energia elétrica, gás natural, petróleo e seus derivados. A segunda diz respeito ao aspecto regulatório concorrencial, na medida em que a disparidade concorrencial nos mercados a integrar pode se apresentar como um óbice de difícil transposição à integração energética.

Os óbices abordados no presente trabalho são especificamente os tributários. Em razão disso, ao analisar os óbices ao trânsito e transporte de energia, serão aferidas as incidências tributárias que eventualmente incidam sobre o comércio de energia nos países objeto de estudo. Feita essa análise, será avaliado se tais incidências se mostram de fato um óbice à integração energética da região.

Em seguida, será analisada a questão da influência regulatória das incidências tributárias nacionais, em especial do ponto de vista concorrencial.

Por fim, serão propostas soluções de reforma das pertinentes legislações nacionais, em especial, caso necessário, do ponto de vista da harmonização ou uniformização tributária da região. 


\section{TRIBUTAÇÃO E PROCESSOS JURÍDICOS DE INTEGRAÇÃO ECONÔMICA NA AMÉRICA DO SUL}

A integração econômica regional envolve a redução de barreiras. A natureza e amplitude dessas barreiras molda a velocidade do processo de integração.

São fases da integração econômica dos Estados a zona de livre comércio, a união aduaneira, o mercado comum e a união econômica e monetária (FERNANDES, 2001, pp. 5455). O primeiro estágio, zona de livre comércio, diz respeito à extinção de barreiras alfandegárias entre os Estados participantes do processo. Da evolução da zona de livre comércio nasce a união aduaneira, situação na qual os Estados participantes, além de extinguir barreiras alfandegárias entre si, adotam taxação idêntica para exportações e importações destinadas de ou para Estados não participantes (Tarifa Externa Comum - TEC).

Cabe destacar que a literatura aceita a existência de exceções à TEC, consistentes em listas de produtos e serviços elencadas pelos Estados-membros. Quando ocorrem essas exceções se está diante de uma união aduaneira imperfeita (FERNANDES, 2001, p. 55).

A fase seguinte de integração é o mercado comum, no qual são eliminadas as barreiras tarifárias entre os Estados-membros, adotada a TEC e iniciada a liberdade de circulação de pessoas e bens. Busca-se, nessa situação, uma coordenação econômica comum entre os diversos Estados-membros.

Por fim, há a união econômica e monetária, na qual as economias dos diversos Estados-membros são integradas por uma moeda comum. O exemplo clássico desse estágio de integração é a União Europeia.

A literatura afirma que o Mercosul atualmente se encontra no estágio de união aduaneira imperfeita (FERNANDES, 2001, p. 55) ${ }^{18}$, pois comporta uma listra extensa de exceções à TEC.

Cabe ainda salientar que além dos países membros do Mercosul, a organização conta ainda com países associados, em processo de integração ao bloco: Bolívia, Chile, Colômbia, Equador e Peru. Pelas razões já expostas neste trabalho, será destacada a situação específica do Chile e da Bolívia.

A situação da Venezuela no Mercosul é bastante peculiar. Embora viesse se comportando como membro efetivo do bloco, em 13 de setembro de 2016, os países

\footnotetext{
${ }^{18}$ Embora a afirmação de Edson Fernandes date de 2001, continua atual, pois não houve evolução no quadro normativo da entidade internacional. Inclusive, no mesmo sentido de identificar o Mercosul como união aduaneira imperfeita, cf. Saldanha (2008, p. 144).
} 
fundadores do bloco entenderam que a Venezuela não teria cumprido com os requisitos atinentes à incorporação do ordenamento jurídico do Mercosul ao seu, conforme previsto no Protocolo de Adesão da República Bolivariana da Venezuela, de modo que não poderia exercer seus direitos de membro ${ }^{19}$. Por fim, em 3 de dezembro de 2016, os países fundadores do Mercosul suspenderam a participação da Venezuela no bloco ${ }^{20}$.

A integração, conforme já discutido, depende de aproximação dos ordenamentos dos Estados que buscam o estreitamento de relações econômicas. Essa aproximação ocorre por dois processos diversos: a harmonização e a coordenação legislativas. No presente trabalho, serão considerados esses fenômenos de uma perspectiva exclusivamente tributária.

A coordenação legislativa tributária busca mecanismos de compensação e mitigação dos efeitos adversos da justaposição de ordenamentos tributários (GASSEN, 2013, p. 123). Ou seja: cada ordenamento doméstico constada os ruídos por ele gerados em contato com sistemas estrangeiros e cria mecanismos específicos para reduzir esses ruídos. Exemplos de mecanismos de coordenação tributária incluem créditos presumidos e isenções diversas. $\mathrm{O}$ ponto essencial é notar que não há mudanças estruturais entre dois ou mais sistemas para torna-los mais semelhantes e simplesmente evitar os ruídos. A coordenação, portanto, se mostra um mecanismo superficial e transitório.

A harmonização legislativa tributária, por sua vez, modifica a estrutura dos sistemas tributários em integração para torna-los mais semelhantes e evitar ruídos (GASSEN, 2013, p. 124).

A harmonização tributária envolve a resolução de dois problemas fundamentais (SALDANHA, 2008, pp. 136-137). O primeiro é a disparidade na tributação do comércio e do consumo, pois a incidência de carga tributária diversa entre os Estados a integrar pode gerar distorção nos preços e prejudicar a livre concorrência intra-bloco. O segundo é a harmonização da rentabilidade dos projetos dos agentes econômicos a depender de sua localização geográfica. É o caso, por exemplo, da disparidade na tributação da renda entre países vizinhos, que pode modificar a rentabilidade de um empreendimento e gerar uma concorrência fiscal entre Estados.

Pode-se dizer que a coordenação combate os efeitos adversos da justaposição de sistemas tributários enquanto a harmonização busca combater as fontes desses efeitos adversos.

\footnotetext{
19 Disponível em http:/g1.globo.com/mundo/noticia/2016/09/mercosul-bloqueia-presidencia-da-venezuela-eameaca-suspende-la.html, acessado em 10 de outubro de 2016 , às $18 \mathrm{~h}$.

${ }^{20}$ Disponível em http://brasil.elpais.com/brasil/2016/12/02/internacional/1480699979_812056.html, acessado em 23 de dezembro de 2016, às $11 \mathrm{~h}$.
} 
A literatura destaca como mecanismos de harmonização tributária a uniformização, a compatibilização e a instrumentação (GASSEN, 2013, p. 126). O primeiro mecanismo visa construir legislações semelhantes referentes aos aspectos estruturais, técnicos e às alíquotas de um determinado tributo, por exemplo, um tributo sobre o consumo. Noutros termos, a uniformização busca harmonizar níveis de tributação entre Estados. A compatibilização, doutro lado, busca aproximar os sistemas através de medidas que reduzam ou neutralizem os efeitos decorrentes das diferentes cargas tributárias.

É importante destacar a diferença de efeitos entre a uniformização e a compatibilização. Como a primeira importa em aproximação estrutural, fica cerceada de forma mais permanente a flexibilidade dos diferentes Estados em modificar seus sistemas internos sem prejudicar o processo de integração. Já a compatibilização, por não demandar necessariamente uma equiparação de níveis de tributação, é mais flexível e permite aos Estados alterar seus ordenamentos internos sem prejudicar o processo de integração, dadas as medidas de compatibilização já adotadas.

Para ilustrar essa divergência, pode ser apontado como mecanismo de uniformização a tributação do consumo do bloco econômico por um imposto sobre valor agregado de alíquota uniforme para todos os membros. Como medidas de compensação, por outro lado, poderiam ser apontadas reduções de alíquota para produtos específicos dentro do bloco no intuito de reduzir distorções concorrenciais.

A harmonização por compatibilização não se confunde com a coordenação tributária. Como já afirmado, a coordenação foca os efeitos das distorções. A compatibilização, forma de harmonização que é, busca mitigar as diferenças nas fontes mediante mecanismos diversos da uniformização.

A partir dessa diferença, Valcir Gassen (2013, p. 127) conclui que a harmonização tributária por uniformização é mais apropriada para as fases mais maduras do processo de integração regional.

A instrumentação, ao contrário dos outros mecanismos, não busca gerar igualdades, mas sim disparidades nos sistemas como forma de compensar diferenças estruturais de difícil conciliação.

Quanto ao processo de harmonização, além dos três mecanismos destacados, também há na literatura (SALDANHA, 2008, pp. 144-145) referência à progressão temporal. O primeiro passo da harmonização tributária é a referente a tributos sobre o comércio exterior. A adoção da TEC na união aduaneira é um exemplo desse passo. O segundo consiste na harmonização da tributação sobre o consumo. É o caso da adoção de um IVA uniforme no 
bloco. Por último, harmonizados os tributos sobre o comércio exterior e sobre o consumo, pode-se avançar para a harmonização de tributos diretos, em especial sobre a renda.

Observe-se que os dois primeiros passos buscam combater o problema da disparidade da tributação no comércio e no consumo e o terceiro passo visa neutralizar a diferença na rentabilidade dos projetos dos agentes econômicos. As fases de harmonização, portanto, visam progressivamente eliminar os problemas tributários fundamentais da integração econômica.

Por fim, à guisa de conclusão sobre a diferença entre coordenação e harmonização tributárias, aponta-se que a coordenação é adequada ao estreitamento de relações comerciais entre Estado sem o objetivo de integração. Já para a situação oposta, ou seja, para o processo de integração econômica, é mais adequado que os Estados adotem mecanismos de harmonização tributária.

Pois bem. Fixadas acima premissas teóricas acerca do papel da tributação na integração regional, cabe agora delimitar a discussão dentro do tema efetivamente objeto do presente trabalho: a tributação no processo de integração energética na América do Sul.

Conforme já aduzido, é preciso considerar que os Estados delimitados se encontram em processo de integração, na forma do Mercosul. É adequada a essa situação, portanto, a metodologia da harmonização tributária, não da coordenação. Daí se concluir, portanto, que também no que diz respeito à integração energética é aplicável a metodologia da harmonização tributária.

A fase de harmonização em que se encontra o Mercosul, sendo ele união aduaneira imperfeita, demanda uma análise de harmonização tanto da tributação do comércio exterior $^{21}$ quanto do consumo. Não será analisada a tributação direta da renda, pois ela é uma etapa posterior à resolução do problema inicial da tributação comercial e consumerista. Foge, portanto, ao recorte temático delimitado.

O foco principal será a tributação do consumo, pois a tributação da energia se enquadra nesse gênero ${ }^{22}$.

O consumo é uma das categorias em que a OCDE classifica os tributos (OCDE, 2016, p. 15), as quais consistem em: tributos sobre a renda, lucros e ganhos de capital (1000);

\footnotetext{
${ }^{21}$ Além da questão do Mercosul ainda ser uma união aduaneira imperfeita, a Bolívia e o Chile, apenas como associados, não aderiram à TEC. Assim, a análise de seus sistemas de tributação do comércio exterior é relevante para a discussão em tela.

${ }^{22}$ É certo que a tributação da renda também teria relevância nesse quadro, por exemplo, se considerada a rentabilidade dos investimentos. Fatores como a tributação dos lucros e concessão de incentivos no plano dos tributos sobre a renda (depreciação acelerada, por exemplo) são de fato relevantes. Entretanto, conforme se verá, da perspectiva dos processos de harmonização legislativa tributária (e como se viu no processo europeu), a tributação do consumo precede cronologicamente a da renda em termos de integração econômica.
} 
contribuições à seguridade social (2000); tributos sobre a folha de pagamento e força de trabalho (3000); tributos sobre a propriedade (4000); tributos sobre bens e serviços (5000). Os tributos sobre o consumo são uma modalidade de tributos sobre bens e serviços, colocados na categoria 5100, como tributos sobre produção, venda, leasing e entrega de bens e prestação de serviços.

Nesse sentido, a energia, seja sob a forma de energia elétrica, petróleo e derivados ou gás, é em geral enquadrada pelos diversos Estados no conceito de tributação do consumo.

Nos países membros da OCDE, em geral a tributação do consumo representa um terço (31\%) de suas receitas tributárias, acompanhada de perto pela tributação da renda (31\%) e contribuições à seguridade social (25\%) (OCDE, 2016, p. 16). Em contraposição a essa tendência, países subdesenvolvidos costumas tributar mais pesadamente o consumo em detrimento de outras bases. No Brasil, por exemplo, em 2015, a tributação do consumo correspondeu a quase a metade da receita tributária nacional $(49,68 \%)$, seguida pela tributação da folha de salários $(25,83 \%)$ e renda $(18,27 \%){ }^{23}$

A dependência da tributação sobre o consumo nas receitas fiscais brasileiras demonstra que o sistema tributário nacional se tornou regressivo. Enquanto a tributação da renda possibilita um efeito progressivo na tributação, a tributação do consumo, por incidir indistintamente sobre contribuintes de maior ou menor renda, tem elevado efeito regressivo. É dizer: pessoas de menor poder aquisitivo tendem a recolher, proporcionalmente, maior carga tributária que as pessoas de maior poder aquisitivo ${ }^{24}$. A dependência financeira da tributação do consumo, portanto, é uma característica de injustiça do sistema tributário brasileiro ${ }^{25}$.

Por fim, a dependência nacional da tributação do consumo também pode ser associada ao "efeito anestésico" dessa modalidade de tributação. A falta de visibilidade do tributo conduz o contribuinte de fato a suportá-lo sem se dar conta disso (BASTO, 1991, p. 28). O efeito anestésico, portanto, permite a absorção de rendas tributárias pelo Estado com menos transparência, por exemplo, do que quando se utiliza a tributação da renda.

\footnotetext{
${ }^{23}$ De acordo com dados da Receita Federal do Brasil, referentes ao exercício de 2015 (BRASIL, 2016a, p. 8). Foram considerados como tributos sobre o consumo os incidentes sobre bens e serviços.

${ }^{24}$ Para Lagemann (2012, p. 68), a alíquota tem um comportamento proporcional quando a alíquota média permanece constante em caso de variação da base de cálculo; um comportamento progressivo quando a alíquota média aumenta (diminui) com o aumento (a diminuição) da base de cálculo; e um comportamento regressivo quando a alíquota média aumenta (diminui) com a diminuição (o aumento) da base de cálculo.

${ }^{25}$ Essa mesma constatação é feita por Valcir Gassen, Pedro D’Araújo e Sandra Paulino (2013, p. 230). Constatando a opção legislativa pela dependência financeira da tributação do consumo, afirmam os autores: "Como consequência nefasta dessa escolha, acaba-se gerando uma matriz tributária altamente regressiva, o que contribui enormemente no aprofundamento do abismo social existente em nosso país, que, diga-se de passagem, é um dos mais desiguais do mundo. Em uma clara violação ao princípio da capacidade contributiva, busca-se no Brasil, por meio da tributação sobre o consumo, tributar de forma mais onerosa as camadas mais pobres da população, fazendo com que elas sustentem, em grande medida, o Estado brasileiro."
} 
Acerca da tributação do consumo, há de se diferenciar a tributação especial e a geral. A classificação de tributos sobre o consumo por esse critério leva em consideração a seletividade com que incidem, bem como a discriminação dos bens sobre o qual incidem (GASSEN, 2013, p. 97). O tributo especial é aquele em que a lei determina de forma específica os bens de consumo sobre o qual incide, enquanto o tributo geral é aquele cuja abrangência é geral e não discriminada.

Outra abordagem sobre essa distinção é a trazida por José Guilherme Xavier de Basto (1991, p. 14), segundo a qual os tributos gerais sobre o consumo incidem sobre todas ${ }^{26}$ as despesas do contribuinte, enquanto os tributos especiais sobre o consumo incidem apenas sobre despesas específicas previstas em lei.

O Imposto sobre Valor Agregado (IVA) em geral é tido pela literatura como um modelo de tributo geral sobre o consumo neutro e "amigável" ao processo de crescimento econômico (OCDE, 2016, p. 14).

Os atributos que identificam os tributos gerais sobre o consumo dos especiais, portanto, são a generalidade dos primeiros em detrimento da seletividade dos segundos. Podem, contudo, ocorrer situações limítrofes que dificultam essa classificação.

No caso brasileiro, por exemplo, o Imposto sobre Circulação de Mercadorias e Serviços de Transporte Intermunicipal e Interestadual e Telecomunicações (ICMS) normalmente é identificado como um tributo geral sobre o consumo, enquanto o Imposto sobre Produtos Industrializados (IPI) é identificado como um tributo especial sobre o consumo. Ora, de acordo com o art. $153, \S 3^{\circ}$, inciso I, da Constituição Federal ${ }^{27}$, é atributo essencial do IPI a seletividade, enquanto no caso do ICMS, o mesmo atributo é meramente acidental $^{28}$. Ocorre que, conforme se verá adiante, as alíquotas variadas do ICMS e a existência de amplas e várias hipóteses de isenção e, ainda, uma miríade de regimes especiais, o prejudicam como um tributo de incidência geral sobre o consumo. Por outro lado, a ampla base econômica do IPI, consistente em desembaraço aduaneiro, saída do estabelecimento ou

\footnotetext{
${ }^{26}$ Basto (1991, pp. 14-15), por outro lado, salienta que invariavelmente algumas despesas escaparão da tributação geral sobre o consumo. Cita notadamente despesas que por razões administrativas dificilmente serão tributadas (hard to tax items), seja porque o Fisco não consegue identifica-las a contento, seja porque os contribuintes ativamente buscam ocultá-las com sucesso. Outra categoria de despesa não tributada é aquela considerada isenta pela legislação por razões de ordem econômica e social.

27 "Art. 153. Compete à União instituir impostos sobre: [...]IV - produtos industrializados; [...]§ $3^{\circ} \mathrm{O}$ imposto previsto no inciso IV: I - será seletivo, em função da essencialidade do produto;"

28 “Art. 155. Compete aos Estados e ao Distrito Federal instituir impostos sobre: [...]II - operações relativas à circulação de mercadorias e sobre prestações de serviços de transporte interestadual e intermunicipal e de comunicação, ainda que as operações e as prestações se iniciem no exterior; [...] $2^{\circ} \mathrm{O}$ imposto previsto no inciso II atenderá ao seguinte: [...]III - poderá ser seletivo, em função da essencialidade das mercadorias e dos serviços;"
} 
arrematação de "produtos industrializados" (art. 46 do Código Tributário Nacional) torna-o pouco identificável com um imposto especial, pois incide sobre uma generalidade de bens.

A doutrina salienta uma diferença formal entre os tributos gerais e especiais sobre o consumo (BASTO, 1991, pp. 15-16). Os tributos especiais têm base de incidência expressamente definida em lei, ou seja, a lei define quais produtos devem ser atingidos. Já os tributos gerais incidem de forma residual sobre os demais bens. Como demonstrado, tal não ocorre na relação entre ICMS e IPI.

Sobre os impostos sobre o consumo especial (comumente denominados excises), cabe salientar que são seus objetivos (BASTO, 1991, p. 19): reduzir o consumo de determinado bem; dotar de progressividade um dado sistema tributário; adaptar o custo ao benefício dos serviços estatais, ou seja, endereçar externalidades negativas. A redução do consumo justifica, por exemplo, a incidência de impostos especiais sobre o consumo de cigarros e bebidas alcoólicas. A progressividade do sistema tributário, por outro lado, justifica a tributação de bens de luxo. Por fim, o combate às externalidades negativas justifica a tributação de combustíveis derivados do petróleo, pois depende do Estado o combate aos problemas ambientais e infraestruturais decorrentes do uso de combustíveis fósseis.

Nota-se, dessas colocações, que os tributos especiais sobre o consumo têm forte carga de extrafiscalidade, em contraposição aos tributos gerais, os quais são associados à ideia de neutralidade tributária.

Por neutralidade, entende-se a característica de um tributo que se analisa em não alterar os preços relativos das alternativas sobre que recaem as escolhas dos agentes econômicos (BASTO, 1991, p. 29). Os tributos gerais, portanto, devem ser uniformes e evitar influir nas decisões mercadológicas.

Em contraposição a isso, a extrafiscalidade inerente aos tributos especiais sobre o consumo, segundo Marcos Aurélio Pereira Valadão (2000, p. 231), diz respeito ao aspecto não fiscal ${ }^{29}$ do tributo, ou seja, à utilização do tributo pelo Estado para conseguir objetivos diversos da mera arrecadação, mediante oneração ou desoneração de determinadas operações para desenvolver determinado setor produtivo ou proteger-se de práticas predatórias de

\footnotetext{
${ }^{29} \mathrm{O}$ aspecto fiscal dos tributos consiste em sua função primeira, ou seja, a arrecadação de receitas derivadas para custeio do Estado e suas atividades (VALADÃO, 2000, p. 227). No caso dos tributos especiais sobre o consumo, o aspecto fiscal também é relevante, pois muitas vezes incidem sobre bens e serviços cuja demanda é pouco elástica, como os combustíveis derivados de petróleo. Em microeconomia, a elasticidade da demanda é a variação percentual na quantidade demandada em função da variação de preço do bem (VASCONCELLOS, 2006, p. 63). Como a incidência de um imposto aumenta o preço do bem, dizer que a demanda é inelástica significa dizer que ela é pouco reduzida pelo aumento no preço. Em outras palavras, a "vantagem" arrecadatória no aumento do tributo é maior que a redução do consumo que ela causa. Do ponto de vista estritamente fiscal, portanto, os tributos especiais sobre o consumo também têm relevância.
} 
exportadores (tributos com função de direitos antidumping). Como já se viu, a depender da hipótese de incidência do tributo especial, podem ser identificadas as suas finalidades extrafiscais.

Assim, em arremate, a tributação geral e a tributação especial sobre o consumo são categorias impositivas que servem de modelo teórico para o exame dos sistemas tributários sul-americanos a seguir.

No que diz respeito à tributação do consumo no contexto de comércio internacional, há de se considerar também os princípios jurisdicionais da origem e do destino. Segundo Gassen (2013, p. 64), os princípios de origem e de destino são critérios de jurisdição tributária, ou seja, elementos de conexão para definir a competência ou não dos Estados em tributar o consumo em âmbito interno ou internacional. Assim, entende-se o princípio da tributação no Estado de origem a tributação feita no Estado em que as mercadorias (no caso vertente, a energia) são produzidas. Por sua vez, entende-se como princípio da tributação no Estado de destino a tributação no Estado em que as mercadorias (ou a energia) são consumidas.

No caso da adoção do princípio da origem, portanto, pode-se afirmar que compete ao Estado exportador tributar a operação de exportação, mantendo isentas ou não tributadas as operações de importação. Por outro lado, na aplicação do princípio de destino cabe ao Estado importador tributar as operações de importação, mantendo isentas ou não tributadas as operações de exportação.

Ver-se-á em capítulo seguinte a relevância da consideração dos princípios jurisdicionais da integração econômica da América do Sul.

Quanto à delimitação de mecanismos de harmonização, trata-se de análise mais complexa. Isso porque a decisão por um ou outro mecanismo de harmonização demanda a análise efetiva das disparidades e ruídos existentes entre os sistemas dos Estados em integração. Por essa razão, a seguir, será descrita a estrutura da tributação da energia nos diversos Estados membros do Mercosul e ainda a Bolívia, Venezuela e Chile. Finalizada a descrição desses sistemas, será aberto novo capítulo para uma análise dessas disparidades e recomendação de mecanismos de harmonização voltados especificamente ao sistema brasileiro. 


\subsection{BRASIL}

A tributação da energia no Brasil, compreendida a incidência sobre energia elétrica, gás natural e combustíveis derivados de petróleo, se dá pelo imposto sobre circulação de mercadorias e serviços de comunicação e transporte intermunicipal e interestadual (ICMS), impostos de importação e exportação, contribuição para o Programa de Inclusão Social (PIS) e Programa de Formação do Patrimônio do Servidor Público (Pasep), contribuição para o financiamento da seguridade social (Cofins) e a contribuição de intervenção sobre o domínio econômico incidente sobre combustíveis (Cide-Combustíveis) ${ }^{30}$.

Rodrigo César de Oliveira Marinho (2011, pp. 259-262), entende que a obrigação prevista no art. $1^{\circ}$ da Lei $n^{\circ} 9.991$, de 2000, consiste em uma CIDE para o desenvolvimento do setor elétrico ${ }^{31}$. Contudo, ela não será acrescida a este trabalho como tributo incidente sobre o consumo de energia elétrica. Isso porque mesmo a natureza tributária dessa obrigação é questionável, pois trata de uma obrigação de investimento mínimo em pesquisa e desenvolvimento do setor elétrico. Assim, pode se afirmar que não consiste em obrigação de pagar, mas sim em obrigação de fazer, o que contraria o conceito de tributo do art. $3^{\circ}$ do Código Tributário Nacional. Na verdade, do ponto de vista do direito financeiro, mesmo a natureza de receita pública dessa obrigação pode ser questionável.

Quanto ao ICMS incidente sobre energia elétrica e combustíveis, lubrificantes e demais derivados de petróleo, houve uma modificação de competência entre as Constituições de 1967/1969 e a de 1988. No sistema de 1967/1969, havia o imposto único sobre operações relativas a combustíveis, lubrificantes e energia elétrica (art. 21, VIII, da Carta de 1967/1969 ${ }^{32}$ ) de competência da União.

Paralelamente, o consumo em geral era tributado pelo imposto sobre comércio de mercadorias (ICM). Ao criar um imposto específico e único de competência federal, a Carta de 1967/1969 tinha o objetivo de evitar que os Estados e Municípios, por meio de suas

\footnotetext{
${ }^{30}$ Não foram considerados neste estudo encargos setoriais de natureza não tributária (Conta de Desenvolvimento Energético, taxa de fiscalização, etc.) nem tributos que não incidem como o consumo.

31 "Art. $1^{\circ}$ As concessionárias e permissionárias de serviços públicos de distribuição de energia elétrica ficam obrigadas a aplicar, anualmente, o montante de, no mínimo, setenta e cinco centésimos por cento de sua receita operacional líquida em pesquisa e desenvolvimento do setor elétrico e, no mínimo, vinte e cinco centésimos por cento em programas de eficiência energética no uso final, observado o seguinte:"
}

32 “Art. 21. Compete à União instituir impôsto sôbre: VIII - produção, importação, circulação, distribuição ou consumo de lubrificantes e combustíveis líquidos ou gasosos e de energia elétrica, impôsto que incidirá uma só vez sôbre qualquer dessas operações, excluída a incidência de outro tributo sôbre elas;” 
competências tributárias, viessem a dificultar o crescimento industrial do País (CARRAZA, 2007, p. 240).

A Constituição de 1988 reverteu esse quadro, conferindo aos Estados e ao Distrito Federal a competência para tributar a energia elétrica e os combustíveis (art. 155, $\left.\S 3^{\circ}\right)^{33}$. A competência federal, entretanto, foi mantida pela incidência dos impostos de importação e exportação e pelas contribuições que ainda incidem sobre a energia. O que é relevante, contudo, é notar que houve o deslocamento da competência para tributar a energia de um imposto específico e federal sobre o consumo para um imposto geral e estadual.

Ao fazer isso, a Carta de 1988 retirou parte dos poderes da União de utilizar a tributação como instrumento de política energética ${ }^{34}$. O deslocamento de competência sobre a tributação da energia também transformou o ICMS em uma fonte essencial de receitas tributárias para os Estados e Distrito Federal, uma das bases tributárias referidas como blue chips. A participação do ICMS-Energia Elétrica e do ICMS-Combustíveis nas receitas estaduais pode ser resumida na seguinte tabela:

Tabela 1 - Participação do ICMS sobre energia elétrica e combustíveis na arrecadação total (em mil R\$)

\begin{tabular}{|c|c|c|c|c|c|c|}
\hline $\mathbf{U F}$ & $\begin{array}{l}\text { Total } \\
\text { ICMS } \\
\end{array}$ & $\begin{array}{c}\text { ICMS-Energia } \\
\text { Elétrica }\end{array}$ & $\begin{array}{c}\text { Participaçã } \\
\text { o (\%) }\end{array}$ & $\begin{array}{c}\text { ICMS- } \\
\text { Combustíveis } \\
\end{array}$ & $\begin{array}{c}\text { Participaçã } \\
\text { o (\%) }\end{array}$ & $\begin{array}{c}\text { Participação } \\
\text { Total (\%) }\end{array}$ \\
\hline NORTE & $\begin{array}{r}24.846 .9 \\
33 \\
\end{array}$ & 1.805 .892 & $\begin{array}{r}7,26806805 \\
5 \\
\end{array}$ & 5.042 .031 & $\begin{array}{r}20,2923676 \\
7 \\
\end{array}$ & 27,56043573 \\
\hline Acre & 979.178 & 86.264 & $\begin{array}{r}8,80983845 \\
6 \\
\end{array}$ & 36.732 & $\begin{array}{r}3,75130977 \\
2 \\
\end{array}$ & 12,56114823 \\
\hline Amazonas & $\begin{array}{r}7.485 .08 \\
7 \\
\end{array}$ & 200.485 & $\begin{array}{r}2,67845918 \\
2 \\
\end{array}$ & 1.033 .809 & $\begin{array}{r}13,8115829 \\
5 \\
\end{array}$ & 16,49004213 \\
\hline Pará & $\begin{array}{r}9.740 .02 \\
2 \\
\end{array}$ & 980.244 & $\begin{array}{r}10,0640840 \\
4 \\
\end{array}$ & 2.778 .964 & $\begin{array}{r}28,5313934 \\
6 \\
\end{array}$ & 38,59547751 \\
\hline Rondônia & $\begin{array}{r}3.149 .10 \\
0 \\
\end{array}$ & 229.139 & $\begin{array}{r}7,27633292 \\
1 \\
\end{array}$ & 200.515 & $\begin{array}{r}6,36737480 \\
5 \\
\end{array}$ & 13,64370773 \\
\hline Amapá & 785.715 & 47.777 & $\begin{array}{r}6,08070356 \\
3 \\
\end{array}$ & 262.833 & $\begin{array}{r}33,4514423 \\
2 \\
\end{array}$ & 39,53214588 \\
\hline Roraima & 648.603 & 7.299 & $\begin{array}{r}1,12534169 \\
6 \\
\end{array}$ & 319 & $\begin{array}{r}0,04918262 \\
8 \\
\end{array}$ & 1,174524324 \\
\hline Tocantins & $\begin{array}{r}2.059 .22 \\
8 \\
\end{array}$ & 254.684 & $\begin{array}{r}12,3679359 \\
4 \\
\end{array}$ & 728.860 & $\begin{array}{r}35,3948178 \\
6 \\
\end{array}$ & 47,76275381 \\
\hline NORDESTE & $\begin{array}{r}64.680 .9 \\
85 \\
\end{array}$ & 7.579 .734 & $\begin{array}{r}11,7186434 \\
3 \\
\end{array}$ & 13.467 .250 & $\begin{array}{r}20,8210341 \\
9 \\
\end{array}$ & 32,53967762 \\
\hline Maranhão & $\begin{array}{r}5.018 .95 \\
5\end{array}$ & 512.344 & $\begin{array}{r}10,2081807 \\
9\end{array}$ & 1.548 .623 & $\begin{array}{r}30,8554868 \\
5\end{array}$ & 41,06366764 \\
\hline Piauí & $\begin{array}{r}3.222 .82 \\
3 \\
\end{array}$ & 424.416 & $\begin{array}{r}13,1690756 \\
8 \\
\end{array}$ & 973.565 & $\begin{array}{r}30,2084538 \\
9 \\
\end{array}$ & 43,37752958 \\
\hline
\end{tabular}

\footnotetext{
${ }^{33} \mathrm{O}$ texto original da Constituição de 1988 permitia ainda a tributação de vendas a varejo de combustíveis líquidos e gasosos, exceto diesel, pelos Municípios (art. 156, inciso III). Essa possibilidade foi revogada pela Emenda Constitucional $n^{\circ} 3 / 1993$.

${ }^{34}$ Para a energia elétrica, a política energética passou a ser desenvolvida por subsídios, enquanto para os combustíveis, pela variação de alíquotas da CIDE-Combustíveis.
} 


\begin{tabular}{|c|c|c|c|c|c|c|}
\hline Ceará & $\begin{array}{r}9.859 .11 \\
3\end{array}$ & 1.263 .063 & $\begin{array}{r}12,8111220 \\
6\end{array}$ & 2.175 .131 & $\begin{array}{r}22,0621368 \\
3\end{array}$ & 34,87325888 \\
\hline $\begin{array}{l}\text { Rio Grande } \\
\text { do Norte }\end{array}$ & $\begin{array}{r}4.526 .45 \\
6 \\
\end{array}$ & 484.884 & $\begin{array}{r}10,7122216 \\
6 \\
\end{array}$ & 491.617 & $\begin{array}{r}10,8609693 \\
8\end{array}$ & 21,57319104 \\
\hline Paraíba & $\begin{array}{r}4.540 .28 \\
9 \\
\end{array}$ & 591.487 & $\begin{array}{r}13,0275187 \\
3 \\
\end{array}$ & 980.240 & 21,5898151 & 34,61733383 \\
\hline Pernambuco & $\begin{array}{r}12.840 .2 \\
28\end{array}$ & 1.480 .476 & $\begin{array}{r}11,5299821 \\
8\end{array}$ & 2.156 .755 & $\begin{array}{r}16,7968590 \\
6\end{array}$ & 28,32684124 \\
\hline Alagoas & $\begin{array}{r}3.120 .60 \\
2 \\
\end{array}$ & 353.195 & $\begin{array}{r}11,3181687 \\
4 \\
\end{array}$ & 349.170 & $\begin{array}{r}11,1891872 \\
1 \\
\end{array}$ & 22,50735595 \\
\hline Sergipe & $\begin{array}{r}2.917 .66 \\
1 \\
\end{array}$ & 298.072 & 10,2161286 & 558.090 & $\begin{array}{r}19,1279932 \\
8 \\
\end{array}$ & 29,34412188 \\
\hline Bahia & $\begin{array}{r}18.634 .8 \\
58\end{array}$ & 2.171 .796 & $\begin{array}{r}11,6544810 \\
8\end{array}$ & 4.234 .059 & $\begin{array}{r}22,7211766 \\
3\end{array}$ & 34,37565771 \\
\hline SUDESTE & $\begin{array}{r}206.444 . \\
440\end{array}$ & 22.204 .105 & $\begin{array}{r}10,7554870 \\
5\end{array}$ & 27.538 .146 & $\begin{array}{r}13,3392529 \\
2\end{array}$ & 24,09473997 \\
\hline Minas Gerais & $\begin{array}{r}37.946 .7 \\
44 \\
\end{array}$ & 4.573 .894 & $\begin{array}{r}12,0534557 \\
6 \\
\end{array}$ & 8.117 .246 & $\begin{array}{r}21,3911528 \\
2 \\
\end{array}$ & 33,44460858 \\
\hline Espírito Santo & $\begin{array}{r}9.473 .46 \\
6 \\
\end{array}$ & 1.211 .275 & $\begin{array}{r}12,7859750 \\
6 \\
\end{array}$ & 1.632 .708 & $\begin{array}{r}17,2345369 \\
7 \\
\end{array}$ & 30,02051203 \\
\hline $\begin{array}{l}\text { Rio de } \\
\text { Janeiro }\end{array}$ & $\begin{array}{r}33.033 .9 \\
94 \\
\end{array}$ & 5.229 .192 & $\begin{array}{r}15,8297298 \\
2 \\
\end{array}$ & 3.359 .912 & $\begin{array}{r}10,1710740 \\
8 \\
\end{array}$ & 26,0008039 \\
\hline São Paulo & $\begin{array}{r}125.990 . \\
235\end{array}$ & 11.189 .744 & $\begin{array}{r}8,88143751 \\
8\end{array}$ & 14.428 .280 & 11,4519034 & 20,33334091 \\
\hline SUL & $\begin{array}{r}68.138 .7 \\
84 \\
\end{array}$ & 8.871 .075 & $\begin{array}{r}13,0191272 \\
6 \\
\end{array}$ & 12.950 .493 & $\begin{array}{r}19,0060524 \\
1\end{array}$ & 32,02517967 \\
\hline Paraná & $\begin{array}{r}24.941 .8 \\
42\end{array}$ & 4.249 .016 & $\begin{array}{r}17,0356944 \\
8\end{array}$ & 4.913 .184 & $\begin{array}{r}19,6985611 \\
6\end{array}$ & 36,73425563 \\
\hline $\begin{array}{l}\text { Santa } \\
\text { Catarina }\end{array}$ & $\begin{array}{r}16.071 .0 \\
48\end{array}$ & 1.605 .757 & 9,99161349 & 3.423 .629 & 21,3030849 & 31,29469839 \\
\hline $\begin{array}{l}\text { Rio Grande } \\
\text { do Sul }\end{array}$ & $\begin{array}{r}27.125 .8 \\
93 \\
\end{array}$ & 3.016 .301 & $\begin{array}{r}11,1196376 \\
1 \\
\end{array}$ & 4.613 .680 & $\begin{array}{r}17,0083985 \\
8 \\
\end{array}$ & 28,12803619 \\
\hline $\begin{array}{l}\text { CENTRO- } \\
\text { OESTE }\end{array}$ & $\begin{array}{r}33.989 .2 \\
87\end{array}$ & 4.009 .278 & $\begin{array}{r}11,7957108 \\
1\end{array}$ & 8.320 .820 & $\begin{array}{r}24,4807135 \\
8\end{array}$ & 36,27642439 \\
\hline Mato Grosso & $\begin{array}{r}9.078 .00 \\
2\end{array}$ & 1.029 .245 & $\begin{array}{r}11,3377921 \\
7\end{array}$ & 1.746 .541 & $\begin{array}{r}19,2392665 \\
3\end{array}$ & 30,5770587 \\
\hline $\begin{array}{l}\text { Mato Grosso } \\
\text { do Sul }\end{array}$ & $\begin{array}{r}4.367 .54 \\
5 \\
\end{array}$ & 286.822 & $\begin{array}{r}6,56712180 \\
4 \\
\end{array}$ & 1.590 .977 & $\begin{array}{r}36,4272606 \\
2 \\
\end{array}$ & 42,99438243 \\
\hline Goiás & $\begin{array}{r}13.745 .2 \\
17 \\
\end{array}$ & 2.025 .818 & $\begin{array}{r}14,7383486 \\
2 \\
\end{array}$ & 3.560 .905 & 25,9065026 & 40,64485122 \\
\hline $\begin{array}{l}\text { Distrito } \\
\text { Federal }\end{array}$ & $\begin{array}{r}6.798 .52 \\
3\end{array}$ & 667.393 & $\begin{array}{r}9,81673519 \\
4\end{array}$ & 1.422 .396 & $\begin{array}{r}20,9221326 \\
5\end{array}$ & 30,73886784 \\
\hline BRASIL & $\begin{array}{r}398.100 . \\
428\end{array}$ & 44.470 .083 & 11,170569 & 67.318 .740 & $\begin{array}{r}16,9099893 \\
6\end{array}$ & 28,08055836 \\
\hline
\end{tabular}

Fonte: dados do Boletim do ICMS (BRASIL, 2016b). Dados de 2015.

Da tabela, conclui-se pela elevada participação da tributação da energia no bolo tributário dos Estados, visto que a média nacional é de 28,08\%. A dependência dos Estados da arrecadação do ICMS sobre a energia mostra a dificuldade de uma política energética unificada no Brasil.

Quanto à sistemática de incidência do ICMS sobre a energia, há de ser separada a tributação sobre a energia elétrica (ICMS-Energia Elétrica) e sobre petróleo e combustíveis (ICMS-Combustíveis). As bases normativas mais relevantes para a análise desse imposto são 
a própria Constituição Federal e a Lei Complementar nº 87, de 1996, chamada Lei Kandir, que dispõe sobre normas gerais de ICMS.

A Constituição, para fins de incidência do ICMS, considerou o consumo de energia elétrica como análogo do consumo de bens em geral. Segundo Carraza (2007, p. 243), embora todas as operações afetas ao trânsito da energia elétrica (produção pelas usinas e hidrelétricas, distribuição por concessionárias de serviço público e consumo pelos usuários) em tese possam ser objeto de incidência do imposto, apenas o consumo pelo usuário efetivamente caracteriza uma operação de fornecimento de energia, de modo que apenas essa operação é tributável pelo ICMS-Energia Elétrica.

Essa colocação de Carraza encontra eco na legislação. O art. $9^{\circ}, \S 1^{\circ}$, inciso II, da Lei Kandir, dispõe que as empresas geradoras ou distribuidoras de energia elétrica, nas operações internas e interestaduais, são responsáveis na condição de contribuinte ou de substituto tributário, pelo pagamento do imposto, desde a produção ou importação até a última operação, sendo seu cálculo efetuado sobre o preço praticado na operação final, assegurado seu recolhimento ao Estado onde deva ocorrer essa operação ${ }^{35}$.

Também é possível a tributação pelo ICMS de operações de importação de energia elétrica, por força do art. 155, § $2^{\circ}$, inciso IX, alínea "a", da Constituição, com a redação dada pela Emenda Constitucional n ${ }^{0} 33 / 2001^{36}$. Já a exportação de energia elétrica é imune à incidência do ICMS, nos termos do art. 155, $\S 2^{\circ}$, inciso X, alínea "a", da Carta.

Considerando que o ICMS é um tributo estadual, coube também à Constituição regulamentar a estrutura da tributação de operações interestaduais como forma de gerar equilíbrio financeiro entre as entidades da federação. No caso da tributação da energia elétrica, tal é ainda mais relevante, pois os potenciais de energia hidráulica, por exemplo, se concentram em determinados locais do território nacional, o que poderia beneficiar em demasia os Estados produtores/exportadores de energia elétrica.

Por essa razão, o art. $155, \S 2^{\circ}$, inciso $X$, alínea "b”, da redação original da Constituição, vedou a incidência do ICMS sobre operações que destinem a outros Estados petróleo, inclusive lubrificantes, combustíveis líquidos e gasosos dele derivados, e energia

\footnotetext{
${ }^{35}$ Também o art. 34, § $9^{\circ}$, do Ato das Disposições Constitucionais Transitórias tem previsão semelhante: “Até que lei complementar disponha sobre a matéria, as empresas distribuidoras de energia elétrica, na condição de contribuintes ou de substitutos tributários, serão as responsáveis, por ocasião da saída do produto de seus estabelecimentos, ainda que destinado a outra unidade da Federação, pelo pagamento do imposto sobre operações relativas à circulação de mercadorias incidente sobre energia elétrica, desde a produção ou importação até a última operação, calculado o imposto sobre o preço então praticado na operação final e assegurado seu recolhimento ao Estado ou ao Distrito Federal, conforme o local onde deva ocorrer essa operação."

${ }^{36}$ A prática tributária se refere a essa hipótese como ICMS-Importação. Trata-se de caso curioso de um imposto aduaneiro de competência estadual.
} 
elétrica. É a hipótese de imunidade da exportação interestadual de produtos de energia. Essa imunidade é compensada com o pagamento de participação (royalties) devida ao Estado produtor de petróleo e energia elétrica, nos termos do art. $20, \S 1^{\circ}$, da Constituição ${ }^{37}$.

A distribuição de recursos entre os entes da federação, portanto, desenha o seguinte quadro: o Estado produtor de energia elétrica derivada de potencial hidráulico recebe royalties decorrentes da produção enquanto o Estado consumidor dessa energia é remunerado com o ICMS incidente sobre a energia elétrica. A mesma estrutura é aplicável ao comércio de combustíveis derivados de petróleo.

Há críticas na literatura a esse esquema. Diz-se que a atribuição de royalties aos Estados produtores decorre de uma visão que naturaliza os recebimentos de receitas pelos territórios impactados pelo seguimento de exploração e produção de petróleo (SERRA, 2007, p. 79$)^{38}$. Fala-se em "naturalizar" no sentido de que a atribuição de royalties ao estado produtor fosse um imperativo de equidade.

A crítica envolve a ideia de que essa "naturalização" nada tem de neutra. $\mathrm{Na}$ realidade, promove a concentração territorial de renda nos Estados produtores em detrimento de outros critérios como, por exemplo, a equidade intergeracional (SERRA, 2007, p. 81). Não bastasse isso, esse critério ignora que a instalação da indústria de exploração e produção de petróleo e gás importa no aumento da base econômica da tributação de outras rendas estaduais e municipais, como IPTU, ISS, ICMS, etc. Assim, é causado um sobrefaturamento de governos subnacionais, ampliando as desigualdades regionais no Brasil. Outro efeito deletério que pode ser apontado é que é gerada uma elevada dependência da renda de royalties nos Estados produtores. A queda no valor do barril de petróleo, nesses casos, pode gerar crises financeiras como a vivida pelo Estado do Rio de Janeiro entre 2015 e 2017.

Há que se salientar, contudo, uma diferença entre os royalties devidos na exploração de petróleo e os devidos em razão da exploração de potenciais de energia hidráulica. No caso desses últimos, há muitas vezes alagamento de áreas extensas, reduzindo

\footnotetext{
37 “Art. 20 [...]§ $1^{\circ}$ É assegurada, nos termos da lei, aos Estados, ao Distrito Federal e aos Municípios, bem como a órgãos da administração direta da União, participação no resultado da exploração de petróleo ou gás natural, de recursos hídricos para fins de geração de energia elétrica e de outros recursos minerais no respectivo território, plataforma continental, mar territorial ou zona econômica exclusiva, ou compensação financeira por essa exploração."

38 “O que não é possível, nem justificável, é que estados (petrolíferos) que servem de suporte, de apoio, que têm suas estruturas modificadas pela presença de uma nova tecnologia que lá aporta e, por isso mesmo, modifica os níveis de vida, obrigando que as infraestruturas estaduais sejam reforçadas, com ônus altos para seus parcos cofres, nada recebam a não ser o orgulho de dizer: 'temos petróleo'. Não é lícito, portanto, que esses estados, sem nada, ainda arquem com os ônus de suportar essas despesas, sem nenhuma retribuição àquilo que a natureza colocou no confronto de seus territórios." (discurso do Senador José Sarney, em CONGRESSO NACIONAL, 1971, p. 59).
} 
e até mesmo impossibilidade seu aproveitamento econômico pela comunidade local. Os royalties, nesses casos, têm caráter quase que indenizatório da capacidade econômica perdida em razão de empreendimentos hidrelétricos.

As alíquotas do ICMS-Energia Elétrica são definidas por lei estadual, havendo a possibilidade de o Senado Federal fixar alíquotas mínimas para operações internas e, para resolver conflito específico que envolva o interesse dos Estados, fixar também alíquotas máximas.

As alíquotas tendem a variar bastante entre os Estados, conforme se consigna na tabela abaixo:

Tabela 2 - Alíquotas de ICMS-Energia Elétrica no Brasil ${ }^{39}$

\begin{tabular}{|c|c|c|c|c|c|}
\hline \multicolumn{2}{|c|}{ Norte } & \multicolumn{2}{|l|}{ Nordeste } & \multicolumn{2}{|c|}{ Centro-Oeste } \\
\hline Estado & Alíquota & Estado & Alíquota & Estado & Alíquota \\
\hline Acre & Isento - $25 \%$ & Maranhão & $19 \%$ & Mato Grosso & $27 \%$ \\
\hline Amazonas & $25 \%$ & Piauí & $20 \%-25 \%$ & Mato Grosso do Sul & $17 \%$ \\
\hline Pará & $25 \%$ & Ceará & $27 \%$ & Goiás & $29 \%$ \\
\hline Rondônia & $17 \%$ & Rio Grande do Norte & $18 \%-27 \%$ & Distrito Federal & $12 \%-21 \%$ \\
\hline Amapá & $12 \%$ & Paraíba & $17 \%-25 \%$ & \multicolumn{2}{|l|}{ Sul } \\
\hline Roraima & $17 \%$ & Pernambuco & $25 \%$ & Estado & Alíquota \\
\hline Tocantins & $25 \%$ & Alagoas & $17 \%-25 \%$ & Paraná & $29 \%$ \\
\hline \multicolumn{2}{|c|}{ Sudeste } & Sergipe & $25 \%-27 \%$ & Santa Catarina & $25 \%$ \\
\hline Estado & Alíquota & Bahia & $27 \%$ & Rio Grande do Sul & $30 \%$ \\
\hline Minas Gerais & $18 \%$ & & & & \\
\hline Espírito Santo & $7 \%-25 \%$ & & & & \\
\hline Rio de Janeiro & $19 \%-29 \%$ & & & & \\
\hline São Paulo & $18 \%$ & & & & \\
\hline
\end{tabular}

Fonte: dados da ABRADEE (2016). Consideradas as alíquotas vigentes em 2015, para consumo residencial.

Quanto à base de cálculo, já se destacou tratar do preço praticado na operação final, ou seja, a tarifa paga pelo consumidor final. A despeito da sistemática de não cumulatividade própria do ICMS, a legislação complementar restringe o aproveitamento de créditos decorrentes do consumo de energia elétrica às seguintes hipóteses: quando for objeto de operação de saída de energia elétrica; quando consumida no processo de industrialização; quando seu consumo resultar em operação de saída ou prestação para o exterior, na proporção destas sobre as saídas ou prestações totais; a partir de $1^{\circ}$ de janeiro de 2020 nos demais casos (art. 33, inciso II, da Lei Kandir) ${ }^{40}$. Na prática, portanto, o ICMSEnergia Elétrica muitas vezes se comporta como um tributo monofásico, pois é recolhido

\footnotetext{
${ }^{39}$ Dados da ABRADEE (2016). Consideradas as alíquotas vigentes em 2015, para consumo residencial.

${ }^{40} \mathrm{O}$ Superior Tribunal de Justiça já teve oportunidade de entender legítimas essas restrições legais: AgRg no AREsp 126.078/RS, Rel. Ministro BENEDITO GONÇALVES, PRIMEIRA TURMA, julgado em 20/11/2012, DJe $26 / 11 / 2012$.
} 
apenas uma vez - no momento do consumo - e na maioria das situações sequer gera créditos posteriores.

Também pode ser considerada tributação estadual da energia o ICMS incidente sobre produção, importação, circulação, distribuição ou consumo de lubrificantes e combustíveis líquidos e gasosos (ICMS-Combustíveis).

A Constituição, nesse sentido, também incluiu o consumo desses materiais como tributação sobre o consumo em geral para fins de incidência do ICMS. Por outro lado, os serviços de produção, importação, circulação e distribuição não são tributáveis pelos Municípios, por intermédio do Imposto sobre Serviços de Qualquer Natureza - ISS, mercê da aplicação do já citado art. $155, \S 3^{\circ}$, da Constituição.

Acerca da competência para a tributação das operações com combustíveis e derivados, prevê o art. 155, $\S 2^{\circ}, \mathrm{X}$, “b”, da Constituição que não incidirá ICMS nas operações que destinem a outros Estados petróleo, inclusive lubrificantes, combustíveis líquidos e gasosos dele derivados. Ou seja, exclusivamente para petróleo e seus derivados, no que diz respeito ao comércio interestadual, a Constituição adota o critério de destino. Por raciocínio contrário, é permitida a tributação no Estado de origem no caso de combustíveis e lubrificantes não derivados de petróleo.

Essa disposição se dá em razão da necessidade de equilíbrio financeiro da Federação, pois os Estados produtores de petróleo são beneficiários de royalties (art. 20, $\S 1^{\circ}$, da Constituição), enquanto os Estados consumidores são beneficiários da arrecadação de ICMS.

É preciso, contudo, destacar a profunda alteração na sistemática de tributação de combustíveis trazida pela Emenda Constitucional $n^{0} 33 / 2001$. A Emenda, incluindo a alínea " $h$ " ao inciso XII do $\S 2^{\circ}$ do art. 155, dispôs lei complementar pode definir os lubrificantes e combustíveis sobre os quais o ICMS incidirá uma única vez (ICMS monofásico), hipótese em que não se aplicará a imunidade do comércio interestadual acima comentada.

Embora a redação do art. $155, \S 2^{\circ}$, XII, exija lei complementar para definir quais os bens que submeterão ao regime monofásico, o art. $4^{\circ}$ da Emenda Constitucional n ${ }^{\circ} 33 / 2001$ dispôs que enquanto não entrar em vigor a referida lei complementar, os Estados e o Distrito Federal, mediante convênio celebrado nos termos do $\S 2^{\circ}$, XII, "g", do mesmo artigo, fixarão normas para regular provisoriamente a matéria. Em outros termos, os convênios do CONFAZ passaram a definir o regime de ICMS monofásico.

Atualmente, a regulamentação do ICMS monofásico é tratada pelo ConvênioICMS n $^{\circ} 110$, de 28 de setembro de 2007. Esse convênio abrange a maioria dos combustíveis, 
como gasolina em geral, álcool anidro, querosenes, óleos combustíveis, gás de petróleo, dentre outros. Contudo, não há nesse Convênio a fixação de uma alíquota uniforme.

A Emenda também regulamentou diversos aspectos da incidência do ICMS monofásico (art. 155, § $4^{\circ}$ ). Nas operações com os lubrificantes e combustíveis derivados de petróleo, o imposto caberá ao Estado onde ocorrer o consumo (inciso I, critério de destino); nas operações interestaduais, entre contribuintes, com gás natural e seus derivados, e lubrificantes e combustíveis não derivados do petróleo, o imposto será repartido entre os Estados de origem e de destino, mantendo-se a mesma proporcionalidade que ocorre nas operações com as demais mercadorias (inciso II, critério misto entre destino e origem); nas operações interestaduais com gás natural e seus derivados, e lubrificantes e combustíveis não derivados do petróleo, destinadas a não contribuinte, o imposto caberá ao Estado de origem (inciso III, critério de origem).

A Emenda 33, então, adotou várias matizes entre os critérios de origem e destino, a depender da natureza do contribuinte. Observe-se, contudo, que a Emenda Constitucional $n^{\circ}$ 87/2015 modificou o regime de repartição do ICMS sobre mercadorias no comércio interestadual, a qual se aplica na hipótese do inciso II. No regime geral, aplicável por extensão aos combustíveis e lubrificantes não derivados do petróleo entre contribuintes em Estados diferentes, adotar-se-á a alíquota interestadual e caberá ao Estado de localização do destinatário o imposto correspondente à diferença entre a alíquota interna do Estado destinatário e a alíquota interestadual.

A base de cálculo do tributo é o valor da operação. A alíquota, por sua vez, pode ser definida por lei estadual no caso de operações internas. Contudo, no caso dos combustíveis submetidos ao regime monofásico, a estipulação das alíquotas do ICMSCombustíveis será feita mediante convênio do CONFAZ, uniformes em todo território nacional, podendo ser diferenciadas por produto (art. 155, $\S 4^{\circ}$, IV, da Constituição).

As alíquotas estaduais de ICMS-Combustíveis também mostram disparidade, como ocorre no caso da energia. Veja-se a situação na seguinte tabela:

Tabela 3 - Alíquotas de ICMS-Combustíveis no Brasil

\begin{tabular}{|l|r|l|r|l|r|}
\hline \multicolumn{2}{|c|}{ Norte } & \multicolumn{2}{c|}{ Nordeste } & \multicolumn{2}{c|}{ Centro-Oeste } \\
\hline Estado & Alíquota & Estado & Alíquota & Estado & Alíquota \\
\hline Acre & $*$ & Maranhão & $*$ & Mato Grosso & $*$ \\
\hline Amazonas & $25 \%$ & Piauí & $27 \%$ & Mato Grosso do Sul & $25 \%$ \\
\hline Pará & $29 \%$ & Ceará & $29 \%$ & Goiás & $30 \%$ \\
\hline Rondônia & $26 \%$ & Rio Grande do Norte & $29 \%$ & Distrito Federal & $28 \%$ \\
\hline Amapá & $25 \%$ & Paraíba & $27 \%$ & \multicolumn{2}{c|}{ Sul } \\
\hline
\end{tabular}




\begin{tabular}{|c|c|c|c|c|c|}
\hline Roraima & $25 \%$ & Pernambuco & $29 \%$ & Estado & Alíquota \\
\hline Tocantins & $29 \%$ & Alagoas & $29 \%$ & Paraná & $29 \%$ \\
\hline \multicolumn{2}{|c|}{ Sudeste } & Sergipe & $27 \%$ & Santa Catarina & $25 \%$ \\
\hline Estado & Alíquota & Bahia & $*$ & Rio Grande do Sul & $30 \%$ \\
\hline Minas Gerais & $29 \%$ & & & & \\
\hline Espírito Santo & $*$ & & & & \\
\hline Rio de Janeiro & $30 \%$ & & & & \\
\hline São Paulo & $25 \%$ & & & & \\
\hline
\end{tabular}

Fonte: dados do CONFAZ (BRASIL, 2016c). Consideradas alíquotas incidentes especificamente sobre gasolina. Grande parte dos Estados aplica alíquotas diversas por produto, em especial o álcool com fins carburantes, o diesel e o querosene de aviação.

*Alíquotas não disponibilizadas pelos Estados ao CONFAZ.

Logo se nota que a tributação do ICMS-Combustíveis, ao menos sobre a gasolina, varia menos ( 5 pontos percentuais) do que o ICMS-Energia Elétrica (12 pontos percentuais). É preciso atentar à circunstância de que outros combustíveis podem variar também, no caso dos Estados que adotam alíquotas por produto.

Discutida a tributação estadual da energia, cabe analisar a tributação em âmbito federal.

Os tributos incidentes sobre o comércio internacional - Imposto de Importação e Imposto de Exportação - podem incidir sobre produtos de energia, conforme já salientado. As alíquotas desses impostos, por permissivo do art. 153, $\S 1^{\circ}$, da Constituição Federal, podem ser definidas por ato do Poder Executivo. Em concreto, as alíquotas dos impostos são definidas pela Câmara de Comércio Exterior - CAMEX, respeitada a Tarifa Externa Comum definida pelo Mercosul, salvo eventuais reservas.

Atualmente, a Resolução-CAMEX n ${ }^{\circ}$ 94/2011 dispõe sobre as alíquotas de II e IE. A aludida Resolução estabelece regime de alíquota zero, na conformidade da TEC do Mercosul, para gasolina e a maioria dos combustíveis minerais. O álcool, por sua vez, é objeto de tributação à alíquota de $20 \%$.

No âmbito federal, há ainda a tributação pelas contribuições sociais ao PIS/Pasep e Cofins, incidentes sobre a receita da venda de energia. Muito embora a incidência dessas contribuições se dê sobre a receita, ou seja, a renda, a metodologia via de regra plurifásica e não cumulativa (decorrente das Leis $\mathrm{n}^{0} 10.637 / 2002$ e 10.833/2002) que ocorre sobre as receitas associa normalmente essas contribuições à tributação do consumo. Do ponto de vista prático, basta notar o destaque nas contas de energia elétrica e nas notas fiscais de combustíveis o destaque dos tributos em questão. 
Essas contribuições, ao incidirem de forma plurifásica e não cumulativa sobre bens especiais (energia elétrica e combustíveis) têm "comportamento" semelhante ao imposto sobre valor agregado (IVA), criado para incidência sobre o consumo, não a renda. Daí tratalos desta forma no presente trabalho.

Daí inserirmos essas contribuições na descrição da tributação da energia.

As contribuições PIS/Pasep e Cofins têm base constitucional no art. 195, inciso I, "b", da Constituição Federal, que elenca como base de financiamento da seguridade social a contribuição da empresa sobre a receita ou o faturamento. Têm natureza de contribuições sociais para a seguridade social. No âmbito infraconstitucional, são regidas pela Leis Complementares $n^{\circ}$ 26/75 (PIS/Pasep) e 70/1991 (Cofins), bem como pelas citadas Leis $n^{\circ}$ 10.637/2002 (PIS/Pasep) e 10.833/2002 (Cofins), que tratam da tributação pelo regime não cumulativo.

O Supremo Tribunal Federal já teve a oportunidade de analisar a questão da possibilidade de tributação por essas contribuições sociais do faturamento decorrente da venda de combustíveis à luz do art. 155, $\S 3^{\circ}$, da Constituição Federal, que restringe a tributação de combustíveis e energia elétrica ao ICMS e os impostos de importação e exportação $^{41}$. Em síntese, a Suprema Corte entendeu que o art. $155, \S 3^{\circ}$, impede a incidência de outros impostos que não elenca, mas não restringe a incidência de outras espécies tributárias, como as contribuições sociais. Assim, entendeu legítima a incidência das contribuições ao PIS/Pasep e Cofins sobre a receita da venda de combustíveis, em decisão cujas razões são extensíveis à tributação da receita sobre a distribuição de energia elétrica.

Sobre a energia elétrica, as contribuições ao PIS/Pasep e Cofins incidem sobre a sistemática plurifásica não cumulativa, às alíquotas de $1,65 \%$ e $7,6 \%$, respectivamente. $\mathrm{O}$ consumo de energia elétrica gera creditamento, via de regra, ao estabelecimento empresarial.

Já no caso de combustíveis, a tributação se dá em regime monofásico, nos termos da Lei $n^{\circ} 9.718 / 1998$ (art. $4^{\circ}$ e $5^{\circ}$ ). Os produtores e importadores de combustíveis derivados de petróleo são tributados às seguintes alíquotas: 5,08\% (PIS/Pasep) e 23,44\% (Cofins), no caso de gasolina e correntes, exceto gasolina de aviação; 4,21\% (PIS/Pasep) e 19,42\% (Cofins), no caso de óleo diesel e correntes; 10,2\% (PIS/Pasep) e 47,4\% (Cofins), no caso de gás liquefeito de petróleo (GLP) e gás natural.

As receitas da venda álcool para fins carburantes são tributadas às seguintes alíquotas: $1,5 \%$ (PIS/Pasep) e 6,9\% (Cofins), no caso de produtores e importadores; $3,75 \%$

\footnotetext{
${ }^{41}$ RE 230337, Relator(a): Min. CARLOS VELLOSO, Tribunal Pleno, julgado em 01/07/1999.
} 
(PIS/Pasep) e 17,25\% (Cofins), no caso de distribuidores. Ainda no caso do álcool para fins carburantes, há previsão de alíquota zero na venda por distribuidor, no caso de venda de álcool anidro adicionado à gasolina; por comerciante varejista, em qualquer caso; e nas operações realizadas em bolsa de mercadorias e futuros.

Há ainda, no caso do álcool de fins carburantes, um regime especial de tributação por valor específico também previsto na Lei $\mathrm{n}^{\circ}$ 9.718/1998. Para produtores e importadores, cobra-se R\$ 23,38 (PIS/Pasep) e R\$ 107,52 (Cofins); Para distribuidores, R\$ 58,45 (PIS/Pasep) e R\$268,80 (Cofins).

Por fim, a Cide-Combustíveis é regulada diretamente pela Constituição Federal no art. $177, \S 4^{\circ}$, com redação da Emenda Constitucional no 33/2001, bem como pela Lei no 10.336/2001. São contribuintes da Cide o produtor, o formulador e o importador, pessoa física ou jurídica, de gasolinas e suas correntes; diesel e suas correntes; querosene de aviação e outros querosenes; óleos combustíveis (fuel-oil); gás liquefeito de petróleo, inclusive o derivado de gás natural e de nafta; e álcool etílico combustível.

$\mathrm{Na}$ permissibilidade do art. $177, \S 4^{\circ}$, o critério quantitativo do tributo usa alíquotas específicas e reajustáveis por ato do Poder Executivo: gasolina, R $\$ 860,00$ por m³ diesel, R\$ 390,00 por $\mathrm{m}^{3}$; querosene de aviação, $\mathrm{R} \$ 92,10$ por $\mathrm{m}^{3}$; outros querosenes, $\mathrm{R} \$$ 92,10 por $\mathrm{m}^{3}$; óleos combustíveis com alto teor de enxofre, $\mathrm{R} \$ 40,90$ por t; óleos combustíveis com baixo teor de enxofre, $\mathrm{R} \$ 40,90$ por t; gás liquefeito de petróleo, inclusive o derivado de gás natural e da nafta, $\mathrm{R} \$ 250,00$ por t; álcool etílico combustível, $\mathrm{R} \$ 37,20$ por $\mathrm{m}^{3}$.

A receita da contribuição deverá ser utilizada para o pagamento de subsídios a preços ou transporte de álcool combustível, gás natural e seus derivados e derivados de petróleo; financiamento de projetos ambientais relacionados com a indústria do petróleo e do gás; financiamento de programas de infraestrutura de transportes.

A Cide-Combustíveis é o instrumento tributário da União por excelência para regulação do mercado de combustíveis. Isso tanto no plano da despesa pública, mediante subsídios aos preços do transporte de álcool combustível, gás natural e seus derivados e derivados de petróleo quanto no plano da receita, mediante redução de alíquotas para controle de preços.

Como pôde se notar desta exposição, a tributação de combustíveis no Brasil se mostra bastante complexa e onerosa. Convivem sobre a tributação da energia uma série de tributos de natureza plurifásica e não cumulativa, ou seja, em última instância, IVA's. Parte deles estaduais - ICMS-Energia Elétrica e ICMS-Combustíveis - e parte deles federais - 
PIS/Pasep e Cofins. A convivência de IVA's estaduais e federais gera elevada complexidade ao sistema.

A inclusão dos IVA's federais - PIS/Pasep e Cofins - decorreu de uma necessidade de receita da União, a qual buscou recursos mediante tributação por contribuições, as quais não se submetem a repartição com Estados e Municípios. Uma necessidade fiscal, repita-se, que implicou em elevado aumento de complexidade da tributação do consumo da energia. Além disso, a convivência com tributos estaduais também de finalidade fiscal reduziu bastante o poder de indução econômica sobre a energia via a política tributária.

A onerosidade, por sua vez, acaba recaindo sobre o consumidor da energia. Muito embora a incidência se dê na cadeia produtiva, evidentemente os agentes econômicos repassam o ônus tributário ao consumidor, o que aumenta o preço da energia no País, bem como de outros bens que dela dependem para sua produção.

As consequências desse quadro serão analisadas em capítulo posterior deste trabalho.

\subsection{ARGENTINA}

O sistema tributário argentino é delimitado pela Constituição daquele país em competências do Estado Nacional, das Províncias e dos Municípios (SALDANHA, 2008, p. 152-153). A competência desses entes é definida com base na classificação dos tributos quanto à base de incidência (renda, patrimônio e consumo) e quanto à definição do contribuinte (tributos diretos e indiretos).

Dessa forma, ao governo central cabem os tributos sobre a renda, bens pessoais, transferências de imóveis entre pessoas físicas, valor agregado, combustíveis líquidos e gás natural, seguridade social e direitos aduaneiros em geral. Aos governos provinciais, cabem os tributos sobre ingressos brutos, manifestações parciais de patrimônio (imóveis e veículos automotores), bem como selos e taxas por prestação de serviços. Aos municípios compete a cobrança de selos e taxas sobre serviços prestados e direitos específicos.

Por outro lado, os impostos diretos são de competência nacional. Os tributos indiretos de caráter aduaneiro também são de competência nacional, mas os de caráter meramente interno são de competência provincial. 
No que diz respeito à tributação da energia, cabe destacar as incidências do IVA e do Imposto Específico sobre Combustíveis Líquidos e Gás Natural, ambos de competência do Estado Nacional.

O IVA argentino é um tributo geral sobre o consumo de competência do governo nacional (ARGENTINA, 1997). Trata-se ainda de um tributo de incidência plurifásica não cumulativa $^{42}$. Incide sobre as vendas de coisas móveis, físicas ou ideais, e ainda sobre obras, prestações de serviços e fornecimento em geral de bens. Há previsão expressa para a incidência sobre fornecimento de energia elétrica e gás (Art. 5\%, “a”, I, do Decreto $n^{\circ}$ 280/1997).

A alíquota geral do IVA é de $21 \%$, mas existem casos de redução de alíquota até 10,5\% e incrementos até 27\% (FIEL, 2015, p. 22). Os combustíveis líquidos, gás e energia elétrica são tributados em regra pela alíquota geral de $21 \%$. Entretanto, o fornecimento de energia elétrica e de gás para finalidades não residenciais é tributado pela alíquota de $27 \%$ (artigo 28 do Decreto $\left.\mathrm{n}^{\mathrm{0}} 280 / 1997\right)^{43}$.

Além do IVA, na Argentina existe ainda a tributação de combustíveis líquidos e gás natural por um imposto especial sobre o consumo, de competência nacional. Há três justificativas para a instituição desse imposto especial (FIEL, 2015, p. 38). A primeira é a necessidade de imposição de custos tributários a produtos que geram externalidades negativas. No caso dos combustíveis líquidos, por exemplo, há o custo ambiental de seu consumo. A segunda justificativa é a necessidade de possibilitar uma política regulatória por medidas extrafiscais que não seria tão eficiente se desenvolvida pelo IVA. No caso dos combustíveis, o imposto específico pode variar em função do aumento do preço do produto como mecanismo regulatório. A terceira justificativa é que determinados produtos têm demanda pouco elástica, ou seja, o consumo desses bens varia pouco em função de um aumento de seu preço. Assim, o tributo especial tem uma arrecadação potencialmente maior, dada a menor elasticidade da demanda.

\footnotetext{
42 "El impuesto al valor agregado (IVA) grava a todas las ventas, sean estas mayoristas o minoristas, permitiendo deducir los costos intermedios. Puede decirse entonces que, dado que el valor final es igual a la suma del valor agregado en cada etapa, la base imponible es el monto de las ventas finales.” (FIEL, 2015, p. 20).

43 "Esta alícuota se incrementará al veintisiete por ciento (27\%) para las ventas de gas, energía eléctrica y aguas reguladas por medidor y demás prestaciones comprendidas en los puntos 4, 5 y 6, del inciso e) del artículo 3o, cuando la venta o prestación se efectúe fuera de domicilios destinados exclusivamente a vivienda o casa de recreo o veraneo o en su caso, terrenos baldíos y el comprador o usuario sea un sujeto categorizado en este impuesto como responsable inscripto o se trate de sujetos que optaron por el Régimen Simplificado para pequeños contribuyentes." (ARGENTINA, 1997).
} 
O imposto especial sobre combustíveis líquidos e gás é regulamentado pela Lei $\mathrm{n}^{\mathrm{o}}$ 23.966, de $1^{\circ}$ de agosto de 1991 (ARGENTINA, 1991). As alíquotas variam em função do produto. Os combustíveis líquidos são tributados por alíquotas que variam de 19\% (para querosene) até 70\% (nafta). Há a previsão de valores mínimos por litro, mas, na prática, o imposto é cobrado ad valorem (FIEL, 2015, p. 39).

O gás natural comprimido é sujeito à alíquota de $16 \%$ sobre o preço de venda ao consumidor. O gas oil e o gás liquefeito de petróleo (GLP) para fins automotores é tributado a $22 \%$ sobre o preço de venda. Existe também um adicional de imposto de $5 \%$ para naftas e $9 \%$ para gás natural com fins automotores, incidente sobre o preço de venda. Esse adicional é destinado ao Fundo Hídrico de Infraestrutura. Por fim, há ainda um encargo sobre gás natural e gás liquefeito de petróleo, pago pelas distribuidoras quando da entrada do produto na rede de distribuição. A alíquota aplicável é de 7,5\% sobre o preço de venda.

Por fim, importa salientar que na Argentina era isenta da incidência do imposto específico a importação de combustíveis como gasolina e nafta (FIEL, 2015, p. 40). Entretanto, essa isenção foi suspensa em 2015 (ARGENTINA, 2015).

Pode-se observar que na Argentina a energia elétrica é tributada apenas por um imposto geral sobre o consumo, enquanto os combustíveis líquidos e o gás são tributados por um imposto geral (o IVA) e um específico (o Imposto Específico sobre Combustíveis Líquidos e Gás Natural). Cabe observar também que todos os impostos que incidem sobre a energia são de competência nacional.

\subsection{PARAGUAI}

Ao contrário do Brasil, o Paraguai é um Estado unitário. Daí ser inaplicável a discussão sobre a repartição federativa de competências tributárias.

No Paraguai também há a tributação por um imposto de valor agregado (IVA). Esse imposto incide sobre a alienação de bens, a prestação de serviços (excluídos os prestados em caráter pessoal com relação de dependência) e sobre a importação de bens (PARAGUAI, 1991, art. 77). Consideram-se alienações as operações gratuitas ou onerosas de entrega de bens com transferência de propriedade ou que outorguem ao recebedor a faculdade de dispor do bem como se proprietário fosse. As prestações de serviços excluem aqueles prestados em relação trabalhista.

A alíquota básica do IVA é de 10\%, com uma taxa especial de 5\% aplicável aos produtos da cesta básica, produtos farmacêuticos e venda de bens imóveis. O IVA paraguaio 
também é um imposto geral sobre o consumo plurifásico e não cumulativo, cuja base de cálculo é definida como o preço da operação deduzido dos créditos fiscais admitidos pela legislação.

O fornecimento de energia elétrica e gás é tributável pelo IVA. Por outro lado, a venda de combustíveis derivados do petróleo é isenta do pagamento de IVA (PARAGUAI, 1991, art. 83, 1, “e”).

Os combustíveis derivados de petróleo são tributados por um imposto especial (Impuesto Selectivo al Consumo). Esse imposto grava a importação de produtos estrangeiros e a primeira alienação de produtos nacionais (tributo monofásico). No caso de combustíveis derivados do petróleo, a alíquota aplicável é de $50 \%$ e a base de cálculo é o preço da operação tributada, excluído o IVA, se houver.

No caso da relação Brasil-Paraguai, é importante destacar a existência da usina hidrelétrica Itaipu Binacional. O Tratado entre a República Federativa do Brasil e a República do Paraguai para o Aproveitamento Hidrelétrico dos Recursos Hídricos do Rio Paraná, firmado em 26 de abril de 1973, dispõe em seu Artigo XXII que nenhum dos países “aplicará impostos, taxas e empréstimos compulsórios, de qualquer natureza, à ITAIPU e aos serviços de eletricidade por ela prestados". Há, portanto, uma isenção decorrente do tratado ao fornecimento de energia elétrica por Itaipu ${ }^{44}$.

No Paraguai, portanto, a energia elétrica e o gás natural são tributados por um imposto geral sobre o consumo. Já os combustíveis derivados de petróleo são tributados por um imposto especial.

\subsection{URUGUAI}

Assim como o Paraguai, o Uruguai é um Estado unitário, sendo despicienda a discussão sobre a competência de entes subnacionais na tributação da energia. Também de forma semelhante ao modelo paraguaio, a tributação da energia no Uruguai compreende um tributo geral sobre o consumo - o IVA - e um tributo especial sobre o consumo de combustíveis, denominado Impuesto Especifico Interno (IMESI).

No Uruguai, o IVA é a principal fonte de recursos tributários do governo e representa cerca de 50\% da arrecadação nacional (URUGUAI, 2015, p. 5). Inclusive, as

\footnotetext{
${ }^{44}$ Da perspectiva do Brasil, isso não impede a cobrança de ICMS sobre o consumo da energia elétrica produzida em Itaipu. Doutro lado, é entendimento da Consultoria-Geral da União que o faturamento de Itaipu decorrente da geração de energia elétrica é isento da incidência da Cofins e da contribuição ao PIS/Pasep (BRASIL, 1994).
} 
receitas do IVA são em grande parte (30\%) direcionadas ao custeio da Seguridade Social (SALDANHA, 2008, p. 159).

O IVA uruguaio incide sobre a importação de bens, circulação interna de bens e sobre a prestação de serviços dentro do território do país, bem como sobre a adição de valor originada da construção realizada em imóveis (URUGUAI, 2015, p. 24). A circulação de energia elétrica é abrangida na incidência do IVA. Entretanto, existe isenção específica para a circulação de combustíveis derivados de petróleo, exceto o óleo combustível. Além disso, também é isenta da incidência do IVA a importação de petróleo cru (SALDANHA, 2008, p. 162).

A alíquota básica do IVA é de $22 \%$, mas existe uma alíquota especial de $10 \%$ aplicável a produtos alimentícios de primeira necessidade, medicamentos e serviços prestados por hotéis relacionados à hospedagem (URUGUAI, 2015, p. 25).

O IMESI, por outro lado, tributa a primeira venda no mercado interno ou a importação de uma série de bens específicos, sendo a exportação isenta (URUGUAI, 2015, p. 27). É monofásico, portanto. No caso de produtos derivados do petróleo, são aplicadas alíquotas variáveis que podem chegar a um máximo de $133 \%$, no caso da gasolina refinada (URUGUAI, 2015, p. 27).

Havia uma hipótese de incidência para o IMESI relativa à venda de energia elétrica, cuja alíquota aplicável era de 10\%, mas a alíquota é mantida em 0\% desde 1995 (URUGUAI, 1990, art. 31).

No Uruguai, nota-se que a energia elétrica é tributada por um tributo geral sobre o consumo, enquanto os combustíveis derivados de petróleo são tributados por um imposto especial. A exceção neste último caso é o óleo combustível, tributável por ambos os impostos.

\subsection{VENEZUELA}

A Venezuela é um Estado Federativo, composta por um governo federal, governos estaduais e municipais. Para os fins deste trabalho, cabe destacar que a competência tributária sobre o consumo e especificamente sobre energia elétrica, combustíveis e gás é do Estado Nacional. 
$\mathrm{Na}$ Venezuela o consumo também é tributado por um IVA. Este tributo incide sobre vendas de bens móveis corpóreos, importação definitiva de bens móveis, prestação de serviços e na exportação de bens móveis corpóreos ${ }^{45}$ (VENEZUELA, 2014).

A base de cálculo do tributo é preço da operação tributada. As alíquotas são definidas por ato do Poder Executivo, entre o limite mínimo de $8 \%$ e o máximo de $16,5 \%$. As vendas de hidrocarbonetos naturais realizadas por empresas mistas ${ }^{46}$ regidas pela Lei Orgânica de Hidrocarbonetos à Pretróleos de Venezuela S.A. (PDVSA) são sujeitas à alíquota zero.

A lei isenta do pagamento de IVA a venda de combustíveis derivados de hidrocarbonetos, assim como os insumos e aditivos destinados ao melhoramento da qualidade da gasolina; o fornecimento de energia elétrica para uso residencial; o fornecimento de gás para uso residencial, seja canalizado ou por vasilhames; o serviço de transporte de combustíveis derivados de hidrocarbonetos (VENEZUELA, 2014, art. 18 e 19).

A par do IVA, os combustíveis derivados de petróleo são objeto da incidência de tributos especiais monofásicos sobre seu consumo, definidos pela Lei Orgânica de Hidrocarbonetos (VENEZUELA, 2001, art. 48). Essa lei, editada em 2001, regulamenta o regime quase que integralmente público da exploração de hidrocarbonetos no país, dada a relevância do mercado do petróleo na economia venezuelana.

O primeiro tributo é o Impuesto de Consumo Proprio, cuja hipótese de incidência é o consumo de hidrocarbonetos pela própria empresa exploradora. $\mathrm{O}$ tributo incide à alíquota de $10 \%$ por $\mathrm{m}^{3}$ de produto, sendo a base de cálculo o preço final de venda ao consumidor. $\mathrm{Na}$ hipótese do produto não ser oferecido no mercado consumidor, o preço será fixado pelo Ministério de Energia e Petróleo.

O segundo tributo é o Impuesto de Consumo General, incidente no consumo de hidrocarbonetos no mercado interno venezuelano. O contribuinte é o consumidor final, mas o fornecedor é responsável pela retenção do imposto. As alíquotas podem variar entre $30 \% \mathrm{e}$ $50 \%$ por litro do produto, definidas anualmente na lei orçamentária, e incidem sobre o preço final de venda.

A tributação da energia na Venezuela segue, então, o padrão nos demais países latino-americanos: a energia elétrica e o gás natural são tributados por um imposto geral sobre

\footnotetext{
${ }^{45}$ Embora a lei preveja a tributação das exportações, em 2014 a alíquota dessa hipótese de incidência foi zerada (VENEZUELA, 2014, art. $3^{\circ}$ ). A rigor, portanto, as exportações venezuelanas são desoneradas de IVA.

${ }^{46} \mathrm{O}$ art. 22 da Lei Orgânica de Hidrocarbonetos define empresas mistas como aquelas em que o Estado venezuelano detém total controle de decisões por manter mais de 50\% do capital social (VENEZUELA, 2001). A grosso modo, podem ser comparadas às sociedades de economia mista brasileiras.
} 
o consumo, enquanto os derivados de petróleo são tributados por impostos especiais (Impuesto de Consumo Proprio ou Impuesto de Consumo General, a depender da operação).

\subsection{BOLÍVIA}

A estrutura do Estado boliviano é bastante complexa em virtude da Constituição Política do Estado Plurinacional, promulgada em 2009. A Constituição boliviana menciona um Estado Plurinacional e reconhece autonomia ao Nível Central de Estado, aos departamentos, aos municípios e às comunidades indígenas originárias campesinas. Todos esses níveis de governo detêm competências próprias para instituir e cobrar tributos.

A tributação do consumo (e especificamente da energia) está concentrada no Nível Central do Estado, equivalente boliviano da União. São exações sobre o consumo de energia o Imposto sobre Valor Agregado (IVA), o Impuesto Especial a los Hidrocarburos e sus Derivados (IEHD) e o Impuesto Directo a los Hidrocarburos (IDH) (FUNDACIÓN JUBILEO, 2013, p. 12-13).

O IVA boliviano grava as vendas, as prestações de serviços e a importação de bens. A alíquota é única no montante de $13 \%$ incidente sobre o preço da operação. Não há hipóteses de isenção para combustíveis derivados de petróleo como ocorre com outros países pesquisados. Contudo, há isenção ampla para exportações.

O IEHD, por sua vez, tributa a primeira venda ou a importação de derivados de petróleo (tributo monofásico). Ele incide a uma alíquota específica por litro de cada produto que pode ser atualizada anualmente pelo Poder Executivo.

Por fim, o IDH é um tributo inserido pela Lei de Hidrocarbonetos boliviana, de 2005. Depois de sua inserção, o IDH passou a ser a segunda mais relevante fonte de recursos tributários do Estado boliviano, sendo menos relevante apenas que o IVA. A arrecadação do IDH representa 25,96\% das receitas tributárias do Estado (FUNDACIÓN JUBILEO, 2013, p. 21).

O IDH é devido na exploração de petróleo e derivados, assim que extraídos da fonte (monofásico). Daí porque, muito embora a nomenclatura fale de imposto direto, trata-se de um tributo sobre o consumo, ou seja, um imposto indireto.

A alíquota do tributo é de $32 \%$ e a base de cálculo é definida pela lei por cada produto, com base nos royalties (regalias) pagos por cada um deles.

A respeito do gasoduto Brasil-Bolívia, cabe salientar que foram estipuladas isenções especiais pelos dois países pelo Acordo para Isenção de Impostos Relativos à 
Implementação do Projeto do Gasoduto Brasil-Bolívia, celebrado entre o Governo da República Federativa do Brasil e o Governo da República da Bolívia, em Brasília, em 5 de agosto de 1996. O aludido acordo foi promulgado no Brasil pelo Decreto $n^{0} 2.142$, de 5 de fevereiro de 1997.

Pelo acordo, estavam isentas dos impostos vigentes nas diversas esferas de competência das Partes Contratantes, assim como daqueles que fossem criadas no futuro pelas autoridades competentes das referidas Partes, as operações que compreendiam importação de bens e serviços destinados ao uso direto ou a incorporação na construção do gasoduto BrasilBolívia; compra, fornecimento e circulação locais de bens e serviços destinados ao uso direto ou à incorporação na construção do referido gasoduto; financiamento, crédito, câmbio de diversas, seguro e seus correspondentes pagamentos e remessas a terceiros.

Essas isenções somente vigoraram durante a construção do gasoduto e até que alcançasse a capacidade de 30 milhões de $\mathrm{m}^{3} /$ dia.

No caso da Bolívia, portanto, existe a tributação da energia elétrica por um tributo geral e a tributação dos combustíveis tanto pelo tributo geral quanto pro dois tributos especiais sobre o consumo (o IEHD e o IDH).

\subsection{CHILE}

O Estado chileno é unitário. Ao poder político único, portanto, compete tributar o consumo. Tal competência é exercida primeiramente pela instituição do Impuesto a las Ventas e Servicios, o IVA chileno.

O IVA chileno incide sobre vendas de bens e prestação de serviços. Por venda, entende-se toda convenção que implique transferir a título oneroso o domínio de bens corpóreos móveis, bens corpóreos imóveis, excetuados os terrenos, de uma quota de domínio sobre esses bens ou de direitos reais constituídos sobre eles (CHILE, 1976, art. $\left.2^{\circ}, 1\right)$. Por serviço, entende-se a ação ou prestação de uma pessoa a outra pela qual se recebe um interesse, pagamento ou comissão ou qualquer outra forma de recuperação (CHILE, 1976, art. $\left.2^{\circ}, 2\right)$. O tributo comporta poucas isenções e nenhuma delas é afeta a bens ou serviços ligados à energia.

A alíquota do tributo é única, de 19\%.

O Chile ainda comporta um imposto específico e monofásico sobre combustíveis, o Impuesto a los Combustibles regido pela Lei $\mathrm{n}^{0}$ 18.502, de 2013 (CHILE, 2013). Esse imposto grava a importação e a primeira venda de gasolina de fins automotivos e óleo diesel. 
É aplicada uma alíquota específica por $\mathrm{m}^{3}$ de cada produto, medida em Unidades Tributárias Mensais (UTM) ${ }^{47}$. Para a gasolina automotiva, a alíquota é de $6 \mathrm{UTM} / \mathrm{m}^{3}$ e para o óleo diesel é de $1,5 \mathrm{UTM} / \mathrm{m}^{3}$.

Há ainda fatores de correção do valor devido em razão dos chamados componentes variáveis. O fisco chileno estabelece uma pauta fiscal de preços de combustível (precio de paridad) e o compara com o preço praticado pelo contribuinte para venda (precio de referencia). Se o preço de venda é superior ao da pauta fiscal, será devido um imposto complementar por $\mathrm{m}^{3}$ equivalente à diferença de preços, gerando um débito fiscal. Se a pauta fiscal é superior ao preço de venda, é gerado um crédito fiscal no montante da diferença por $\mathrm{m}^{3}$.

A legislação também autoriza ao contribuinte apurar créditos de IVA pelo pagamento do imposto específico incidente sobre óleo diesel que não seja destinado a veículos que transitem por ruas ou vias públicas em geral ${ }^{48}$. É uma hipótese de benefício fiscal que evita a incidência em cascata do imposto específico e do IVA.

O Chile, portanto, tributa o consumo da energia elétrica por um tributo geral e o consumo de combustíveis por um tributo geral e um especial.

\footnotetext{
${ }^{47}$ O valor da UTM em pesos chilenos para janeiro de 2017, para fins de ilustração, é de 46.229. Disponível em: http://www.sii.cl/pagina/valores/utm/utm2017.htm, acessado no dia 28 de dezembro de 2016, às $22 \mathrm{~h}$.

48 Informações do Servicio de Impuestos Internos do Chile. Disponível em: http://www.sii.cl/aprenda_sobre_impuestos/impuestos/impuestos_indirectos.htm\#olp6, acessado em 28 de dezembro de 2016, às $22 \mathrm{~h} 30 \mathrm{~min}$.
} 


\section{CONSTATAÇÕES SOBRE A TRIBUTAÇÃO DA ENERGIA NA AMÉRICA DO SUL E SEUS REFLEXOS NA INTEGRAÇÃO ENERGÉTICA}

Expostos os modelos de tributação da energia na América do Sul cabe, neste ponto, por uma metodologia comparativa, tecer considerações sobre as desequiparações que dificultam a integração energética da região. Para tanto, será utilizado o marco teórico desenvolvido na primeira parte do capítulo 3 deste trabalho.

\subsection{A MÚLTIPLA INCIDÊNCIA DE TRIBUTOS GERAIS SOBRE O CONSUMO NO BRASIL}

Dos casos expostos acima, pode-se notar a existência de dois modelos claros de tributação de modais energéticos. É comum entre todos os modelos (exceto o brasileiro) a tributação da energia por um tributo geral sobre o consumo (o IVA). Contudo, os combustíveis podem ser tributados apenas por um tributo especial (caso do Paraguai, do Uruguai e da Venezuela) ou tanto por um tributo especial quanto por um geral (caso da Argentina, da Bolívia e do Chile). Em todos os casos, contudo, a tributação do consumo de energia cabe ao nível central ou unitário do Estado.

É gritante a divergência do Brasil quando se utiliza de três tributos gerais (ICMS , PIS/Pasep e Cofins) e um tributo especial (CIDE-Combustíveis) para tributar tanto a energia elétrica quanto os combustíveis, além de também submetê-los aos tributos de natureza eminentemente aduaneira. Daí já se observa um descompasso entre a estrutura tributária incidente sobre a energia entre o Brasil e os demais países pesquisados.

A integração energética do continente demandaria, no mínimo, a coordenação ou a harmonização dessas estruturas tributárias. O que há, hoje, é a desoneração de exportações no âmbito do Mercosul e, no caso do Brasil, também com os demais países. Ocorre que essa desoneração não altera a discrepância entre os custos da energia entre esses países. Como já visto, no Brasil a energia tem um custo bastante superior a vários países no continente sulamericano. Isso pode ser creditado, dentre outros fatores, à múltipla incidência de tributos gerais sobre o consumo nos produtos e serviços afetos à energia, mas também ao incremento do custo de conformidade ${ }^{49}$ das empresas do ramo em virtude da necessidade de apuração e recolhimento de diversos tributos de estrutura complexa.

\footnotetext{
${ }^{49}$ Aqui entende-se por "custos de conformidade" aqueles custos nos quais incorrem as empresas para adequar-se às exigências da legislação tributária, como contadores, advogados, sistemas de computador, dentre outros.
} 
Cabe salientar também que a incidência no Brasil de contribuições sociais (PIS/Pasep e Cofins) sobre a energia elétrica é um capítulo especial na dificuldade do processo de integração sul-americano. A participação das contribuições sociais na arrecadação federal foi incrementada nos anos 90 como um contraponto à perda de receitas para Estados e Municípios (BORDIN; LAGEMANN, 2006, p. 73) ${ }^{50}$. Isso porque, ao contrário dos impostos típicos e dos impostos residuais de competência da União, as contribuições sociais não se sujeitam à repartição com Estados, Distrito Federal e Municípios.

A Emenda Constitucional de Revisão $n^{0}$ 1/1994 criou o Fundo Social de Emergência, mais tarde convertido na Desvinculação de Receitas da União (DRU), mantida em vigor por diversas emendas seguintes, até a vigente Emenda Constitucional n ${ }^{\circ}$ 93/2016. A DRU desvincula 30\% das receitas federais de seus destinos legais e afeta principalmente as contribuições sociais. Assim, esses tributos passaram a ter conteúdo fiscal extremamente relevante para a União, muito embora desvinculados do seu propósito constitucional original.

A literatura atribui a essas contribuições baixa qualidade técnica, dada a tendência a gerar "efeitos cascata" na tributação do consumo (BORDIN; LAGEMANN, 2006, pp. 7374). No caso da tributação da energia, tal não é diferente, de modo que a União se utiliza de tributos de caráter fiscal relevante, assim como os Estados-membros. Outros países também o fazem, como já apontado anteriormente no caso do Uruguai. Contudo, essa dependência da tributação do consumo, no caso do Brasil, é redundante, pois acontece tanto no âmbito federal quanto dos Estados-membros e, no casos destes, com foco especial de dependência na tributação da energia (em média, 28,08\% da arrecadação de ICMS).

Outro problema é a criação do ICMS-Combustíveis de caráter monofásico e as restrições ao aproveitamento de créditos de ICMS-Energia Elétrica (que na prática o torna monofásico). Essas medidas tornam o ICMS um arremedo de tributo especial sobre o consumo de energia, pois lhe retiram atributos próprios da tributação geral, como o caráter plurifásico e não-cumulativo. Assim, não se aproxima do IVA dos demais países sulamericanos pesquisados, geral e plurifásico, mas sim dos tributos especiais sobre o consumo. Trata-se de outra distorção própria do sistema brasileiro.

Nesse sentido, o aumento da complexidade da legislação tributária importa em aumento dos custos de conformidade.

${ }^{50}$ Bordin e Lagemann (2006, p. 73) também apontam o incremento das CIDE na arrecadação federal como um defeito do sistema tributário pós-1988. Contudo, neste trabalho preferiu-se deixar de fora, neste ponto, o problema da CIDE-Combustíveis. Isso porque, na sistemática da tributação da energia, essa CIDE é o tributo que mais se assemelha a um tributo especial sobre o consumo. Assim, de fato tem lugar no contexto sul-americano, tomando por base os países comparados. Mais à frente, será retomado o debate específico sobre o papel da CIDE-Combustíveis. 
Há ainda que se chamar atenção às alíquotas do ICMS-Combustíveis de incidência monofásica. A alíquota desse tributo, como se viu, varia a depender do Estado tributante entre $25 \%$ e $30 \%$. Dos países pesquisados, é a alíquota mais alta dentre os tributos gerais sobre o consumo (os IVA's) ${ }^{51}$. Ressalte-se que trata-se de uma alíquota monofásica de alíquota superior às alíquotas plurifásicas de suas contrapartes sul-americanas. A ausência de um creditamento de ICMS nesses casos tem uma tendência a penalizar cadeias produtivas mais longas, pois o custo tributário da origem vai sendo repassado dentro da cadeia.

Em arremate desse ponto, o que se tem no Brasil é um sistema não apenas dependente, mas também redundante, de tributação da energia, carente de uma melhor coordenação entre as diversas imposições tributárias.

Levando-se em consideração esses aspectos, as múltiplas incidências de tributos gerais sobre o consumo incidentes sobre a energia no Brasil são aqui apontados como um entrave à integração energética.

\subsection{COMPETÊNCIA DOS ESTADOS-MEMBROS PARA TRIBUTAR A ENERGIA}

Outro aspecto que destaca o Brasil em relação aos demais países pesquisados é o fato de que a tributação da energia - na verdade, do consumo em geral - conta com relevante atribuição dos Estados-membros, por intermédio do ICMS. Nos demais países pesquisados, ou se trata de Estado unitário, no qual a tributação do consumo cabe ao poder político uno, ou se trata de Estado federal em que a tributação da energia cabe ao poder central. Não se observou hipótese em que poder subnacional tenha atribuição para tributar o consumo em geral ou sequer operações específicas afetas à energia, como o consumo de energia elétrica ou combustíveis.

Essa competência dos Estados para tributar operações que envolvem matéria de energia gera distorções relevantes. A primeira, e mais óbvia, é a elevada diferenciação de alíquotas incidentes sobre o mesmo produto a depender do Estado tributante. Como já se viu, em matéria de energia elétrica a diferença de alíquota pode chegar a doze pontos percentuais e em matéria de combustíveis (especificamente a gasolina) chega a cinco pontos percentuais.

Essa disparidade produz preços diferenciados por Estado. Ora, a aproximação dos custos de produção é um pressuposto da integração econômica. Se um dos Estados-partes no

\footnotetext{
${ }^{51}$ Nos demais países sul-americanos, há alíquotas maiores nos tributos especiais sobre o consumo de combustíveis, não no IVA. No caso brasileiro, há o acúmulo do ICMS monofásico, o PIS/Pasep e Cofins e o tributo especial, a CIDE. No Brasil, portanto, o que há é a incidência cumulativa com tendência monofásica de se acumular em cadeias longas.
} 
processo de integração não consegue alcançar uma harmonia mínima de custos entre seus próprios Estados-membros, tampouco poderá fazê-lo no âmbito internacional.

A segunda distorção é a ocorrência de guerra fiscal em matéria de energia.

Para Guilherme Bueno de Camargo (2004, p. 200), a guerra fiscal consiste na generalização de uma competição entre entes subnacionais pela alocação de investimentos privativos por meio da concessão de benefícios que envolvem renúncia fiscal, conflito esse que decorre de uma estratégia não cooperativa dos Estados-membros da Federação. No âmbito da tributação da energia, os incentivos fiscais em matéria de ICMS também configuram guerra fiscal e promovem uma desagregação entre os Estados, além de uma forte depreciação da base tributária.

A ocorrência da guerra fiscal promove efeitos específicos de distorção econômica quando se trata de energia. Tome-se como exemplo o fuel tankering ${ }^{52}$, um planejamento tributário das companhias aéreas que utiliza a diferenciação de alíquotas de querosene de aviação.

O querosene de aviação é um dos componentes mais relevantes do custo das companhias aéreas, variando entre $20 \%$ e $40 \%$ de seu custo total de operação. Há grandes diferenças nas alíquotas de querosene de aviação por Estado-membro. Em São Paulo e no distrito federal, a alíquota é de $25 \%$. Já no aeroporto de Confins, em Belo Horizonte, e do Galeão, no Rio de Janeiro, em virtude de incentivos fiscais, a alíquota do querosene de aviação é de $4 \%$.

Assim, se um avião vai partir de São Paulo a Brasília, é mais econômico à companhia aérea que o avião decole originalmente não de São Paulo, mas do Galeão, no Rio de Janeiro. Nesta decolagem, o avião abastece todo seu tanque a uma alíquota reduzida. Dessa forma, o fator tributário leva a empresa a criar uma nova escala no voo. É, noutros termos, uma situação em que o direito tributário condiciona as escolhas dos agentes econômicos.

Pode ser observado, portanto, que a guerra fiscal é um qualificador que aprofunda um problema autônomo, que a competência dos entes subnacionais para tributar a energia. A alocação de recursos energéticos e de negócios que dependem destes, nessa quadro, fica condicionada mais ao fator tributário do que a outras considerações de eficiência econômica.

Até aqui, o que se pode observar em comum às três críticas já desenvolvidas é a violação do princípio da neutralidade tributária. Tal princípio, derivado de uma abordagem

\footnotetext{
52 Dados disponíveis em: https://www.senado.gov.br/noticias/Jornal/emdiscussao/revista-em-discussao-ediaonovembro-2010/materias/guerra-fiscal-sobre-querosene-afeta-mais-as-empresas-de-aviaao-regionais.aspx, acessado em 10 de janeiro de 2017, às 12h30min.
} 
liberal do direito tributário, se apresenta em duas perspectivas (ELALI, 2007, p. 58). A primeira é que diz respeito à necessidade de se evitarem mudanças nos comportamentos dos agentes econômicos, de forma a manter o status próprio dos movimentos econômicos e sociais, ou seja, de que a tributação não deve intervir no mercado. A segunda diz respeito a uma conclusão de que nenhum tributo pode ser considerado neutro, porque terá sempre influência no contexto econômico e social.

A segunda perspectiva é na realidade uma constatação lógica. O tributo impõe um ônus econômico a determinadas condutas dos agentes econômicos. É lícito e factível, portanto, que os agentes econômicos planejem seu negócio de forma a ter ônus menores. Entretanto, ao instituir tributos, cabe ao Estado evitar distorcer de forma "não intencional" o funcionamento da economia.

A literatura econômica utiliza a expressão "agentes econômicos" para se referir aos atores que tomam decisões e formam um determinado mercado, geralmente os enumerando como "famílias", "empresas" e "Estado" ou "governo" (VASCONCELLOS, 2006, p.6). Contudo, em uma análise jurídica do conceito, é preciso fazer algumas constatações de forma crítica.

A teoria econômica coloca o Estado como um ator em um cenário maior - o mercado - tido este como um ente prévio e quase que natural. A mera existência do mercado, entretanto, demanda a existência do Estado que garanta o fluxo de capitais entre seus atores ${ }^{53}$. É preciso que o Estado garanta, por exemplo, a propriedade privada e a circulação da moeda.

Portanto, ao se falar de "neutralidade tributária" não se quer dizer que sua violação consiste na atuação estatal sobre uma vontade natural e pré-jurídica dos agentes econômicos, mas sim em uma intervenção desnecessária à mera existência do mercado. Além disso, a violação à neutralidade também ocorre se a atuação estatal não ocorre para dissolver efeitos alocativos indesejados.

Uma coisa é promover modificações na legislação tributária para reduzir determinadas desigualdades. Outra, completamente diferente, é causar distorções na agenda econômica dos particulares por razões meramente fiscais, no sentido de necessidade de suprimento de caixa do Estado. A integração regional demanda um processo econômico legítimo, entendido este como o que ocorre pelo funcionamento regular do mercado, sem distorções ou manipulações (ELALI, 2008, p. 65). As diferenças fiscais entre os Estados

\footnotetext{
${ }^{53}$ Eros Roberto Grau (2008, p. 35), aponta que "o mercado exige, para a satisfação do seu interesse, o afastamento ou a redução de qualquer entrave social, político ou moral ao processo de acumulação de capital. Reclama atuação estatal para garantir a fluência de suas relações, porém, ao mesmo tempo, exige que essa atuação seja mínima.”.
} 
soberanos e, no caso do Brasil, entre os Estados-membros, impõe condicionantes econômicos que reduzem o equilíbrio do desenvolvimento regional, dificultando a integração ao invés de promove-la.

Ainda sobre o ICMS, é preciso destacar os requintes de complexidade do tributo. Conforme se observou, a estrutura federativa do ICMS brasileiro por si só é complexa. Ainda assim, mesmo disposições legais uniformes ampliam sua complexidade e o afastam do modelo de IVA descrito nos demais países pesquisados.

A composição da base de cálculo do ICMS deve ser feita com a inclusão do montante do próprio imposto, o que se convencionou chamar de "cálculo por dentro do ICMS" (art. 13, $\S 1^{\circ}$, inciso I, da Lei Kandir) ${ }^{54}$. A inclusão do ICMS em sua própria base de cálculo importa em criação de um "tributo oculto", tornando desnecessariamente complexa e onerosa a base de cálculo da exação.

O ICMS, como tributo indireto sobre o consumo, tem um efeito inerente de anestesia fiscal, considerada esta como a falta de visibilidade do tributo que conduz o contribuinte de fato a suportá-lo sem se dar conta disso (BASTO, 1991, p. 28). Essa característica, somada à ocultação promovida pelo "cálculo por dentro", cria um sistema carente de equidade e transparência na tributação do consumo. Considerando-se que os produtos de energia têm demanda pouco elástica, tornam-se, estrategicamente, fontes de receitas para o Estado mediante as técnicas de ocultação de tributos e anestesia tributária.

Essa prática, contudo, não se coaduna com princípios democráticos e republicanos básicos de que os cidadãos têm direito a conhecer os passos e decisões de seus governantes. Além disso, do ponto de vista meramente econômico, as "camadas de mistério" na base de cálculo do ICMS aumentam os custos de conformidade das empresas.

Por fim, é preciso retomar a crítica do sistema brasileiro de atribuição de royalties ao Estado produtor e ICMS ao Estado consumidor de combustíveis ou energia elétrica. Essa política tende a gerar um elevado desequilíbrio financeiro e merece correção, muito embora a questão do equilíbrio federativo na distribuição de royalties seja meramente tangencial ao objeto do presente estudo.

A integração energética da América do Sul, portanto, demanda processos de coordenação ou harmonização tributária que enderecem o reforço da neutralidade tributária sobre a energia.

\footnotetext{
54 “Art. 13. A base de cálculo do imposto é: [...] $§ 1^{\mathrm{o}}$ Integra a base de cálculo do imposto, inclusive na hipótese do inciso V do caput deste artigo: I - o montante do próprio imposto, constituindo o respectivo destaque mera indicação para fins de controle;"
} 


\subsection{OS CRITÉRIOS DE ORIGEM E DESTINO NA TRIBUTAÇÃO DA ENERGIA}

Outro ponto que merece ser endereçado é a discussão sobre os critérios de origem e destino no comércio internacional de produtos de energia.

Os princípios de origem e destino na distribuição de competências tributárias no comércio internacional envolve uma discussão acerca da equidade e da eficiência. A equidade envolve a divisão correta e justa de receitas tributárias entre os Estados (GASSEN, 2013, p. 135). Por outro lado, a eficiência envolve a discussão acerca da anulação de distorções causadas pelos tributos e as necessidades de sua administração (GASSEN, 2013, p. 135). Trata-se de eficiência do ponto de vista da alocação de recursos.

Nos países pesquisados, observa-se uma tendência de tributar pelo IVA as operações internas, havendo uma imunidade ou isenção nas operações que destinam produtos ao exterior. Essa imunidade ou isenção implica, a princípio, a adoção do critério de destino nas relações comerciais. Nesses casos, é retirado o conteúdo fiscal do produto por ajustes fiscais de fronteira.

A opção pelo princípio de destino demanda a adoção de "ajustes fiscais de fronteira" (boarder tax adjustments), ou seja, a retirada da carga fiscal de determinado produto exportado, evitando a bitributação sobre ele pelos países de origem e destino (GASSEN, 2013, p. 145). Daí se dizer que a adoção do critério de destino exige a manutenção de barreiras fiscais entre os países partícipes do processo comercial.

Essa é a regra atualmente adotada. Entretanto, deve se levar em consideração, ao tratar do caso em exame, da conveniência ou não de manter a regra de tributação no destino tendo em conta três fatores: a existência do processo de integração regional no âmbito do Mercosul; a peculiaridade distributiva das fontes de energia e seu impacto na distribuição de receitas tributárias; a existência de tributos monofásicos de incidência especial sobre o consumo em matéria de combustíveis.

O processo de integração do Mercosul remonta ao Tratado de Assunção, o qual previu que é objetivo do bloco o estabelecimento de um programa de liberalização comercial, que consiste de reduções tarifárias progressivas, lineares e automáticas acompanhadas da eliminação das barreiras não tarifárias. $\mathrm{O}$ artigo 1 do Tratado prevê que o mercado comum implica "a livre circulação de bens, serviços e fatores produtivos entre os países, através, entre outros, da eliminação dos direitos alfandegários e restrições não tarifárias à circulação de mercadorias e de qualquer outra medida de efeito equivalente". 
Logo se vê que o Mercosul busca um processo gradual de liberalização comercial. Pode-se argumentar, por outro lado, que a adoção do critério de destino na tributação do comércio entre os Estados-membros é um óbice a esse processo.

Isso porque o princípio de destino, como já aduzido, demanda a manutenção de barreiras fiscais em virtude da necessidade de ajustes fiscais de fronteira. O princípio que melhor responderia para promover a integração, portanto, seria o princípio da origem. A ausência de barreiras fiscais possibilitada pelo critério da origem permite que os produtos originários de todos os países do bloco circulem de forma livre e desembaraçada, promovendo a unificação dos mercados nacionais em um mercado regional.

A adoção do princípio de origem, contudo, demanda processo de harmonização ou coordenação dos fiscos nacionais. Isso porque diferenças substanciais no montante da incidência tributária podem inviabilizar determinadas relações comerciais. É dizer: um Estado com uma alíquota superior de IVA jamais teria a oportunidade de exportar para um Estado com alíquota inferior. A adoção do critério de origem, portanto, demanda harmonização intensa para garantir a neutralidade tributária.

Além disso, a adoção do princípio de origem pode implicar em dificuldades de ordem financeira aos Estados em processo de integração. Os Estados exportadores receberão proporcionalmente mais receitas tributárias que os importadores. Ainda assim, os exportadores poderiam ter problemas com suas exportações em virtude da oneração tributária que acabariam praticando, prejudicando sua balança comercial.

Trata-se, como se vê, de fator cujas considerações são de elevada complexidade.

$\mathrm{O}$ fato de tratar-se com comércio de energia torna ainda mais complexo o problema. Conforme se discutiu quando da descrição do sistema tributário brasileiro, as fontes de energia elétrica de potencial hidráulico, por exemplo, estão localizadas em locais de geografia favorável. Da mesma forma, as reservas de petróleo e gás natural se concentram em determinados locais, sem qualquer uniformidade necessária entre os países.

Nessa situação, a adoção do critério de origem pode favorecer com maiores receitas tributárias os países detentores dos potenciais energéticos, de forma a aumentar eventuais desigualdades regionais já existentes. Tratar-se-á, portanto, de um fator de desagregação do bloco em virtude do desenvolvimento desequiparado entre os Estadosmembros.

Doutra banda, os Estados-partes que consomem os produtos de energia podem se ver sem qualquer recompensa fiscal em razão dos prejuízos do consumo energético. É o caso, por exemplo, do consumo de derivados de petróleo que levam um grande passivo ambiental. 
Posto esse quadro, tem-se uma possível contraposição entre a integração regional - decorrente da adoção do princípio da origem - e a justiça na distribuição da arrecadação fiscal na tributação do consumo de energia - decorrente do princípio do destino. Como se vê, trata-se de uma contraposição entre eficiência (origem) e equidade (destino) que demanda resolução.

Quando se fala em tributação do consumo, em especial nos problemas até agora expostos, tende-se a chamar atenção ao IVA, por ser um tributo geral sobre o consumo de relevância. Entretanto, outro fator se mostra importante na discussão: os tributos especiais sobre o consumo, notadamente incidentes sobre combustíveis.

Os tributos especiais, em processos de integração energética, têm o potencial de causar conflitos entre sistemas tributários. Ao contrário do IVA, os tributos especiais muitas vezes têm caráter monofásico, de modo que incidem em momentos específicos da cadeia.

No caso de adoção do princípio de destino, tratando-se de tributos monofásicos, é fácil a apuração e desagravamento dos produtos objeto de exportação, de modo que não se apresentam nesse caso maior problemas (GASSEN, 2013, pp. 158-159). Entretanto, o momento escolhido para a incidência do tributo (seu critério temporal) pode oferecer dificuldades. Por exemplo, pode ser escolhido o momento da produção (ou exploração), distribuição ou consumo final, no caso de produtos de energia.

O tributo que melhor se coaduna com o princípio de destino é aquele cujo critério temporal está no consumo final, porque é possível a precisa apuração da carga fiscal, o que facilita o ajuste fiscal de fronteira. No caso de incidência na produção ou exploração, por outro lado, dificulta-se a apuração do tributo, pois esse incidiu sobre valor menor do que ocorreria no caso de tributação no momento do consumo (GASSEN, 2013, p. 160).

Essa distorção pode causar favorecimento às importações em detrimento das exportações.

No caso do princípio da origem, a incidência de tributos especiais sobre o consumo pode causar também distorções. Isso porque o exportador aplicará o tributo em seu território e, em virtude da ausência de barreiras fiscais, o Estado importador não terá possibilidade de realizar ajustes fiscais (GASSEN, 2013, p. 174). Assim, Estados com menor incidência tributária são beneficiados em suas exportações em detrimento de Estados com maior incidência. Esse cenário prejudica a neutralidade tributária na relação comercial entre tais Estados, o que precisa ser corrigido.

Sobre os Estados pesquisados, veja-se a seguinte tabela: 
Tabela 4 - Tributos especiais sobre o consumo de energia na América do Sul

\begin{tabular}{|c|c|c|c|}
\hline Estado & Tributo & Critério Material & Critério Temporal \\
\hline Brasil & $\begin{array}{l}\text { CIDE- } \\
\text { Combustíveis }\end{array}$ & $\begin{array}{l}\text { Importação e comercialização } \\
\text { de petróleo e derivados. }\end{array}$ & $\begin{array}{l}\mathrm{Na} \text { importação ou comercialização no } \\
\text { mercado interno. }\end{array}$ \\
\hline Argentina & $\begin{array}{l}\text { Imposto } \\
\text { especial sobre } \\
\text { combustíveis e } \\
\text { gás }\end{array}$ & $\begin{array}{l}\text { Importação e comercialização } \\
\text { de combustíveis e gás natural. }\end{array}$ & $\begin{array}{l}\mathrm{Na} \text { importação ou comercialização, bem } \\
\text { como na entrada da rede de distribuição, no } \\
\text { caso de gás natural. }\end{array}$ \\
\hline Paraguai & $\begin{array}{l}\text { Imposto } \\
\text { seletivo } \\
\text { consumo }\end{array}$ & $\begin{array}{l}\text { Importação ou comercialização } \\
\text { de combustíveis derivados de } \\
\text { petróleo. }\end{array}$ & Na importação ou primeira venda. \\
\hline Uruguai & IMESI & $\begin{array}{l}\text { Importação ou comercialização } \\
\text { de combustíveis. }\end{array}$ & Na importação ou primeira venda. \\
\hline Venezuela & ICP e ICG & $\begin{array}{l}\text { Venda de produtos derivados } \\
\text { de petróleo. }\end{array}$ & $\begin{array}{l}\text { No fornecimento ao consumidor, seja para } \\
\text { consumo próprio (ICP) ou de consumidor } \\
\text { final (ICG). }\end{array}$ \\
\hline Bolívia & IEDH e IDH & $\begin{array}{l}\text { Importação ou comercialização } \\
\text { de derivados de } \\
\text { hidrocarbonetos (IEDH) ou a } \\
\text { exploração dos mesmos (IDH). }\end{array}$ & $\begin{array}{l}\mathrm{Na} \text { importação ou primeira venda (IEDH) } \\
\text { ou no momento da exploração (IDH). }\end{array}$ \\
\hline Chile & $\begin{array}{l}\text { Imposto sobre } \\
\text { combustíveis }\end{array}$ & $\begin{array}{l}\text { Importação ou comercialização } \\
\text { de combustíveis. }\end{array}$ & Na importação ou primeira venda. \\
\hline
\end{tabular}

Como se pode observar, os tributos especiais sobre o consumo na América do Sul são via de regra monofásicos e devidos na importação ou comercialização (ou primeira venda). Exceção importante é a Bolívia, que tributa a própria exploração de hidrocarbonetos.

O Brasil desonera da incidência da CIDE-Combustíveis as exportações. Outros países, como Paraguai, Uruguai, Bolívia e Chile, tributam o produto apenas na primeira venda.

O que se observa, portanto, é a adoção do critério de destino para a maioria dos tributos especiais sobre o consumo, de modo que a preocupação do legislador deve ser possibilitar da forma mais clara e simples o desagravamento de tais exportações. Mas, nesse ponto, também se torna pertinente a discussão já travada quanto ao papel dos critérios de origem ou destino na integração regional.

Há, por outro lado, casos pontuais de incidência monofásica em momentos anteriores ao consumo, como é o caso do imposto argentino sobre gás, que incide no momento da entrada do produto na rede de distribuição. Outro exemplo é o IDH boliviano, que incide no momento da exploração dos bens. Essas hipóteses dificultam o desagravamento dos produtos de energia e podem se mostrar como óbices ao processo de integração.

Exposta a problemática, no capítulo a seguir serão propostas modificações legislativas - tomando como referência o Brasil e seu processo de integração no Mercosul para sanar os óbices encontrados. 


\section{PROPOSTA DE ALTERAÇÕES DA LEGISLAÇÃO BRASILEIRA PARA PROMOÇÃO DA INTEGRAÇÃO ENERGÉTICA}

No capítulo 3 deste trabalho, foram abordados conceitos essenciais no marco teórico adotado em relação aos conceitos de coordenação e harmonização tributária. No presente trecho deste trabalho, serão aplicados esses conceitos à situação específica analisada no capítulo 4: as disparidades sistêmicas tributárias na América do Sul que dificultam a integração energética.

Para tanto, é preciso, primeiramente, fazer-se uma opção pelos mecanismos a ser utilizados. Foi dito que a coordenação tributária, ao contrário da harmonização, visa apenas mitigar os efeitos da justaposição de sistemas tributários. A harmonização, por outro lado, visa atacar as causas estruturais, aproximando, de forma propriamente dita, os diversos sistemas tributários.

É possível indagar, ante a diferença conceitual, qual seria a política mais adequada à integração energética: a coordenação ou a harmonização. A resposta a essa indagação passa pela comparação da experiência da integração energética europeia e sul-americana.

Como se viu no capítulo 2, a integração energética europeia se deu em um contexto mais amplo de integração comercial regional, a Comunidade Europeia. Mais que um processo mais amplo, é preciso destacar que o que ocorreu no velho continente foi um processo multilateral de integração energética. Ao contrário, na América do Sul, as iniciativas de integração energética foram historicamente pontuais e bilaterais. Sequer a experiência de integração energética sul-americana seguiu os passos da integração regional.

Com efeito, tomando-se por base uma experiência exitosa de integração energética, é forçoso concluir que a integração regional multilateral tem se mostrado uma experiência de sucesso em detrimento da mera integração bilateral que vem sendo aplicada.

Ademais, a integração em vários âmbitos de vários Estados parece ser menos arriscada do ponto de vista da soberania energética do que a mera integração bilateral. Ora, de um lado, a integração energética bilateral pode gerar uma relação de dominância/dependência energética de um Estado a outro, comprometendo de forma essencial a soberania de um deles. Mas, se ocorrida uma integração em diversos âmbitos e de caráter regional, é maior a chance de mitigação mais equilibrada e menos violenta, e não eliminação, das soberanias nacionais.

Por esses fatores, conclui-se que a opção por uma integração energética que acompanhe a integração econômica regional é mais adequada. Para tanto, conforme já 
exposto, são mais adequados mecanismos de harmonização tributária do que de mera coordenação, pois é aquela que promove a efetiva integração de economias.

Dentre os processos de harmonização, podem ser destacadas a uniformização, a compatibilização e a instrumentação. A seguir, serão delimitadas propostas de alteração legislativa e, quando pertinente, realizada a classificação delas dentro dos diversos processos de harmonização possíveis.

\subsection{UNIFICAÇÃO E CENTRALIZAÇÃO DA TRIBUTAÇÃO GERAL SOBRE O CONSUMO NO BRASIL}

O problema da desarmonia - interna e externa - da tributação sobre o consumo no Brasil, conforme já apontado, é um óbice à integração regional. A necessidade de correção desse problema, mediante a unificação e federalização dos tributos incidentes sobre o consumo, transborda a questão da integração energética, chegando à discussão sobre a eficiência do sistema tributário em si. Na verdade, a necessidade de instituição de um IVA federal no Brasil já foi apontada em diversos trabalhos anteriores a este (DERZI, 1998; LAGEMANN, 1998; LEONETTI, 2007; SALDANHA, 2008, p. 192, por exemplo).

Por unificação da tributação geral sobre o consumo, entende-se aqui a extinção dos atuais tributos ICMS, PIS/Pasep e Cofins ${ }^{55}$ com a substituição por um único tributo que seja plurifásico e não cumulativo. Essas características indicam a necessidade de uma instituição de um IVA. A unificação é necessária para reduzir o custo de conformidade dos contribuintes, além de aproximar o modelo brasileiro aos demais países da América do Sul pesquisados. É essencial, inclusive, que se adote um tributo geral sobre o consumo de regime plurifásico e não cumulativo, nos termos dos demais IVA adotados na região.

Os demais países, em matéria de tributação da energia, em geral adotam um IVA (imposto geral) e um imposto especial sobre o consumo de energia elétrica ou combustíveis. Essa sistemática permite ao órgão central de governo efetivamente arrecadar, bem como, mediante o tributo especial, regular o mercado energético. No Brasil, a redundância de diversos impostos gerais dificulta, quando não impossibilita, a utilização dos tributos especiais sobre o consumo com caráter extrafiscal.

\footnotetext{
${ }^{55}$ Mencionam-se aqui apenas o ICMS, PIS/Pasep e Cofins porque são incidentes sobre a energia. Contudo, no debate mais amplo sobre a tributação do consumo, devem ser inseridos nessa lista o Imposto sobre Produtos Industrializados (IPI) e Imposto sobre Serviços de Qualquer Natureza (ISS).
} 
Há autores, como Misabel Derzi (1998, pp. 29-30) que entendem ser desnecessária uma modificação constitucional profunda no ICMS para permitir a integração regional no Brasil. Para a autora, bastar-se-ia adotar internamente o princípio de destino nas operações interestaduais e permitir a manutenção de créditos de ICMS nas operações de exportação ${ }^{56}$.

Discorda-se da posição da autora, pois o que aqui se discutiu foi a redundância e complexidade da tributação da energia no Brasil, em virtude da incidência de tributos estaduais e federais sobre o consumo. Para se resolver essa problemática, se faz necessária a unificação desses tributos. Tal unificação somente pode ser realizada pela via da emenda constitucional.

A unificação da tributação sobre o consumo, em especial sobre a incidência sobre a energia, leva a uma discussão federativa financeira. O ICMS é a principal fonte de receitas tributárias dos Estados e do Distrito Federal. As incidências sobre energia elétrica e combustíveis, como já exposto, consistem em quase um terço da arrecadação desse imposto. O PIS/Pasep e a Cofins, por sua vez, consistindo em contribuições sociais, são receitas relevantes para a seguridade social (muito embora a existência da DRU possa militar contra essa afirmativa).

A eventual unificação, portanto, não pode passar ao largo da discussão sobre a destinação de receitas desse novo tributo sobre o consumo para os entes subnacionais e para a seguridade social. Os limites temáticos do presente trabalho, entretanto, não permitem aprofundamento acerca desse ponto.

Pode-se apontar, como alternativa à modificação constitucional, a utilização da faculdade prevista no art. $155, \S 4^{\circ}$, inciso IV, da Constituição Federal, para que o Confaz fixe alíquotas uniformes e incidência monofásica do ICMS-Combustíveis, ou seja aprovada lei complementar nesse sentido pelo Congresso Nacional. Nessa hipótese, haveria ao menos alíquotas uniformes do tributo, reduzindo o prejuízo à neutralidade tributária. Contudo, esse caminho não resolveria o problema da tributação redundante pelo PIS/Pasep e Cofins, salvo se sobre essas contribuições fosse criada hipótese de isenção. Este isenção sobre a energia, por outro lado, importaria em necessidade de medidas de compensação de receita para a seguridade social.

\footnotetext{
${ }^{56} \mathrm{O}$ art. $155, \S 2^{\circ}$, da Constituição Federal, prevê que, salvo legislação em contrário, a isenção ou não incidência do ICMS não implicará em crédito para as operações posteriores e acarretará a anulação do crédito relativo às operações anteriores. Esse óbice apontado pela autora foi superado pela Emenda Constitucional n ${ }^{\circ} 42 / 2003$ e pela Lei Complementar $\mathrm{n}^{\circ}$ 120/2005, que passaram a garantir a manutenção dos créditos de ICMS decorrentes de operações que destinem produtos ao exterior.
} 
Outro problema da via infraconstitucional é que, embora haja constitucionalmente a previsão de mecanismos de uniformização de alíquotas para o ICMS-Combustíveis, o mesmo não há para o ICMS-Energia Elétrica, cujas alíquotas, constatou-se, variam em maior amplitude do que no caso da incidência sobre combustíveis.

Por centralização entende-se a atribuição de competência legislativa para tributação geral sobre o consumo no âmbito da União. Como se demonstrou, a disparidade de alíquotas de ICMS entre os vários Estados dá azo à guerra fiscal entre eles, além de abrir espaço para planejamentos tributários decorrentes da violação ao princípio da neutralidade tributária, como o fuel tankering.

Fala-se de centralização - e não de federalização - porque o relevante é proporcionar uma medida que concentre em âmbito federal competência legislativa para tributação sobre o consumo, não necessariamente a receita pública dela decorrente. É dizer: não necessariamente o eventual IVA deve ser federal, no sentido de um tributo com receitas da União, mas basta que a legislação que o disciplina seja decorrente de legislação federal. Um exemplo de Estado que adota IVA de administração regional, mas com legislação uniforme federal, é a Alemanha.

No caso da Alemanha, a própria Constituição dispõe sobre a prevalência da legislação federal em detrimento da legislação estadual (BACHUR, 2005, pp. 385-386). Naquele país, há previsão específica de que a legislação federal prevalece sobre a estadual. Ao mesmo tempo, há atribuição dos Estados (Länder) para aplicar a legislação federal, em um modelo de federalismo fiscal cooperativo. É exatamente o que ocorre no caso do IVA alemão: a legislação é federal, uniforme, mas a sua administração cabe aos Estados, assim como a arrecadação ${ }^{57}$.

Conforme salienta Luiz Alberto Gurgel de Faria (2010, p. 212), em tese de doutoramento sobre o papel da extrafiscalidade na redução das desigualdades regionais, a ideia de um federalismo fiscal procura distinguir encargos e competências administrativas com receitas públicas equivalentes entre os entes federativos, permitindo que as demandas sociais sejam supridas. A demanda por serviços públicos é crescente e gera constantemente conflitos no sistema cooperativo, o que acaba gerando o efeito de guerra fiscal. O que salienta

\footnotetext{
57 “Como contraponto à concentração de competências legislativas nas mãos da União - e caracterizando a assimetria do federalismo germânico -, a Constituição de Bonn disciplina a execução administrativa da legislação federal e a administração pública federal, tarefas deixadas a cargo dos Länder como 'matéria própria', conforme disposto no artigo 83 da Lei Fundamental." (BACHUR, 2005, p. 386).
} 
o autor é que esse cenário de federalismo competitivo é incompatível com uma concepção cooperativa de federação, cabendo ao Governo Central evitar essa competição.

Nesse sentido, pode ser idealizado um IVA brasileiro cuja legislação seja de competência da União, mas cuja administração e receita seja voltada total ou parcialmente aos Estados e Distrito Federal. Esse modelo congregaria a necessidade de manutenção de receitas dos entes subnacionais com a uniformidade nacional da tributação do consumo. Além disso, conferiria à União um instrumento de promover um federalismo cooperativo e arbitrar as disputas fiscais dos entes subnacionais.

É certo que, por aplicação do art. $155, \S 2^{\circ}$, XII, da Constituição Federal, cabe a lei complementar nacional, acerca do ICMS, definir seus contribuintes; dispor sobre substituição tributária; disciplinar o regime de compensação do imposto; fixar, para efeito de sua cobrança e definição do estabelecimento responsável, o local das operações relativas à circulação de mercadorias e das prestações de serviços; excluir da incidência do imposto, nas exportações para o exterior, serviços e outros produtos; prever casos de manutenção de crédito, relativamente à remessa para outro Estado e exportação para o exterior, de serviços e de mercadorias; regular a forma como, mediante deliberação dos Estados e do Distrito Federal, isenções, incentivos e benefícios fiscais serão concedidos e revogados; definir os combustíveis e lubrificantes sobre os quais o imposto incidirá uma única vez, qualquer que seja a sua finalidade, e fixar a base de cálculo, de modo que o montante do imposto a integre, também na importação do exterior de bem, mercadoria ou serviço. Atualmente, tal papel é desempenhado pela Lei Kandir.

A legislação nacional sobre ICMS, contudo, é deficiente em um ponto fundamental: não permite uniformização de alíquotas, salvo no caso de combustíveis derivados de petróleo, o que gera distorções internas no preço da energia, como já demonstrado neste trabalho. Faz-se necessária, portanto, reforma constitucional que permita a uniformização de alíquotas incidentes sobre a energia, especialmente a energia elétrica.

Até o presente momento, as soluções apontadas podem ser classificadas como instrumentos de harmonização por uniformização legislativa, pois o que se busca é aproximas o sistema brasileiro de tributação da energia dos demais sistemas pesquisados na América do Sul.

Acima, consignou-se que os tributos especiais sobre o consumo na América do Sul são via de regra monofásicos e devidos na importação ou comercialização (ou primeira venda). Exceção importante é a Bolívia, que tributa a própria exploração de hidrocarbonetos, e a Argentina, que tributa a canalização de gás. Pode-se dizer que os tributos especiais sobre o 
consumo têm estrutura razoavelmente uniforme, sendo sua problemática a discutir a questão da incidência na origem ou no destino.

Por essa razão, os tributos especiais sobre o consumo não têm necessidade premente de ser objeto de uniformização. Na verdade, podem se tornar meios de instrumentação na harmonização legislativa.

Ainda que uniformizado e centralizado no âmbito brasileiro um eventual IVA, nota-se que seus congêneres no Mercosul têm alíquotas díspares. Também na Bolívia, na Venezuela e no Chile há variação de alíquotas em relação aos demais países pesquisados. Isso decorre das necessidades fiscais de cada Estado soberano. O sistema de seguridade social do Uruguai, por exemplo, tem forte dependência da tributação sobre o consumo.

Essas necessidades fiscais podem influir negativamente no processo de uniformização de alíquotas dos diversos IVA incidentes sobre a energia na região. A uniformização nas alíquotas regionais - especialmente nos Estados-partes do Mercosul - é imprescindível à neutralidade tributária, pois permitirá a equalização dos custos de investimento no bloco.

Os tributos especiais sobre o consumo da energia, portanto, podem ser utilizados como instrumentos para uniformizar a carga tributária incidente sobre a energia no bloco, notadamente em matéria de combustíveis. A elevação ou redução das alíquotas desses tributos especiais pode ser utilizada para neutralizar os efeitos de alíquotas desequiparadas de IVA. Ademais, é importante observar que o caráter monofásico dos tributos especiais sobre o consumo de combustíveis facilita a aferição do peso tributário sobre o os produtos, o que favorece seu uso como meio de harmonização por instrumentação ${ }^{58}$.

Em suma, portanto, há de se sintetizar: muito embora não haja de forma taxativa uma necessidade de uniformização da tributação especial sobre o consumo de energia, há uma oportunidade de seu manejo para fins de instrumentação, o que consiste em outra forma de harmonização legislativa.

$\mathrm{Na}$ maioria dos países pesquisados ${ }^{59}$, a tributação especial sobre o consumo tem forte conteúdo extrafiscal de mitigação dos malefícios ambientais e sociais do consumo de combustíveis. Assim, é fiscalmente menos prejudicial aos Estados-partes do Mercosul equiparar cargas tributárias por intermédio dos tributos especiais do que por intermédio do

\footnotetext{
${ }^{58}$ Outra técnica possível seria a utilização de créditos presumidos em operações de importação ou exportação para fins de equalização de cargas tributárias. Seria, contudo, exemplo de coordenação legislativa e não harmonização propriamente dita.

${ }^{59}$ Viu-se que na Bolívia a tributação de hidrocarbonetos é fiscalmente muito relevante.
} 
IVA. Nesse aspecto, portanto, os tributos especiais podem se tornar relevantes indutores de integração energética regional no Mercosul.

\subsection{MANUTENÇÃO DO PRINCÍPIO DE DESTINO NA TRIBUTAÇÃO DA ENERGIA}

A discussão acerca da adoção dos princípios da origem e do destino é uma questão de análise de equidade e eficiência. Por outro lado, é preciso se levar em conta os efeitos da adoção de cada princípio jurisdicional no processo de integração regional.

A análise da questão, portanto, deve passar por três pontos: a adoção do princípio da origem ou destino nas relações comerciais entre os Estados pesquisados; a adoção desse mesmo princípio levando em consideração as peculiaridades dos produtos de energia; a adoção de um princípio jurisdicional para os tributos especiais sobre o consumo.

Já se apontou que o princípio da origem favorece a integração regional, pois remove a necessidade de ajustes fiscais de fronteira. Por outro lado, no comércio internacional fora de um contexto de integração regional, é conveniente ser adotado o princípio do destino.

A literatura, por sua vez, sugere para a redução dos ruídos gerados nos processos de integração a adoção do chamado princípio da origem restrito ${ }^{60}$ (GASSEN, 2013, p. 153). Nesse desenho estrutural, são distintas duas situações: relações entre Estados-partes de um bloco regional e relações com Estados estranhos ao bloco. Na relação intra-bloco, é adotado o princípio de origem, enquanto na relação extra-bloco é adotado o princípio de destino.

A vantagem desse esquema organizacional é combinar as razões de equidade e eficiência ínsitas a cada princípio. Se, por um lado, é garantido o livre comércio no espaço integrado com eliminação de fronteiras fiscais, há a manutenção destas em relação aos Estados de fora do bloco.

Em matéria de energia a adoção do princípio de origem tem a possibilidade de levar a uma iniquidade acentuada. Os potenciais energéticos são definidos pela natureza, em regra, como os potenciais de geração hidrelétrica e as reservas de petróleo e gás natural. $\mathrm{O}$ potencial exportador de um determinado Estado, portanto, pode ser substancialmente incrementado em relação a outro.

\footnotetext{
${ }^{60} \mathrm{Na}$ realidade, José Guilherme Xavier de Basto (1991, p. 78) entende que a adoção irrestrita do princípio de origem somente se pode considerar como solução universal na teoria. Na prática, somente pode ocorrer em espaços integrados, de modo que o autor considera o princípio de origem restrito seria o único cenário concebível de aplicação prática do princípio da origem.
} 
A tributação de produtos de energia na origem, portanto, pode gerar um incremento das receitas tributárias no Estado explorador em detrimento do Estado consumidor. Este último, inclusive, suportará parte do passivo ambiental decorrente do consumo de energia, como a poluição do ar em virtude da queima de derivados de petróleo.

Há também a questão da soberania energética. Ainda que determinados Estados se situem em um espaço de integração, a tributação na origem mitiga a possibilidade do Estado consumidor regular a dependência da sua matriz energética em relação ao vizinho exportador. Ocorre, assim, uma verdadeira mitigação da soberania energética de um Estado em processo de integração.

O que há é um conflito entre a soberania energética e a segurança energética propriamente dita. Por mais que a adoção do princípio da origem proporcione segurança energética na medida em que promove a interconexão de fluxos energéticos, prejudica o controle soberano da matriz energética do Estado.

A mitigação da soberania energética nessa situação escapa até mesmo às demais mitigações inerentes ao processo de integração. O efeito é tanto econômico quanto na própria soberania do Estado.

Adotar o princípio da tributação na origem em matéria da energia implicaria, portanto, em equiparar razões de eficiência - que militam a favor da medida - em face de razões de justiça e soberania. As razões do processo de integração, como qualquer outra medida tomada pelos Estados, devem envolver o aumento do bem-estar do seu povo e dos cidadãos dos demais Estados. $\mathrm{O}$ incremento da injustiça e da insegurança têm o condão de aumentar a tensão regional e, por via transversa, acaba por dificultar o processo de integração ao invés de promove-lo.

É importante destacar, conforme já exposto, que sequer o modelo de integração europeu logrou êxito em adotar o princípio da tributação na origem. O sistema unificado europeu adota ainda o princípio de destino, embora preveja medidas para mitigar os efeitos deletérios do princípio do destino no processo de integração. ${ }^{61}$

Por essas razões, entende-se que, em que pese a possível vantagem na tributação geral sobre o consumo, não deve ser adotado o princípio jurisdicional da origem, seja de

\footnotetext{
${ }^{61}$ Embora a adoção do regime transitório europeu seja encarada como positiva por Abel Alexandre Vilaça Dias, o mesmo autor também tece críticas à sua manutenção irrestrita, pois traz óbices à integração, como a dificuldade na localização dos compradores de bens e tomadores de serviços, dificuldade na tributação de operações triangulares e a circulação irrestrita e não tributada de bens antes de chegar ao destino (DIAS, 2004, pp. 52-67). Assim, Dias entende que a adoção do princípio de tributação na origem ainda é o ideal, mas para sua adoção devem ser tomadas providências como a aproximação cada vez maior das alíquotas nacionais de IVA, a criação de um sistema de compensação e o combate a distorções concorrenciais (DIAS, 2004, pp. 63-70).
} 
forma integral ou restrita, na tributação da energia. O princípio que melhor atende a considerações de equidade e soberania é o princípio de destino. Essa opção parece um equilíbrio satisfatório entre a soberania e a segurança energéticas.

Outra questão que deve ser abordada é a qual o princípio jurisdicional que deve ser adotado na tributação especial sobre o consumo. Ao contrário da tributação geral mediante IVA - a qual é plurifásica e não cumulativa - os países pesquisados em geral utilizam uma sistemática de incidência monofásica dos tributos especiais sobre o consumo. Essa incidência monofásica deve ser considerada na eleição da principiologia de tributação internacional.

Por outro lado, os tributos especiais sobre o consumo, como já abordado, têm funções extrafiscais relevantes. Experiências de Estados membros da OCDE indicam a utilização de tributos especiais sobre combustíveis, por exemplo, por razões ambientais, incentivando a utilização de gasolina "enviromental-friendly" e de GLP por intermédio do acréscimo de preços de outros congêneres ambientalmente mais agressivos (OCDE, 2016, p.126).

Também no caso da Argentina, a tributação especial sobre combustíveis tem por objetivo permitir a regulação do mercado, bem como compensar externalidades ambientais negativas. No Brasil, a própria Constituição prevê como destino das receitas da CIDECombustíveis o pagamento de subsídios a preços ou transporte de álcool combustível, gás natural e seus derivados e derivados de petróleo; financiamento de projetos ambientais relacionados com a indústria do petróleo e do gás; financiamento de programas de infraestrutura de transportes.

A necessidade de utilização dos tributos especiais em políticas regulatórias e compensação de externalidades negativas leva à conclusão necessária de que deve ser adotado o princípio de destino na hipótese de operações internacionais. Isso porque é o Estado em que ocorre o consumo que terá necessidade de desenvolver objetivos extrafiscais na tributação da energia.

Adotar o princípio de origem em tributos especiais implicaria em retirar do Estado importador a competência regulatória por tributação extrafiscal. Dessa forma, ficaria com o Estado exportador o poder de delimitar os termos da política energética do Estado importador, em franco prejuízo da soberania energética deste.

Além disso, a tributação especial na origem deixaria sem cobertura financeira sobre externalidades negativas - em especial ambientais - o Estado de destino. Ora, o Estado explorador de petróleo, gás e derivados, em regra é remunerado por royalties ou outra verba congênere (como é o caso do Brasil e da Bolívia). Esses royalties também têm a função de 
compensar externalidades negativas do processo de exploração. Por outro lado, o Estado consumidor necessidade de receitas tributárias decorrentes da tributação especial para compensar as externalidades decorrentes do consumo de combustíveis.

Por essas razões, entende-se ser necessária a manutenção do princípio de destino na tributação especial sobre o consumo.

Não bastasse isso, anteriormente foi colocado neste trabalho que os tributos especiais, por seu caráter eminentemente extrafiscal, podem ser utilizados a par do IVA para uniformizar os níveis de alíquotas incidentes sobre produtos de energia. Trata-se de um mecanismo de harmonização por instrumentação.

Para que essa instrumentação seja de fato efetiva, é necessária a adoção do mesmo critério tanto na tributação geral quanto na especial, sob pena de gerar disparidades no comércio internacional de energia. Como também se optou neste trabalho pelo critério de destino na tributação geral, é tanto correta como conveniente a adoção desse mesmo princípio na tributação especial.

Por fim, cabe destacar que, no contexto dos Estados pesquisados, os ajustes fiscais de fronteira não encontram maiores dificuldades para ser realizados. Isso porque, à exceção da Venezuela (que tributa o consumo próprio da empresa exploradora de hidrocarbonetos) e da Bolívia (que tributa a própria exploração de gás pelo IDH), os Estados pesquisados tributam monofasicamente a primeira venda de combustíveis e derivados, de modo que não há maior complexidade no cálculo da carga tributária que deve ser eliminada no processo de exportação.

Em conclusão deste capítulo, opina-se pela manutenção do critério de destino como definidor da jurisdição tributária em matéria de energia. 


\section{CONCLUSÃO}

A crescente demanda por energia tem forçado sobremaneira os recursos naturais dos Estados, obrigando-os a rever suas matrizes energéticas e a estabelecer diretrizes regulatórias mais severas sob pena de prejudicar o meio ambiente de forma irreparável. Os custos dessa energia também têm se mostrado cada vez mais relevantes na dinâmica econômica mundial.

O enfrentamento de problemas comuns é justamente o que promove a integração regional entre Estados soberanos, não sendo diferente o caso do Mercado Comum do Sul Mercosul. Daí porque a integração energética entre os Estados-partes do Mercosul se mostra tema relevante. O processo de integração envolve a possibilidade de livre circulação da energia, favorecendo o intercâmbio energético e a formação de cadeias produtivas regionais no bloco.

O presente trabalho, portanto, buscou investigar os óbices tributários à integração energética da América do Sul. Tomou-se por base a análise das estruturas tributárias dos Estados-partes do Mercosul, bem como a Bolívia, a Venezuela e o Chile, em razão da relevância comercial que esses países têm para a economia brasileira.

Os óbices tributários se concentram, principalmente, na disparidade entre os diversos regimes de tributação da energia, o que nada mais é do que uma modalidade de tributação do consumo. A técnica proposta para a superação dos óbices encontrados é a harmonização legislativa em matéria tributária.

O início da investigação passou primeiro pela conceituação teórica da integração energética: o processo de interconexão estratégica das redes de energia em corredores nacionais, regionais ou internacionais que permitam, sob um âmbito normativo comum e serviços adequados, a circulação ágil e eficiente de energia dentro de determinado espaço de integração. Esse processo, demonstrou-se, ocorreu de formas diversas em espaços de integração no mundo.

Foi descrito o processo histórico de integração energética na Europa e na América do Sul. Uma constatação relevante na comparação entre os dois processos é que o da União Europeia se mostrou essencialmente multilateral, enquanto o sul-americano se deu de forma bilateral entre os Estados envolvidos. O processo europeu, diferentemente do que ocorreu na América do Sul, demandou, então, harmonização legislativa na tributação da energia. Os efeitos econômicos desse processo na recuperação europeia foram, como se viu, positivos. 
Para ser procedida a análise dos sistemas tributários dos Estados-partes do Mercosul, da Bolívia, da Venezuela e do Chile, foi firmado um marco teórico tanto sobre a harmonização tributária quanto à tributação do consumo. A partir desse marco, houve a descrição e comparação dos sistemas tributários investigados.

Como soluções, foram propostos mecanismos de harmonização tributária em detrimento de mecanismos de mera coordenação de sistemas tributários. Isso porque, comparando os processos históricos de integração energética da Europa e da América do Sul, concluiu-se que o primeiro, multilateral e intenso, teve maior sucesso do que o segundo, bilateral e esporádico. Ademais, cabe chamar atenção à relevante existência de um espaço de integração na América do Sul: o Mercosul.

Notou-se que o esquema de tributação da energia na maioria dos Estados pesquisados é semelhante: há a tributação geral por intermédio de um IVA e a tributação por um imposto especial geralmente sobre combustíveis e gás natural. A exceção notável é o Brasil, que tem duas incidências gerais - o ICMS e o PIS/Pasep e Cofins - e uma incidência especial, a CIDE-Combustíveis.

Também se destacou na análise dos diferentes sistema tributários a convergência deles na adoção do princípio de destino nas operações internacionais. Isso decorre da constatação de que todos os Estados desonerarem de impostos suas exportações, ou seja, aplicando ajustes fiscais de fronteira, o que é uma característica típica do princípio do destino.

Analisando as estruturas tributárias pesquisadas, foi feito o diagnóstico acerca dos óbices à integração energética. O primeiro problema envolve a múltipla incidência, no caso de produtos de energia, de tributos gerais sobre o consumo, notadamente o ICMS e o PIS/Pasep e Cofins. Essa incidência tanto aumenta o custo em si da energia no país como aumenta o custo de conformidade das empresas. Assim, há uma violação à neutralidade tributária dentro do Mercosul. Além disso, há uma incompatibilidade patente entre esse sistema brasileiro e os demais Estados do Mercosul, que aplicam apenas um tributo geral sobre o consumo, em regra o IVA.

Para esse problema, a modificação legislativa proposta é a unificação da sistemática de tributação geral da energia em um único tributo. A princípio, o problema transcende a questão energética em si, abrangendo, na realidade, a tributação do consumo globalmente considerado. O que se propõe, então, é a unificação da tributação geral do consumo na forma de um IVA. Obviamente, foram destacados os eventuais problemas de caráter fiscal (não tributário) que essa medida possa trazer, dada a dependência dos Estados 
das receitas de ICMS-Energia Elétrica e ICMS-Combustíveis, bem como da vinculação das receitas da contribuição ao PIS/Pasep e Cofins à seguridade social.

A amplitude da reforma e seu efeito financeiro, somadas ao fato de que esse modelo de unificação dependeria de larga reforma constitucional, levaram ao apontamento de uma solução parcial e subsidiária ao problema. Apontou-se, como alternativa à modificação constitucional, a utilização da faculdade prevista no art. $155, \S 4^{\circ}$, inciso IV, da Constituição Federal, para que o Confaz fixe alíquotas uniformes e incidência monofásica do ICMSCombustíveis ou para que o Congresso Nacional aprove lei complementar no mesmo sentido. Nessa hipótese, haveria ao menos alíquotas uniformes do tributo, reduzindo o prejuízo à neutralidade tributária. Contudo, esse caminho não resolveria o problema da tributação redundante pelo PIS/Pasep e Cofins, salvo se sobre essas contribuições fosse criada hipótese de isenção. Esta isenção sobre a energia, por outro lado, importaria em necessidade de medidas de compensação de receita para a seguridade social.

Outro problema identificado na via infraconstitucional é que, embora haja constitucionalmente a previsão de mecanismos de uniformização de alíquotas para o ICMSCombustíveis, o mesmo não há para o ICMS-Energia Elétrica, cujas alíquotas, constatou-se, variam em maior amplitude do que no caso da incidência sobre combustíveis.

Outro óbice à integração energética regional também se mostra centralizado no Brasil. É o fato de o ICMS ser um tributo de caráter subnacional. Isso causa uma disparidade elevada de alíquotas, causando distorções alocativas em matéria de energia. O próprio Brasil, por outro lado, se torna fragmentado no que diz respeito à tributação do consumo, de modo que se dificulta sua integração à região.

A solução proposta a essa questão foi a centralização da tributação do consumo no Brasil. Centralização deve ser entendida como a concentração da competência legislativa para tributação geral do consumo na União. Isso não necessariamente importa que a capacidade tributária, ou seja, competência administrativa arrecadatória e destinação da receita tenham que ser necessariamente federais. Utilizou-se como exemplo o IVA alemão, cuja legislação é nacional, mas com gestão estadual.

O que é relevante é anular as distorções alocativas observadas em razão da violação interna do princípio da neutralidade tributária em matéria de energia. Essa mudança tem caráter constitucional, embora, no que diz respeito especificamente à questão do ICMSCombustíveis, como já exposto, possa ser feita por ato infraconstitucional, a saber, norma do Confaz. Essa medida infraconstitucional, entretanto, não resolveria o problema específico da tributação da energia elétrica. 
Ainda que uniformizado e centralizado no âmbito brasileiro um eventual IVA, nota-se que seus congêneres no Mercosul têm alíquotas díspares. Também na Bolívia, Chile e na Venezuela há variação de alíquotas em relação aos demais países pesquisados. Isso decorre das necessidades fiscais de cada Estado soberano. O sistema de seguridade social do Uruguai, por exemplo, tem forte dependência da tributação sobre o consumo. A uniformização nas alíquotas regionais - especialmente nos Estados-partes do Mercosul - é imprescindível à neutralidade tributária, pois permitirá a equalização dos custos de investimento no bloco.

Os tributos especiais sobre o consumo da energia podem ser utilizados como instrumentos para uniformizar a carga tributária incidente sobre a energia no bloco, notadamente em matéria de combustíveis. A elevação ou redução das alíquotas desses tributos especiais pode ser utilizada para neutralizar os efeitos de alíquotas desequiparadas de IVA. Ademais, é importante observar que o caráter monofásico dos tributos especiais sobre o consumo de combustíveis facilita a aferição do peso tributário sobre o os produtos, o que favorece seu uso como meio de harmonização por instrumentação.

Quanto à adoção dos princípios de origem e destino na tributação da energia, assentou-se, com base no marco teórico adotado, que o critério de origem é o que melhor promove a integração regional, pois a adoção desse princípio elimina a necessidade de ajustes fiscais de fronteira (e das próprias fronteiras fiscais, por consequência) e permite uma efetiva livre circulação de bens e serviços em um espaço de integração. Como foi examinada a integração energética no espaço do Mercosul, a discussão sobre a adoção de princípios jurisdicionais tributários no comércio internacional também se mostra relevante.

A problemática dos princípios de origem e destino abarca a discussão tanto da tributação geral quanto especial sobre o consumo. Dessa forma, a problemática tem que ser encarada de acordo com cada espécie de tributo. Isso porque a tributação geral normalmente se dá por tributos plurifásicos e não-cumulativos, enquanto a tributação especial ocorre normalmente mediante tributos monofásicos. No caso dos países pesquisados, a tributação especial ocorre normalmente na importação ou na primeira venda no mercado interno.

A esse respeito, concluiu-se pela manutenção do princípio de destino na tributação da energia. Foi suscitada a existência de literatura sobre o chamado princípio de origem restrito, em que é adotado o princípio de origem apenas em relação aos espaços integrados, enquanto se mantém a adoção do princípio de destino quanto aos Estados estranhos ao referido bloco.

A tributação de produtos de energia na origem, contudo, ainda que em espações em processo de integração, pode gerar um incremento das receitas tributárias no Estado 
explorador em detrimento do Estado consumidor. Este último, inclusive, suportará parte do passivo ambiental decorrente do consumo de energia, como a poluição do ar em virtude da queima de derivados de petróleo.

Há também a questão da soberania energética em face da segurança energética propriamente dita. Ainda que determinados Estados se situem em um espaço de integração, a tributação na origem mitiga a possibilidade do Estado consumidor regular a dependência da sua matriz energética em relação ao vizinho exportador. Ocorre, assim, uma verdadeira mitigação da soberania energética de um Estado em processo de integração em prol da segurança propriamente dita.

Ademais, adotar o princípio de origem em tributos especiais implicaria em retirar do Estado importador a competência regulatória por tributação extrafiscal. Dessa forma, ficaria com o Estado exportador o poder de delimitar os termos da política energética do Estado importador, em franco prejuízo da soberania energética deste.

O presente trabalho buscou analisar as diferentes modalidades de tributação da energia nos sistemas tributários selecionados da América do Sul e propor alterações legislativas no sistema tributário brasileiro que promovam a harmonização do mesmo com os demais sistemas tributários da América do Sul. Notou-se a existência de peculiaridades sistêmicas que não são de forma alguma inconciliáveis. Na verdade, o que se notou é uma aproximação já existente entre os modelos de tributação da energia. A exceção notável do Brasil, a economia mais relevante da região, se mostra um óbice à integração energética regional.

Boa parte dos problemas identificados no sistema de tributação da energia não são de forma alguma dele exclusivos. Contudo, a relevância da energia como insumo de produção é inquestionável. Espera-se, portanto, que a discussão específica sobre a tributação da energia conte com relevância tal que possa servir como "ponta de lança" na reforma do sistema de tributação do consumo no Brasil.

Embora não seja este o espaço para essa discussão, as grandes reformas de sucesso nascem de mudanças pontuais, contínuas, graduais e duradouras. Espera-se que, com a pequena contribuição feita nestas páginas, possa ser dado um passo a mais em prol da reforma justa e eficiente do sistema tributário brasileiro. 


\section{BIBLIOGRAFIA}

ARGENTINA. Ley $n^{\circ} 23.966$, de $1^{\circ}$ de agosto de 1991. Financiamiento del Régimen Nacional de Previdencia Social. Afectación del I.V.A. Impuesto sobre Combustibles Líquidos y Gas Natural. Modificaciones a la Ley del Fondo Nacional de la Vivienda. Derogación de Regímenes de Jubilaciones Especiales. Impuesto sobre los bienes personales no incorporado al proceso económico. Destino de los recursos de las privatizaciones. Modificación de la ley de las tasas judiciales. Disponível em: http://servicios.infoleg.gob.ar/infolegInternet/anexos/04999/365/texact.htm, acessado em 8 de dezembro de 2016, às 14h.

ARGENTINA. Decreto $n^{\circ} 280$, de 1997. Apruébase el texto ordenado de la Ley de Impuesto al Valor Agregado, sustituido por el artículo $1^{\circ}$ de la Ley $\mathrm{N}^{\circ} 23.349$ y sus modificaciones. Disponível em Infoleg: http://servicios.infoleg.gob.ar/infolegInternet/anexos/4000044999/42701/texact.htm, acessado em 8 de dezembro de 2016, às 14h.

ARGENTINA. Comisión de Planificación y Coordinación Estratégica del Plan Nacional de Inversiones Hidrocarburíferas. Resolución $n^{0} 35 / 2015$. Sustitúyese el Artículo $1^{\circ}$ de la Resolución $N^{\circ} 34$ de fecha 11 de marzo de 2015 de la Comisión de Planificación y Coordinación Estratégica del Plan Nacional de Inversiones Hidrocarburífera. Disponível em: http://servicios.infoleg.gob.ar/infolegInternet/anexos/240000-244999/244969/norma.htm, acessado em 22 de dezembro de 2016, às $15 \mathrm{~h}$.

ASSOCIAÇÃO BRASILEIRA DE DISTRIBUIDORAS DE ENERGIA ELÉTRICA ABRADEE. Mapa de alíquotas de ICMS. Disponível em http://www.abradee.com.br/financeiro/mapas-aliquotas-icms/residencial, acessado em 14 de outubro de 2016 , às $14 \mathrm{~h} 26 \mathrm{~min}$.

BACHUR, João Paulo. Federalismo fiscal, atribuições fiscais constitucionais e equalização regional: EUA, Alemanha e Brasil em perspectiva comparada. Revista Serviço Público, Brasília, 56 (4), p. 377-401, out/dez 2005.

BASTO, José Guilherme Xavier de. Cadernos de ciência e técnica fiscal: a tributação do consumo e sua coordenação internacional. n. 164. Lisboa: Centro de Estudos Fiscais, 1991.

BASTOS, Celso Ribeiro. Curso de direito constitucional. 7. ed. São Paulo: Saraiva, 1984.

BEAUMONT, Pierre de. Harmonisation des fiscalités européennes - l'impot sur l'energie. Paris: Librarie Générale de Droit et de Jurisprudence, 1955.

BORDIN, Luís Carlos V. LAGEMANN, Eugênio. Formação tributária do Brasil : a trajetória da política e da administração tributária. Porto Alegre: Fundação de Economia e Estatística Sigfried Emanuel Heuser, 2006.

BRASIL. Consultoria-Geral da União. Parecer FC-27. Não cabe cobrar tributos sobre faturamento da ITAIPU BINACIONAL, por força do Tratado firmado entre o Brasil e o Paraguai, no dia 26.4.73. Publicado no D.O.U. em 9 de maio de 1994, p. 6.814.

BRASIL. Agência Nacional de Energia Elétrica - ANEEL. Atlas de energia elétrica no Brasil. Brasília: ANEEL, 2005. 
BRASIL. Ministério das Minas e Energia. Plano Nacional de Eficiência Energética. Brasília: Ministério das Minas e Energia, 2011.

BRASIL. Agência Nacional de Energia Elétrica - ANEEL. Relatório ANEEL 2012. Brasília: ANEEL, 2013.

BRASIL. Receita Federal do Brasil. Carga Tributária no Brasil 2015. Brasília: Ministério da Fazenda, 2016a.

BRASIL. Conselho Nacional de Política Fazendária. Boletim do ICMS. Disponível em https://www.confaz.fazenda.gov.br/legislacao/boletim-do-icms, acessado em 11 de outubro de $2016 \mathrm{~b}$, às $15 \mathrm{~h} 30 \mathrm{~min}$.

BRASIL. Conselho Nacional de Política Fazendária. Alíquotas do ICMS. Disponível em https://www.confaz.fazenda.gov.br/legislacao/aliquotas-icms-estaduais, acessado em 20 de outubro de $2016 \mathrm{c}$, às $18 \mathrm{~h}$.

CAMARGO, Guilherme Bueno. A guerra fiscal e seus efeitos : autonomia x centralização. In: CONTI, José Maurício (Org.). Federalismo fiscal. São Paulo: Manole, 2004. p. 191-222.

CARRAZA, Roque Antônio. ICMS. 12. ed. São Paulo: Malheiros, 2007.

CHILE. Decreto ${ }^{\circ}{ }^{825}$, de 1974. Ley sobre Impuesto a las Ventas e Servicios. Publicado no Diário Oficial de 30 de novembro de 1976.

CHILE. Ley $n^{0}$ 18.502. Establece impuestos a los combustibles que señala. Publicado no Diário Oficial de 4 de agosto de 2013.

CONGRESSO NACIONAL, 44a Legislatura, 1971, vol. 5. Palácio do Congresso Nacional. Anais... Brasília: Editora do Senado, 1971.

D’ARAÚJO, Pedro Júlio Sales; PAULINO, Sandra Regina da Fonsêca; GASSEN, Valcir. Tributação sobre o consumo: o esforço em onerar mais quem ganha menos. In: GASSEN, Valcir (org.). Equidade e eficiência da matriz tributária brasileira: diálogos sobre Estado, Constituição e Direito Tributário. Brasília: Consulex, 2012. p. 283-316.

DERZI, Misabel Abreu Machado. A necessidade de instituição do IVA no sistema constitucional brasileiro. In: BALTHAZAR, Ubaldo Cesar (org.). Reforma tributária e MERCOSUL. Belo Horizonte: Del Rey, 1998. p. 17-30.

DIAS, Abel Alexandre Vilaça. O sistema comum do IVA: a harmonização do IVA na União Europeia e a importância do princípio da tributação na origem. Tese de Doutorado em Direito Fiscal apresentada à Faculdade de Direito da Universidade do Porto. Porto, 2005.

ELALI, André. Incentivos fiscais, neutralidade da tributação e desenvolvimento econômico : a questão da redução das desigualdades regionais e sociais. In: ELALI, André; MARTINS, Ives Gandra da Silva; PEIXOTO, Marcelo Magalhães (Org.). Incentivos fiscais : questões pontuais nas esferas federal, estadual e municipal. São Paulo: MP Ed, 2007. p. 37-66.

Algumas ponderações a respeito da concorrência fiscal internacional. In: MARTINS, 
Ives Grandra da Silva et all. Temas de tributação e direito internacional. São Paulo: MP Ed, 2008. p. 37-87.

ENERGY CHARTER SECRETARIAT - ECS. The Energy Charter Treaty and Related Documents. Bruxelas: Energy Charter Secretariat, 2004.

FARIA, Luiz Alberto Gurgel de. A extrafiscalidade e a concretização do princípio de redução das desigualdades regionais. São Paulo: Quartier Latin, 2010.

FEDERAÇÃO DAS INDÚSTRIAS DO ESTADO DO RIO DE JANEIRO - FIRJAN. Nota técnica: A perspectiva de renovação das concessões, a redução de encargos e tributos e o impacto sobre o custo da energia elétrica para a indústria no Brasil. Disponível em: http://www.firjan.org.br/data/pages/2C908CE9215B0DC40121793A0FCE1E51.htm. Acessado em 25/08/2014, às $12 \mathrm{~h} 30 \mathrm{~min}$.

FEDERAÇÃO DAS INDÚSTRIAS DO ESTADO DE SÃO PAULO - FIESP. The regulation of international trade energy - fuel and electricity. São Paulo: FIESP, 2013.

FERNANDES, Edson Carlos. Sistema tributário do MERCOSUL : o processo de harmonização das legislações tributárias. 3. ed. São Paulo: Editora Revista dos Tribunais, 2001 .

FIGUEIREDO, Leonardo Vizeu. Lições de direito econômico. 7. ed. Rio de Janeiro: Forense, 2014.

FUNDACIÓN DE INVESTIGACIONES ECONÓMICAS LATINOAMERICANAS - FIEL. Documento de trabajo $\mathbf{n}^{\mathbf{0}} \mathbf{1 3}$ - El sistema tributario argentino. Análisis y evaluación de propuestas para reformarlo. Buenos Aires: FIEL, 2015.

FUNDACIÓN JUBILEO. Serie Debate Público n⿳0 29 - el sistema tributario en Bolivia : análisis y propuestas para una reforma. La Paz: Fundación Jubileo, 2013.

GASSEN, Valcir. A tributação do consumo: o princípio de origem e destino em processos de integração econômica. 2. ed. São Paulo: Saraiva, 2013.

GRAU, Eros Roberto. A ordem econômica na Constituição de 1988. 13. ed. São Paulo: Atlas, 2008.

GUANIPA, Henry Jiménez. A integração energética na América do Sul : realidade ou utopia? A Constituição europeia como referência. In: GARÍN, A. L. LAMY, M. GASPAR, Renata. Direito energético : desafios e perspectivas ambientais e internacionais. São Paulo: Editora Universitaria Leopoldianum, 2013. p. 45-78.

LAGEMANN, Eugênio. Há necessidade de um imposto único sobre o consumo no âmbito do Mercosul? In: BALTHAZAR, Ubaldo Cesar (org.). Reforma tributária e MERCOSUL. Belo Horizonte: Del Rey, 1998. p. 179-190.

. Tributação: seu universo, condicionantes, objetivos, funções e princípios. In:

GASSEN, Valcir (org.). Equidade e eficiência da matriz tributária brasileira: diálogos sobre Estado, Constituição e Direito Tributário. Brasília: Consulex, 2012. p. 51-70. 
LEONETTI, Carlos Araújo. A harmonização tributária no MERCOSUL e a necessidade de instituição de um IVA federal no Brasil. Interesse Público, Belo Horizonte, v. 9, n. 46, nov. 2007.

MALHÃES, José; SALOMÃO, Luiz. Processo de integração energética: rumos e percalços. In: Observatório Político Sul-Americano e Núcleo de Estudos sobre o Congresso - Papéis Legislativos. Brasília: Senado Federal, 2007.

MARINHO, Rodrigo César de Oliveira. Intervenção no domínio econômico: a contribuição e seu perfil constitucional. São Paulo: Fórum, 2011.

ORGANIZAÇÃO PARA COOPERAÇÃO E DESENVOLVIMENTO ECONÔMICO OCDE. Background note: regulated conduct defense. Paris: OECD Publishing, 2011.

Consumption Tax Trends 2016: VAT/GST and excise rates, trends and policy issues. Paris: OECD Publishing, 2016.

PARAGUAI. Ley n ${ }^{0} 125$, de 1991. Establece el Nuevo Régimen Tributario. Disponível em http://www.hacienda.gov.py/normativa/Ley\%20125-

1991\%20Que\%20establece\%20el\%20Nuevo\%20Régimen\%20Tributario.pdf, acessado em 23 de dezembro de 2016, às $10 \mathrm{~h}$.

PIQUET, Rosélia. Os elos entre petróleo e região. In: PIQUET, Rosélia; SERRA, Rodrigo (org.). Petróleo e região no Brasil: o desafio da abundância. Rio de Janeiro: Garamond, 2007. p. 15-34.

PORTO, Ricardo Philippi. Os princípios tributários e a harmonização fiscal no MERCOSUL. São Paulo: Scortecci, 2011.

SALDANHA, Eduardo. Harmonização legislativa tributária no MERCOSUL e na União Europeia. Curitiba: Juruá, 2008.

SÁNCHEZ, Ángel Sánchez. EI IVA en las operaciones intracomunitarias. Madri: Eidicones Desto S.A., 1999.

SERRA, Rodrigo. Concentração espacial das rendas petrolíferas e sobrefinanciamento das esferas de governo locais. In: PIQUET, Rosélia; SERRA, Rodrigo (org.). Petróleo e região no Brasil: o desafio da abundância. Rio de Janeiro: Garamond, 2007. p. 77-109.

UDAETA, Miguel Edgar Morales et all. Ponderação analítica para a integração energética da América do Sul. Revista Brasileira de Energia, vol. 12, nº 2, p. 1-19, 2006.

URUGUAI. Guia do Investidor - aspectos tributários. Montevidéu: Uruguay XXI, 2015.

URUGUAI. Decreto ${ }^{\circ}$ 96, de 21 de fevereiro de 1990. Regulamento do IMESI. Disponível em: http://www.dgi.gub.uy/wdgi/agxppdwn?6,4,213,O,S,0,7987;S;21;877, acessado em 24 de dezembro de 2016, às 16h. 
VALADÃO, Marcos Aurélio Pereira. Intervenção no domínio econômico e tributação: extrafiscalidade - aspectos. Estudos de direito público: homenagem aos 25 anos do mestrado em direito da UNB, p.223-248, 2000.

VASCONCELLOS, Marco Antônio Sandoval de. Economia: micro e macro. 4. ed. São Paulo: Atlas, 2006.

VENEZUELA. Decreto con fuerza de ley orgánica de hidrocarburos. Gaceta Oficial $\mathrm{n}^{\circ}$ 37.323, em 13 de novembro de 2001.

VENEZUELA. Decreto ${ }^{0} 1.436$, de 17 de novembro de 2014. Decreto con rango, valor e fuerza de ley de reforma de la ley que establece el Impuesto al Valor Agregado. Gaceta Oficial $n^{0} 6.152$ Extraordinária, 18 de novembro de 2014.

WORLD ENERGY COUNCIL - WEC. Regional energy integration in Latin America and the Caribbean. Londres: World Energy Council, 2008. 